University of Nebraska - Lincoln

DigitalCommons@University of Nebraska - Lincoln

2012

\title{
Surface state engineering of molecule-molecule interactions
}

\author{
Geoffrey Rojas \\ University of Nebraska-Lincoln, geoff.rojas@gmail.com
}

Scott Simpson

State University of New York at Buffalo, ssimpson@sbu.edu

Xumin Chen

University of Nebraska-Lincoln, xuminche@unlserve.unl.edu

Donna A. Kunkel

University of Nebraska-Lincoln, donna.ann.kunkel@gmail.com

Justin Nitz

University of Nebraska-Lincoln, jnitz3@hotmail.com

See next page for additional authors

Follow this and additional works at: https://digitalcommons.unl.edu/physicsenders

Part of the Physics Commons

Rojas, Geoffrey; Simpson, Scott; Chen, Xumin; Kunkel, Donna A.; Nitz, Justin; Xiao, Jie; Dowben, Peter A.; Zurek, Eva; and Enders, Axel, "Surface state engineering of molecule-molecule interactions" (2012). Axel Enders Publications. 31.

https://digitalcommons.unl.edu/physicsenders/31

This Article is brought to you for free and open access by the Research Papers in Physics and Astronomy at DigitalCommons@University of Nebraska - Lincoln. It has been accepted for inclusion in Axel Enders Publications by an authorized administrator of DigitalCommons@University of Nebraska - Lincoln. 


\section{Authors}

Geoffrey Rojas, Scott Simpson, Xumin Chen, Donna A. Kunkel, Justin Nitz, Jie Xiao, Peter A. Dowben, Eva Zurek, and Axel Enders 


\title{
Surface state engineering of molecule-molecule interactions
}

\author{
Geoffrey Rojas, ${ }^{1}$ Scott Simpson, ${ }^{2}$ Xumin Chen, ${ }^{1}$ Donna A. Kunkel, ${ }^{1}$ Justin Nitz, \\ Jie Xiao, ${ }^{1}$ Peter A. Dowben, ${ }^{1}$ Eva Zurek, ${ }^{2}$ and Axel Enders ${ }^{1}$ \\ 1. Department of Physics and Astronomy, University of Nebraska-Lincoln, Lincoln, NE 68588, USA \\ 2. Department of Chemistry, State University of New York at Buffalo, Buffalo, NY 14260-3000, USA \\ Corresponding author - A. Enders, email axel@unl.edu
}

\begin{abstract}
Engineering the electronic structure of organics through interface manipulation, particularly the interface dipole and the barriers to charge carrier injection, is of essential importance to improve organic devices. This requires the meticulous fabrication of desired organic structures by precisely controlling the interactions between molecules. The well-known principles of organic coordination chemistry cannot be applied without proper consideration of extra molecular hybridization, charge transfer and dipole formation at the interfaces. Here we identify the interplay between energy level alignment, charge transfer, surface dipole and charge pillow effect and show how these effects collectively determine the net force between adsorbed porphyrin $2 \mathrm{H}-\mathrm{TPP}$ on $\mathrm{Cu}(111)$. We show that the forces between supported porphyrins can be altered by controlling the amount of charge transferred across the interface accurately through the relative alignment of molecular electronic levels with respect to the Shockley surface state of the metal substrate, and hence govern the self-assembly of the molecules.
\end{abstract}

\section{Introduction}

The electronic properties of organics in contact with metal substrates depend on the alignment of the electronic levels and bands at the metal-organic interface and the resulting hybridization of states, as well as charge transfer to or from the adsorbate, the molecular band offsets, ${ }^{1-3}$ the emergence of interaction-induced states, ${ }^{4,5}$ the distortion of the molecules ${ }^{6}$ as well as changes that may occur at the substrate surface. ${ }^{7}$ Also key to the interface electronic structure is the presence of substrate surface states. ${ }^{8}$ Generally, the properties of metal-organic interfaces are determined by a delicate balance of competing factors and experiments usually assess only the cumulative effect of many different contributions to the interface electronic structure. ${ }^{6,7}$ The net charge transferred across the interface, the formation of charge dipoles, and the work function are intrinsically related effects. Often what is highlighted is the interface dipole or the work function, but the substrate surface states, a fundamental ingredient to the interface electronic structure, are often poorly described. Here we demonstrate the importance of the Shockley surface states ${ }^{9}$ in establishing the interface electronic structure using the example of tetraphenyl porphyrins (2H-TPP) chemisorbed on $\mathrm{Cu}(111)$. The surface state interactions with the adsorbed molecular layers are important for the charge transfer between the substrate and the molecule and the resulting surface dipoles that ultimately strongly influence the intermolecular lateral interactions. The surface state can be shifted in energy by using Ag buffer layers of varied thickness on $\mathrm{Cu}(111)$, thereby determining the overlap of molecular levels with substrate surface metal bands, ${ }^{2}$ the amount of charge transferred, and consequently the intermolecular forces. We can relate our findings to the observed strong repulsive intermolecular Coulomb forces and the repression of molecular self-assembly. We show that the molecule-molecule interactions can be changed from repulsive to attractive, a concept similar to the steering of the molecular growth via dipolar interaction. ${ }^{37,38}$ What is new here is that this is achieved without chemical modification of the molecules, but rather by controlling the amount of charge transferred across the interface through surface state engineering using Ag buffer layers on the $\mathrm{Cu}(111)$.

\section{Results and discussion}

The 2D character of an adsorbed monolayer of $2 \mathrm{H}-\mathrm{TPP}$ has been exploited for a comparative study of the occupied and unoccupied band structure of large ensembles with direct and inverse photoelectron spectroscopy (UPS and IPES), as well as of selected individuals with the tip of a scanning tunneling microscope (STM) in the local spectroscopy mode (STS). By this combination of local and area-integrating complementary methods the atomistic basis of observed features in the electronic structure became evident. STM images, taken at sub-monolayer to monolayer coverage of $2 \mathrm{H}-\mathrm{TPP}$ on $\mathrm{Cu}(111)$, are shown in Figure 1 . A coverage of $\theta$ $=1 \mathrm{ML}$ is defined here as the maximum observed packing density within the first layer of 0.42 molecules per $\mathrm{nm}^{2}$. This 

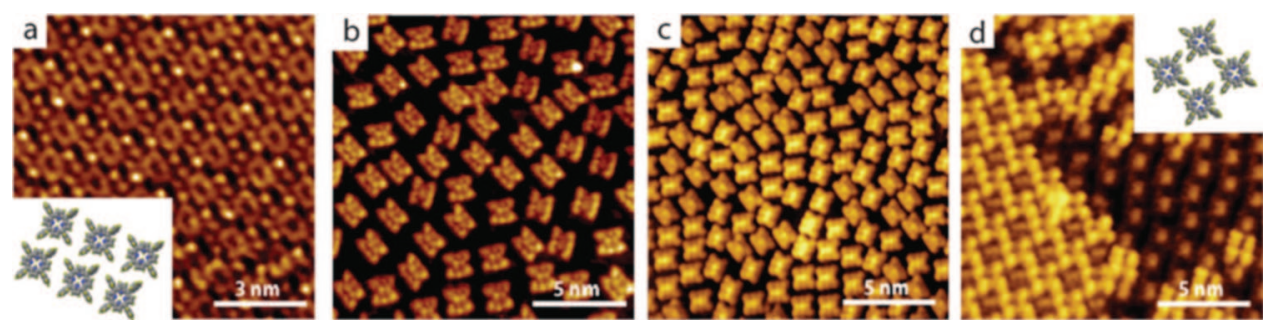

Figure 1. STM images of $2 \mathrm{H}-\mathrm{TPP}$ on $\mathrm{Ag}(111)(\mathrm{a})$ and $\mathrm{Cu}(111)(\mathrm{b}-\mathrm{d})$. The molecule coverage is $0.6 \mathrm{ML}(\mathrm{b}), 0.7 \mathrm{ML}(\mathrm{c})$ and $1.2 \mathrm{ML}(\mathrm{d}) . I_{\mathrm{t}}=0.4 \mathrm{nA}$, $U_{\mathrm{b}}=+0.8 \mathrm{~V}$.

packing is $20 \%$ smaller, expressed in terms of areal density, than that observed on $\operatorname{Ag}(111)$, see Figure 1a. ${ }^{10,11}$ The mobility of the molecules is sufficiently high for surface diffusion, as concluded from visible substrate step edge decoration (not shown), however, no island nucleation is observed. The molecules remain isolated and roughly equally spaced on the terraces of the $\mathrm{Cu}(111)$ (Figure $1 \mathrm{~b} \& \mathrm{c}$ ). They appear to be aligned along the three $\langle 110\rangle$ crystallographic directions of the surface, concluded from the observed angles of multiples of $120^{\circ}$ between the major axes of any two molecules. ${ }^{38}$ It can be seen by comparing Figure $1 \mathrm{~b}$ and $\mathrm{c}$ that molecules are added to the first monolayer even if the gaps between the molecules are significantly smaller than the size of the molecules itself. This requires rearrangement of all molecules in the layer during deposition. Self-organization of the 2H-TPPs into networks, as found for the same molecules on $\mathrm{Ag}(111)$ in Figure $1 \mathrm{a}$ and $\mathrm{Au}(111),{ }^{10-12}$ was not observed on $\mathrm{Cu}(111)$ at any coverage and sample temperature in the range between $77 \mathrm{~K}$ and $500 \mathrm{~K}$. We do observe by inspection of Figure $1 \mathrm{c}$ and $\mathrm{d}$, however, a behavior like in the case of a two-dimensional gas where the average intermolecular distance decreases with increasing coverage. ${ }^{40}$ Also, an alignment of the molecules relative to each other sets in as the areal density of the molecules increases. Upon reaching saturation coverage within the first layer, molecules nucleate into islands on top of the first layer. The architecture of this arrangement is a porous 2D network apparently dominated by $\Pi-\Pi$ bonds, and is a different architecture than the densely packed arrangement observed for the same molecules on $\mathrm{Ag}(111)$ in Figure 1a. We conclude from these observations that the net force between the molecules within the first layer is repulsive, while it is attractive for the molecules within the second layer.

The occupied and unoccupied electronic structure of the adsorbate-substrate system has been studied in detail with tunneling spectroscopy and combined photoemission and inverse photoemission spectroscopies, as seen in Figure 2. The combined photoemission spectra of the 2H-TPP covered $\mathrm{Cu}(111)$ show characteristic peaks that are not observable in the spectra of the pristine $\mathrm{Cu}(111)$. One feature, at $+2 \mathrm{eV}$, is in reasonable agreement with the lowest unoccupied molecular orbital (LUMO) of calculated and measured spectra for similar TPP systems. ${ }^{13}$ Also the spectra of the occupied states resemble those reported for 2H-TPP adsorbed on other noble-metal systems, ${ }^{14}$ with the highest occupied molecular orbital (HOMO) at approximately $-2 \mathrm{eV}$. Within this HOMOLUMO gap we observe an additional characteristic peak at $+0.65 \mathrm{eV}$ at sub-monolayer coverage, which is observed to decay rapidly in intensity with increasing coverage and is not apparent in the spectra at 3 ML coverage or more.

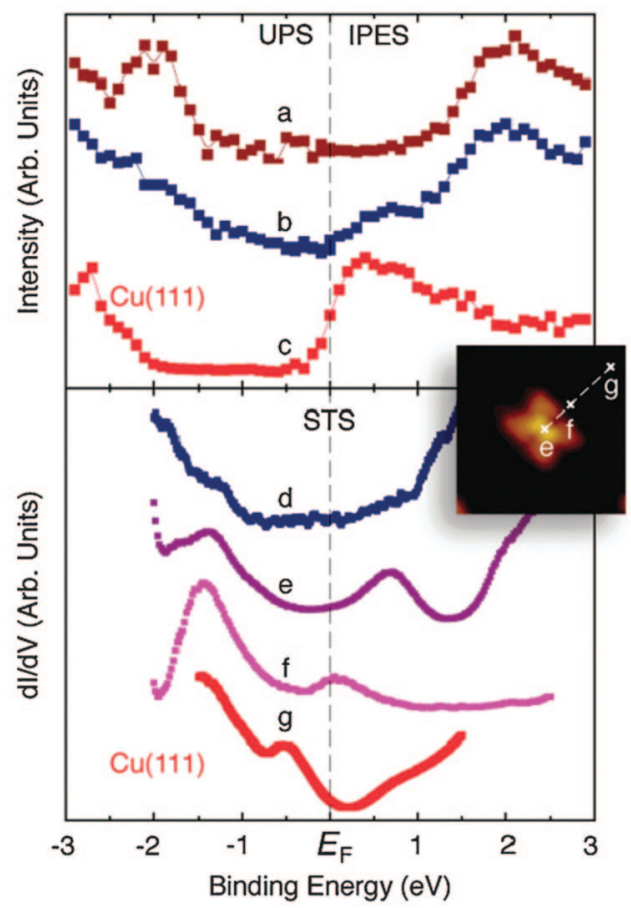

Figure 2. Upper panel: Photoemission (UPS) and inverse photoemission (IPES) spectra of 2H-TPP on Cu(111). (a) 3 ML 2H-TPP; (b) 1 ML 2H-TPP; (c) bare $\mathrm{Cu}(111)$. Lower panel: STS point spectra taken on or near lone TPP molecules. (d) On top of a molecule in the second layer; (e) on top of a molecule in the first layer; (f) on $\mathrm{Cu}$, at a distance of 1 Angstrom from the molecule edge; (g) on $\mathrm{Cu}$, several Angstroms away from a molecule. Inset: STM image showing the positions where spectra (e-g) were taken. Binding energies are denoted as $E-E_{\mathrm{F}}$ making occupied state energies negative and unoccupied states positive.

Complementary to the combined photoemission and inverse photoemission spectroscopy measurements, point spectroscopy measurements have been taken locally with STS over a similar energy range, see bottom panel in Figure 2. Single point $d I / d V$ spectra were taken over the molecules themselves, as well as the surrounding $\mathrm{Cu}$ surface at successively increasing distance from the molecule center. The observed HOMO and LUMO of the molecules are aligned well with those observed using photoelectron spectroscopy; the LUMO is seen at approx. $1.5 \mathrm{eV}$ above the Fermi level, contained with the LUMO+1 peak. The spectra taken on the bare $\mathrm{Cu}$ show the well-known Shockley surface state at -0.4 $\mathrm{eV}^{15,16}$ which is not resolved in the photoelectron spectra. This surface state is suppressed on the $\mathrm{Cu}$ surface covered with $\theta \geq 0.7 \mathrm{ML} 2 \mathrm{H}-\mathrm{TPP}$. At lower coverage, this surface state is shifted towards the Fermi level in the direct vicinity of the 
molecule. The spectra shown in Figure $2 \mathrm{f}$ were taken at a distance of $6 \AA$ from the molecule center and show this surface state shifted upward in energy by $\Delta E \approx 0.4 \mathrm{eV}$. Also within the HOMO-LUMO gap at $+0.65 \mathrm{eV}$ an electronic state, already known from the IPES measurements, is observed at the molecules. This peak is only observed for spectra taken of molecules in the first monolayer. Spectra taken of molecules in the second layer do not show this substrate surface state feature, and yet the characteristic LUMO and HOMO remain undisturbed.

The molecules of the second layer appear in the STM images under the same tunneling conditions with dark center and bright phenyl arms, while in the first layer the opposite is observed, the centers are bright and the phenyl arms are dark. This change in contrast is due to an electronic level rearrangement at the interface. ${ }^{5}$ We again exploit the local nature of tunnel spectroscopy to identify local differences in the DOS. In STS point spectra taken at the center of a molecule in the second layer the new peak at $+0.65 \mathrm{eV}$, observed over the molecules in the first layer, does not appear. This allows us to attribute the physical origin of this state to the $2 \mathrm{H}-\mathrm{TPP} / \mathrm{Cu}$ interface. The electronic states in this energy range have been observed previously for other porphyrinbased surface systems on $\mathrm{Ag}(111)$ as well as $\mathrm{Cu}(111)$ with photoelectron spectroscopy, 5,17,18 and have been heretofore ascribed to the shifted LUMO of the porphyrin macrocycle. However, the absence of the energy state at $+0.65 \mathrm{eV}$ in the second monolayer provides now evidence that this state is an interface state.

Measurements of the local work function, $\Phi$, have also been made using the STM. We have characterized and measured the local work function to evaluate the local surface dipoles, following a procedure similar to that published in Reference 19 and described in the Supplementary Information. The so measured work function of the $\mathrm{Cu}(111)$ is $\Phi_{\mathrm{Cu}}$ $=(4.9 \pm 0.2) \mathrm{eV}$. With $2 \mathrm{H}-\mathrm{TPP}$ deposited, we find a decrease of the work function by $\Delta \Phi \approx(-2.0 \pm 0.5) \mathrm{eV}$ over the center of TPP molecules, and an increase of $\Delta \Phi \approx+(1.0 \pm 0.4) \mathrm{eV}$ at the boundary of the molecule's macrocycle. While these data are in quantitative agreement with the net work function shift of $0.84 \mathrm{eV}$ found for $1 \mathrm{ML} 2 \mathrm{H}-\mathrm{TPP}$ on $\mathrm{Ag}(111)^{5}$, the particular advantage of these local measurements is that they reveal a significant amount of spatial variance. For clarification of the spatial variance, a map of the work function has been measured in a square area across the molecule and its surrounding from $100 \times 100$ separately performed point spectra. This $\Phi$-map is shown together with an STM image of a lone $2 \mathrm{H}$ TPP on $\mathrm{Cu}(111)$ in Figure 3. By comparing both results in this manner the spatial dependence of the work function can be associated with local chemical components of the adsorbed molecule, and with the locally measured density of states. The $\Phi$ drops significantly over the location of the central pyrolines while increasing relatively to the bare $\mathrm{Cu}(111)$ over the surrounding hydrogen edges and phenyl ligands. Surrounding the molecule in a narrow band there is a slight drop in the $\mathrm{Cu}(111)$ work function. This band corresponds to the area where the upward shift in the surface state was observed, too.

The electronic interactions at the $2 \mathrm{H}-\mathrm{TPP} / \mathrm{Cu}$ and the $2 \mathrm{H}-$ $\mathrm{TPP} / \mathrm{Ag}$ interfaces can be understood using the results of dispersion corrected density functional theory (DFT-D) calculations, undertaken as described in the Supplementary
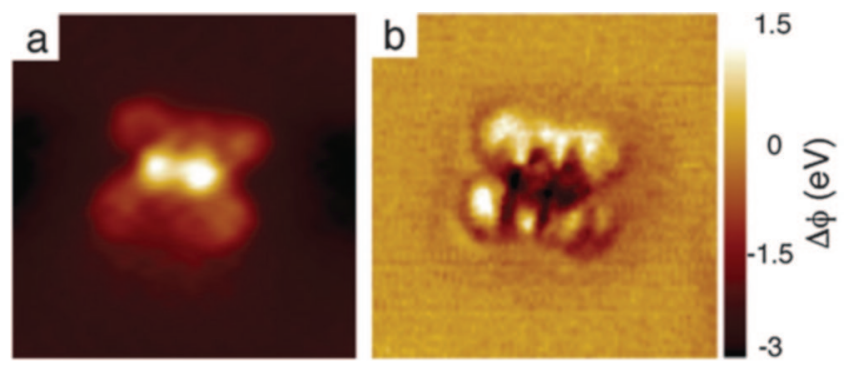

Figure 3. (a) STM image of a lone $2 \mathrm{H}-\mathrm{TPP}$ molecule on $\mathrm{Cu}(111) \cdot I_{\mathrm{T}}=$ $0.4 \mathrm{nA}, U_{\mathrm{b}}=+0.8 \mathrm{~V}$; image size $4 \mathrm{~nm} \times 4 \mathrm{~nm}$. (b) Work function map of the same molecule, showing lowered work function at the center of the molecule and increased work function at the boundary of the molecule, relative to the substrate.

Table 1 The binding energy $\left(E_{\mathrm{b}}\right)$, charge and structure of 2H-TPP on top of $\mathrm{Cu}(111)$ and $\mathrm{Ag}(111)$. The surface distances, $d_{\mathrm{Cu}}$ and $d_{\mathrm{Ag}^{\prime}}$ are the average calculated distances of the central nitrogen atoms of the $2 \mathrm{H}$-TPP to the metal. The dihedral angle is the angle with respect to the macrocycle, and is defined in the Supplementary Information.

\begin{tabular}{lllll}
\hline System & $E_{\mathrm{b}} / \mathrm{eV}$ & $\begin{array}{l}\text { Surface } \\
\text { charge }\end{array}$ & $\begin{array}{l}\text { Dihedral } \\
\text { angle } /{ }^{\circ}\end{array}$ & $\begin{array}{l}\text { Surface } \\
\text { distance, } d / \AA\end{array}$ \\
\hline $\mathrm{Cu}(111)$ & 5.31 & -0.89 & 38.3 & 3.05 \\
$\mathrm{Ag}(111)$ & 3.07 & -0.46 & 42.1 & 3.30 \\
\hline
\end{tabular}

Information. The computational results, summarized in Table 1 , show that the binding energy of the molecules to the substrate is significantly larger on $\mathrm{Cu}(111)(5.31 \mathrm{eV})$ than on $\mathrm{Ag}(111)(3.1 \mathrm{eV})$, resulting in a shorter distance between the molecule and the substrate and increased distortion of the molecule on $\mathrm{Cu}(111)$ (Figure 4). The latter number is in good agreement with the $2.8 \mathrm{eV}$ computed using the mixed Gaussian plane wave scheme. ${ }^{45}$ In particular, the dihedral angle of the phenyl ligands changes and the ligands become nearly planar to the surface. For comparison, we calculate the free 2H-TPP molecule as having a dihedral angle of $62.7^{\circ}$, in agreement with ref. 10, 20-22 and 45 . This distortion is visible in the STM images in Figure 1b, and in agreement with recently reported results. ${ }^{39,41}$ As a result of the rotation of the phenyl arms, the pyrrole rings containing the N-H motifs distort downwards so that the shortest distance between one of their carbons and the surface is 2.62/2.86 $\AA$ for $\mathrm{Cu}$ / $\mathrm{Ag}$. The pyrrole rings containing the lone or iminic nitrogen atoms distort upwards and the largest distance between one of their carbons and the surface is 4.10/4.25 $\AA$ for $\mathrm{Cu}$ / $\mathrm{Ag}$. The dispersion interaction was calculated to be greater between $2 \mathrm{H}$-TPP and $\mathrm{Cu}(111)$ than with $\mathrm{Ag}(111)$ (9.2 vs. 5.7 $\mathrm{eV})$, and - as shown in the Supplementary Information-so were other contributions to the binding energy.

The composition of the molecular orbitals of the metaladsorbate system was decomposed into contributions from occupied and unoccupied orbitals of the finite copper cluster and of the 2H-TPP. The resulting interaction diagram showed that the binding in this system can largely be explained by the Dewar, Chatt and Duncanson model which has, for example, been applied to benzene on $\mathrm{Cu}(110) .{ }^{46}$ The charge redistribution upon adsorption is in part due to electron donation from the HOMO of $2 \mathrm{H}$-TPP to the metal surface, and back donation from the surface to the LUMO. Because of the decreased metal-adsorbate distance (increased overlap), the molecule/surface states are more disperse for 

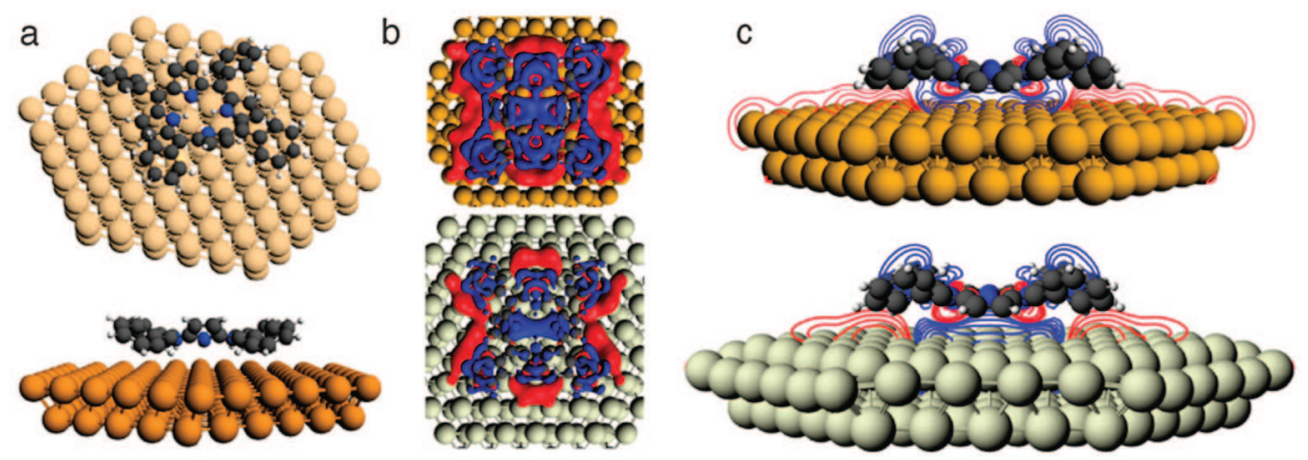

Figure 4. (a) Top and side view of the optimized geometry of $2 \mathrm{H}-\mathrm{TPP}$ on top of a $\mathrm{Cu}(111)$ slab. (b) Top views and (c) side views of the calculated differences between the charge density of the metal-organic systems and that of the isolated, distorted fragments. They illustrate how the charge density changes upon adsorption of the $2 \mathrm{H}-\mathrm{TPP}$ molecule to the metal surfaces $\mathrm{Cu}(111)$ (top) and $\mathrm{Ag}(111)$ (bottom), with blue being a decrease and red an increase. The same isovalue of \pm 0.0003 au was employed to obtain all contours. The lone N-pair is aligned horizontally in (b).

the $\mathrm{Cu}(111)$ surface. Our findings are in agreement with the increase in nobleness of a metal descending down Group 11 from $\mathrm{Cu}$ to $\mathrm{Ag}$ to $\mathrm{Au} .^{2}$ The build up of charge surrounding the copper-molecule interface (the red isovalue in Figure $4 \mathrm{c})$, along with the charge on the molecules themselves, both which are much larger for the 2H-TPP-Cu system than for 2H-TPP-Ag, prevents the adsorbate molecules from interacting with one another due to electrostatic repulsion, thereby impeding self-assembly on the $\mathrm{Cu}(111)$ surface.

The charge density difference plots in Figure 4 reflect strong variations in the charge density at the interface upon adsorption: there is charge depletion (blue) directly under the center of the molecules and an increase in the charge density (red) along the edges of the molecule and under the phenyl ligands. The underlying mechanism here is Pauli repulsion, which follows from the quantum mechanical requirement that overlapping electronic states must be orthogonal to each other. This drives up the energy and as a result pushes charge away at the surface of the $\mathrm{Cu}$ in an area directly under the center of the molecule. This effect has been described as the "pillow effect."3,23-25 The redistribution and exchange of charge also changes drastically the surface dipole of the $\mathrm{Cu}$ and is at the origin of the observed spatial variation of the work function. By comparison, the smaller charge transfer from $\mathrm{Ag}$ to the adsorbate is in line with a weaker binding energy, a longer metal-adsorbate distance and a smaller pillow effect occurring on the metal's surface.

Besides the electrostatic repulsion between the molecules there are also attractive interactions, mainly van-der-Waals and dispersive interactions. Additional bonding contributions come from $\mathrm{CH}-\Pi$ and $\Pi-\Pi$ interactions between the phenyl ligands. For a freestanding $2 \mathrm{H}-\mathrm{TPP}$ dimer, the total binding energy was estimated to be $0.3 \mathrm{eV}$. The net effect is thus dependent on the competition between Coulomb repulsion and the mainly van der Waals attraction. The net force is attractive for $2 \mathrm{H}$-TPP on $\operatorname{Ag}(111)$ and $\mathrm{Au}(111)^{10,18,26}$ and repulsive on $\mathrm{Cu}(111)$, owing to the discussed differences in charge transferred and Coulomb repulsion. A similar dominance of the electrostatic repulsion has been reported earlier for other organic-metallic interface systems. ${ }^{10,27-30,38}$ In addition here, the distorted phenyl arms of the molecules impede the formation of $\Pi-\Pi$ bonds, thereby further decreasing the propensity of binding between two $2 \mathrm{H}-\mathrm{TPP}$ molecules.
Our experimental and computational results are suggesting strong interaction between the TPP and the $\mathrm{Cu}(111)$ surface. Very recent publications by Doyle et al. ${ }^{41}$ and Buchner et al..$^{39}$ have in fact proposed that the two iminic nitrogens in the TPP form an intermediate complex with copper atoms in the surface layer, which aligns the molecules along the $\langle 110\rangle$ directions of the substrate surface. This provides a good explanation for the alignment of the molecules in Figure $1 \mathrm{~b}$ and c. Our presented DFT calculations reveal now additional details about the bond length, the role of the iminic nitrogens in the bonding of the molecule to the substrate, their charge and geometry.

The observed differences in the interactions of $2 \mathrm{H}$-TPP on $\mathrm{Ag}$ and $\mathrm{Cu}$ surfaces were exploited to actually control the inter-molecular forces, between the repulsive and attractive limits by engineering the metal-organic interface. The trick is to deposit the molecules on the $\mathrm{Cu}(111)$, which was pre-covered by an Ag buffer layer of variable thickness. We refer to the literature for structural details of heteroepitaxial Ag on $\mathrm{Cu}(111) \cdot{ }^{42-44}$ The STM images of $2 \mathrm{H}$-TPP adsorbed on 1 to 3 monolayers of $\mathrm{Ag}$ on $\mathrm{Cu}(111)$ are shown in Figure 5. Clearly, the molecules remain, more or less, statistically distributed on $1 \mathrm{ML} \mathrm{Ag/Cu}$, while islands of extended networks, identical in architecture to that found on $\mathrm{Ag}(111)$ in Figure 1a, are observed for the $2 \mathrm{H}$-TPP adsorbed on $3 \mathrm{ML} \mathrm{Ag} / \mathrm{Cu}$. At the intermediate Ag buffer layer thickness of $2 \mathrm{ML}$, clusters of $2 \mathrm{H}$ TPP adsorbed molecules are commonly observed but with noticeable degree of disorder within such clusters. On Ag layers on $\mathrm{Cu}$, the 2H-TPP molecules appear in 2 distinctively different symmetries: the symmetry labeled (i) which is usually observed on $\mathrm{Cu}(111)$, and the symmetry labeled (ii) which is typical for TPP on $\mathrm{Ag}(111)$. With increasing Ag layer thickness, the occurrence of $2 \mathrm{H}$-TPP molecules in configurations of type (i) decreases while at the same time the occurrence of the 2H-TPP adsorbed molecules in the arrangement of type (ii) increases. It appears as if clusters of molecules, ordered or disordered, are mostly formed by $2 \mathrm{H}$-TPP adsorbed molecules of type (ii). We ascribe this difference in the conformation to differences in the molecule-substrate complex formation proposed in ref. 41. This implies that there is some degree of intermixing with the $\mathrm{Cu}$ substrate in the first Ag layer.

Tunneling spectroscopy was again employed to elucidate the local electronic structure of the interface. A work function 

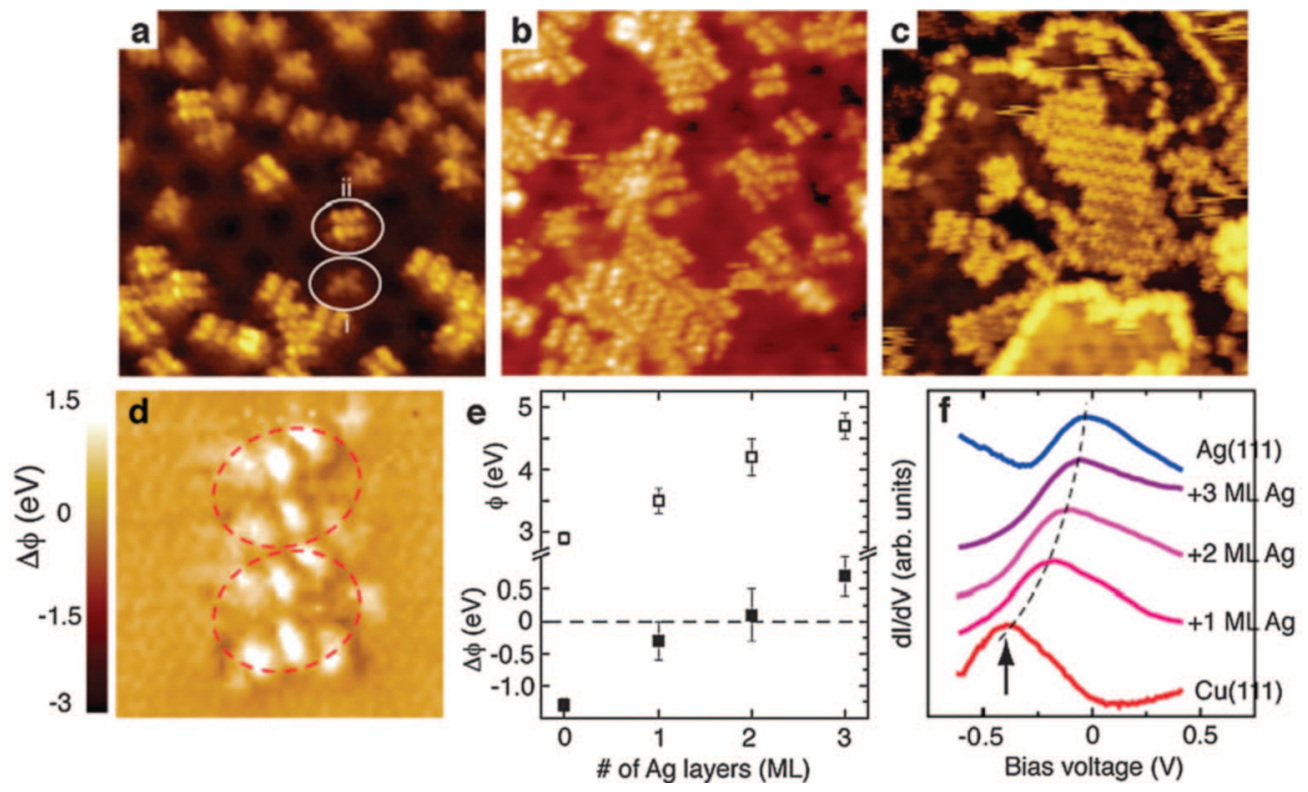

Figure 5. STM images of $2 \mathrm{H}-\mathrm{TPP}$ on Ag buffer layers of thickness $t_{\mathrm{Ag}}$ on $\mathrm{Cu}(111)$ where $t_{\mathrm{Ag}}=1 \mathrm{ML}(\mathrm{a}), t_{\mathrm{Ag}}=2 \mathrm{ML}(\mathrm{b}), t_{\mathrm{Ag}}=3 \mathrm{ML}(\mathrm{c})$. Two different shapes of the molecules are observed, labeled (i) and (ii), see text for explanation. Image size $15 \mathrm{~nm} \times 15 \mathrm{~nm}$. (d) Work function map of a TPP dimer on $2 \mathrm{ML} \mathrm{Ag/Cu(111).} \mathrm{The} \mathrm{position} \mathrm{of} \mathrm{each} \mathrm{TPP} \mathrm{is} \mathrm{circled.} \mathrm{The} \mathrm{color} \mathrm{bar} \mathrm{is} \mathrm{the} \mathrm{same} \mathrm{as} \mathrm{in} \mathrm{Figure} \mathrm{3.} \mathrm{(e)} \mathrm{Work} \mathrm{function} \mathrm{measured} \mathrm{lo-}$ cally in the center of a TPP molecule, as a function of Ag thickness (open square), and the change in the work function compared to the substrate, $\Delta \varphi$, obtained from integrating over one TPP molecule (solid square). (f) STS point spectra on $\mathrm{Cu}, \mathrm{Ag}$ films on $\mathrm{Cu}$, and $\mathrm{Ag}$ substrates showing the Shockley surface state.

map of a TPP dimer on $2 \mathrm{ML} \mathrm{Ag} / \mathrm{Cu}(111)$ is shown in Figure 5d, using the same color scale as in Figure 3b. Evidently, there is no significant decrease of the work function as compared to the bare $\mathrm{Ag} / \mathrm{Cu}$ system in the center of the molecule, in sharp contrast to our observation for TPP on $\mathrm{Cu}(111)$. This is further reflected in the trend of the work function as a function of Ag spacer thickness, shown in Figure 5e. Both, the work function measured locally in the center of a TPP molecule as well as the work function averaged over one molecule, are plotted for comparison. Strikingly, there is a strong dependence of the work function near the center of the molecules on the thickness of the Ag layer, revealing that the Ag thickness governs the charge distribution at the metal-organic interface. The work function integrated over a molecule is changing its sign from an overall decrease compared to the substrate to an increase at $t_{\mathrm{Ag}}=2 \mathrm{ML}$, which is the coverage where also TPP cluster formation sets in. The local spectrum of electronic states taken on top of the molecules is similar for all samples in Figure 5a-c (not shown). However, the Shockley surface state of the substrate on the other hand shifts upward in energy with increasing thickness of the Ag buffer layer, from $-400 \mathrm{meV}$ for clean $\mathrm{Cu}(111)$ to $-50 \mathrm{meV}$ for $\mathrm{Ag}$ (111) (Figure $5 f$ ). The energy of this Shockley state is thus a precise indicator for the Ag layer thickness. Key is that the energy of the Shockley state can be adjusted by the Ag buffer layer thickness between the two extremes of pure $\mathrm{Ag}(111)$ and $\mathrm{Cu}(111)$ surfaces.

\section{Conclusions}

It has been already established that the electronic level alignment at the metal-organic interface and frontier orbital symmetry determines the hybridization of levels and the amount of charge transferred across the interfaces. ${ }^{1,31}$ Based on the results shown here, we find it reasonable to assume that the Shockley state plays a crucial role for the interaction strength. Depending on the exact energetic position of this state, more or less overlap with the corresponding molecule levels is possible, thereby facilitating $(\mathrm{Cu})$ or impeding $(\mathrm{Ag})$ charge transfer across the interface. By controlling the exact energetic position of the surface state by the choice of thickness of $\mathrm{Ag}$ buffer layers on $\mathrm{Cu}(111)$, the degree of electronic level hybridization can thus be finely tuned, to adjust the amount of charge transferred and the strength of the Coulomb repulsion. Since the van der Waals interaction remains unaffected by this, the net effect can thus be chosen to be repulsive or attractive. The ability to control inter-molecular forces for a particular type of molecule between both extremes in this manner opens new possibilities to steer molecular self-assembly, especially if patterned buffer layers are used. It is thus an important new milestone in establishing rational design principles for organics in contact with surfaces. Specifically, we demonstrated the potential of using substrates to build organic structures and frameworks of potentially greater complexity than currently possible, exhibiting pre-defined and desired functionality.

\section{Experimental}

The experiments were carried out using an Omicron low temperature scanning tunneling microscope in an ultrahigh vacuum system with a base pressure of $8 \times 10^{-11}$ mbar. Single crystalline substrates have been cleaned in UHV by $\mathrm{Ar}^{+}$ ion sputtering and annealing. TPP molecules have been deposited by thermal evaporation from a home-built Knudsen cell, with the substrate held at room temperature. The combined photoemission and inverse photoemission spectroscopy measurements have been performed in a second UHV system $^{32}$ but using the same substrates and Knudsen cells. 
The DFT-D calculations were carried out using the ADF software package. ${ }^{33,34}$ The revPBE gradient density functional ${ }^{35}$ was employed, and Grimme's latest dispersion corrected functional ${ }^{36}$ was used to account for the dispersion forces. Tests were performed to determine the effect of the basis set on the binding energy of benzene to an $\operatorname{Ag}(111)$ slab. For the results given in the main text, the basis functions on all of the atoms consisted of a valence triple- $\zeta$ Slatertype basis set with polarization functions (TZP) from the ADF basis-set library. The core shells up to $1 \mathrm{~s}, 1 \mathrm{~s}, 3 \mathrm{p}$ and $4 p$ of carbon, nitrogen, copper and silver, respectively, were kept frozen. A Hirschfeld charge analysis was used to determine the magnitude of the charge transferred between the adsorbate and the metal surface. More computational details and complementary results are provided in the Supplementary Information.

Acknowledgments - This work was supported by the National Science Foundation, in parts by the NSF grants DMR0747704 (CAREER), DMR-0213808 (MRSEC) and CHE0909580 grant EPS-1004094. Support from the Center of Computational Research at SUNY Buffalo is acknowledged.

\section{References}

1 H. Ishii, K. Sugiyama, E. Ito and K. Seki, Adv. Mater., 1999, 11(8), 605-625

2 B. Hammer and J. K. Nørskov, Nature, 1995, 376, 238

3 P. S. Bagus, K. Hermann and Ch. Wöll, J. Chem. Phys., 2005, 123, 184109

4 R. Temirov, S. Soubatch, A. Luican and F. Tautz, Nature, 2006, 444, 350-353

5 T. Lukasczyk, K. Flechtner, L. R. Merte, N. Jux, F. Maier, J. M. Gottfried and H.-P. Steinrück, J. Phys. Chem. C, 2007, 111, 3090-3098

6 L. Romaner, G. Heimel, J.-L. Brédas, A. Gerlach and F. Schreiber, Phys. Rev. Lett., 2007, 99, 256801

7 S. Bedwani, D. Wegner, M. F. Crommie and A. Rochefort, Phys. Rev. Lett., 2008, 101, 216105

8 A. Scheybal, K. Müller, R. Bertschinger, M. Wahl, A. Bendounan, P. Aebi and T. A. Jung, Phys. Rev. B: Condens. Matter, 2009, 79, 115406

9 W. Shockley, Phys. Rev., 1939, 56, 317

10 G. Rojas, X. Chen, C. Bravo, J. Kim, J.-S. Kim, J. Xiao, P. A. Dowben, Y. Gao, X. C. Zeng, W. Choe and A. Enders, J. Phys. Chem. C, 2010, 114, 9408-9415

11 J. Brede, M. Linares, S. Kuck, J. Schwöbel, A. Scarfato, S.-H. Chang, G. Hoffmann, R. Wiesendanger, R. Lensen, P. H. J. Kouwer, J. Hoogboom, A. E. Rowan, M. Bröring, M. Funk, S. Stafström, F. Zerbetto and R. Lazzaroni, Nanotechnology, 2009, 20, 275602

12 F. Buchner, K. Flechtner, Y. Bai, E. Zillner, I. Kellner, H.-P. Steinrück, H. Marbach and J. M. Gottfried, J. Phys. Chem. C, 2008, 112, 15458

13 R. Thorpe, R. A. Bartynski, J. Rochford, S. Rangan, S. Katalinic and E. Galoppini, J. Phys. Chem. C, 2010, 114, 1139-1147

14 M.-S. Liao and S. Scheiner, J. Chem. Phys., 2002, 117(1), 205

15 S. D. Kevan, Phys. Rev. Lett., 1983, 50, 526

16 O. Jeandupeux, L. Bürgi, A. Hirstein, H. Brune and K. Kern, Phys. Rev. B: Condens. Matter, 1999, 59(24), 15926-15934

17 W. Auwärter, K. Sufert, F. Klappenberger, J. Reichert, A. WeberBargioni, A. Verdini, D. Cvetko, M. Dell' Angela, L. Floreano, A. Cossaro, G. Bavdek, A. Morgante, A. P. Seitsonen and J. V. Barth, Phys. Rev. B: Condens. Matter, 2010, 81(24), 245403

18 K. Comanici, F. Buchner, K. Flechtner, T. Lukasczyk, M. Gottfried, H.-P. Steinrück and H. Marbach, Langmuir, 2008, 24(5), 1897-1901
19 L. Vitali, G. Levita, R. Ohmann, A. Comisso, A. De Vita and K. Kern, Nat. Mater., 2010, 9, 320-323

20 W. Auwärter, A. Weber-Bargioni, A. Riemann, A. Schiffrin, O. Gröning, R. Fasel and R. J. V. Barth, J. Chem. Phys., 2006, 124(19), 194708

21 W. Auwärter, A. Weber-Bargioni, S. Brink, A. Riemann, A. Schiffrin, M. Ruben and J. V. Barth, ChemPhysChem, 2007, 8, 250

22 F. Buchner, K.-G. Warnick, T. Wölfle, A. Görling, H.-P. Steinrück, W. Hieringer and H. Marbach, J. Phys. Chem. C, 2009, 113, 16450-16457

23 P. S. Bagus, V. Staemmler and Ch. Wöll, Phys. Rev. Lett., 2002, 89, 096104

24 H. Vázquez, Y. J. Dappe, J. Ortega and F. Flores, Appl. Surf. Sci., 2007, 254, 378

25 P. C. Rusu, G. Giovannetti, C. h. Weijtens, R. Coehoorn and G. Brocks, Phys. Rev. B: Condens. Matter, 2010, 81, 125403

26 Z. C. Dong, X. L. Zhang, H. Y. Gao, Y. Luo, C. Zhang, L. G. Chen, R. Zhang, X. Tao, Y. Zhang, J. L. Yang and J. G. Hou, Nat. Photonics, 2010, 4, 50-54

27 D. Wegner, R. Yamachika, Y. Wang, V. W. Brar, B. M. Bartlett, J. R. Long and M. F. Crommie, Nano Lett., 2008, 8(1), 131-135

28 I. Fernandez-Torrende, S. Monturet, K. Franke, J. Fraxedas, N. Lorente and J. Pascual, Phys. Rev. Lett., 2007, 99, 176103

29 Z. G. Soos and B. J. Topham, Org. Electron., 2011, 12, 39-44

30 C. Wagner, D. Kasemann, C. Golnik, R. Forker, M. Esslinger, K. Müllen and T. Fritz, Phys. Rev. B: Condens. Matter, 2010, 81, 035423

31 H. Vázquez, R. Oszwaldowski, P. Pou, J. Ortega, R. Pérez, F. Flores and A. Kahn, Europhys. Lett., 2004, 65, 802

32 J. Zhang, D. N. McIlroy, P. A. Dowben, H. Zeng, G. Vidali, D. Heskett and M. Onellion, J. Phys.: Condens. Matter, 1995, 7, 7185

33 G. te Velde, F. M. Bickelhaupt, E. J. Baerends, C. Fonseca Guerra, S. J. A. van Gisbergen, J. G. Snijders and T. Ziegler, J. Comput. Chem., 2001, 22, 931-967

34 E. J. Baerends, J. Autschbach, A. Bérces, F. M. Bickelhaupt, C. Bo, P. M. Boerrigter, L. Cavallo, D. P. Chong, L. Deng and R. M. Dickson, et al., ADF2006.01, SCM, Theoretical Chemistry, Vrije Universiteit, Amsterdam, The Netherlands; http:/ / www.scm.com

35 J. P. Perdew, K. Burke and Y. Wang, Phys. Rev. B: Condens. Matter, 1996, 54, 16533-16539

36 S. Grimme, J. Antony, S. Ehrlich and H. Krieg, J. Chem. Phys., 2010, 132, 154104

37 S. Kuck, S.-H. Chang, J.-P. Klöckner, M. H. Prosenc, G. Hoffmann and R. Wiesendanger, ChemPhysChem, 2009, 10, 2008-2011

38 Ch. Stadler, S. Hansen, I. Kröger, Ch. Kumpf and E. Umbach, Nat. Phys., 2009, 5, 153-158

39 (a) F. Buchner, J. Xiao, E. Zillner, M. Chen, M. Röckert, S. Ditze, M. Stark, H.-P. Steinrück, J. M. Gottfried and H. Marbach, J. Phys. Chem. C, 2011, 115, 24172-24177 ; (b) F. Buchner, E. Zillner, M. Röckert, S. Glässel, H.-P. Steinrück and H. Marbach, Chem.-Eur. J., 2011, 17, 10226-10229

40 T. Yokoyama, T. Takahashi and K. Shinozaki, Phys. Rev. Lett., 2007, 98, 206102

41 C. M. Doyle, S. A. Krasnikov, N. N. Sergeeva, A. B. Preobrajenski, N. A. Vinogradov, Y. N. Sergeeva, M. O. Senge and A. A. Cafolla, Chem. Commun., 2011, 47, 12134-12136

42 E. Bauer, Appl. Surf. Sci., 1982, 11-12, 479

43 I. Meunier, G. Treglia, J.-M. Gay, B. Aufray and B. Legrand, Phys. Rev. B: Condens. Matter, 1999, 59(16), 10910

44 K. Umezawa, S. Nakanishi, M. Yoshimura, K. Ojima, K. Ueda and W. M. Gibson, Phys. Rev. B: Condens. Matter, 2000, 63, 035402

45 G. Di Santo, S. Blankenburg, C. Castellarin-Cudia, M. Fanetti, P. Borghetti, L. Sangaletti, L. Floreano, A. Verdini, E. Magnano, F. Bondino, C. A. Pignedoli, M. Nguyen, R. Gaspari, D. Passerone and A. Goldoni, Chem.-Eur. J., 2011, 17, 14354

46 L. Triguero, A. Föhlisch, P. Vaterlaein, J. Hasselström, M. Weinelt, L. G. M. Petterson, Y. Luo, H. Agren and A. Nilsson, J. Am. Chem. Soc., 2000, 122, 12310 


\section{Section 1: Computational Details}

The DFT-D calculations were carried out using the ADF software package ${ }^{1,2}$. The revPBE gradient density functional ${ }^{3-6}$ was employed, and Grimme's latest dispersion corrected functional ${ }^{7}$ was used to account for the dispersion forces. Tests were performed to determine the effect of the basis set on the binding energy of benzene to an $\mathrm{Ag}(111)$ slab, see Section 3 below. For the results given in the main text, the basis functions on all of the atoms consisted of a valence triple- $\zeta$ Slater-type basis set with polarization functions (TZP) from the ADF basis-set library. The core shells up to $1 \mathrm{~s}, 1 \mathrm{~s}, 3 \mathrm{p}$ and $4 \mathrm{p}$ of carbon, nitrogen, copper and silver, respectively, were kept frozen. In situations where SCF convergence issues arose, the steepest decent method was employed. Both a Mulliken and a Hirshfeld charge analysis were used to determine the magnitude of the charge transferred between the adsorbate and the metal surface.

The $\mathrm{Cu}(111)$ and $\mathrm{Ag}(111)$ surfaces were simulated by using a finite slab, or cluster, comprised of 166 metal atoms and the experimental lattice parameter of $3.614 \AA^{8}$ and $4.086 \AA^{8}$, respectfully. The clusters were composed of two layers with the top layer containing 91 atoms and the bottom layer containing 75 atoms. During the structural relaxation, the top layer of the slabs was allowed to relax. Next, a geometry optimization was performed where the $2 \mathrm{H}-\mathrm{TPP}$ was placed on-top of the optimized metal surface, and the coordinates of the cluster atoms were kept fixed. This procedure was found to give binding energies (BEs) in reasonable agreement with experimental data obtained for benzene adsorbed on $\operatorname{Ag}(111) / \mathrm{Cu}(111)$ (see Section 3 of the Supplementary Information, SI). For select systems, the basis set superposition error (BSSE) was calculated using the Counterpoise method.

To clarify the nature of the bonding, a fragment orbital analysis was employed using the ADF program $^{1}$. The fragments used were those of the metal cluster and distorted adsorbate (as found in the optimized structures S3, S5, S6 and S7). The composition of the molecular orbitals of the metaladsorbate system was decomposed into terms of occupied and unoccupied orbitals of the finite metal cluster and of the adsorbate. From this analysis, charge density difference (CDD) contours and isosurfaces were plotted using the ADFview program. The CDD given below are the calculated differences between the charge density of the metal-organic systems and that of the isolated fragments. They illustrate how the charge density changes upon adsorption of the molecule to the metal surface. 


\section{Section 2: 2H-TPP Dimer Binding Energies}

The coordinates for the adjacent 2H-TPP dimer (S1) and the sandwich 2H-TPP dimer (S2) can be found in Section 5 of the SI. The basis functions on all of the atoms consisted of a valence triple- $\zeta$ Slater-type basis set with polarization functions (TZP) from the ADF basis-set library. The core shells up to $1 \mathrm{~s}$ of carbon and nitrogen were kept frozen. The binding energy (BE) of S1 was calculated as being $0.03 \mathrm{eV}$. The binding energy of $\mathbf{S 2}$ was found to be $1.12 \mathrm{eV}$.

Figure 1: Illustrations of the geometries of the (a) adjacent (S1), and (b) sandwich (S2) 2H-TPP dimer.

a)

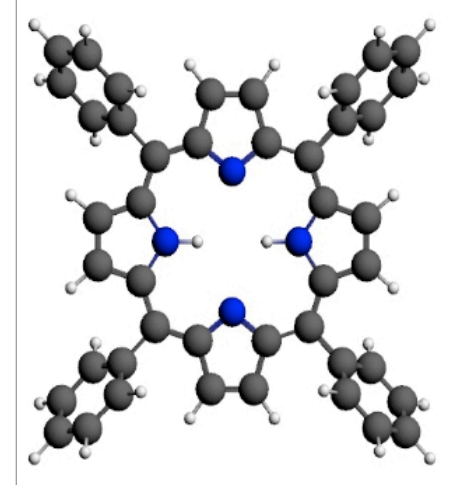

b)

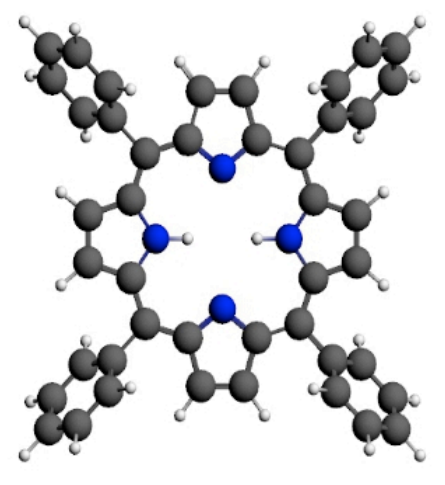

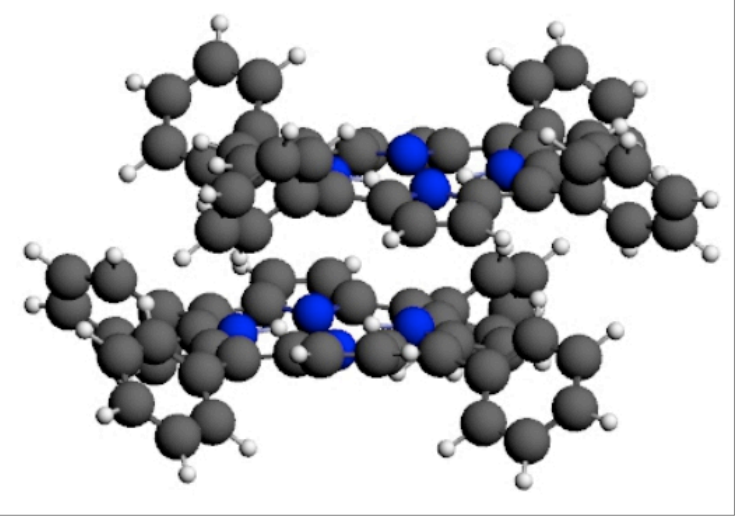

The most stable benzene dimer $(\mathbf{S 8})^{9}$ has a geometry which is very similar to that of S2. Using the computational settings described herein, the binding energy for the benzene dimer was found to be 0.05 $\mathrm{eV}$, which is somewhat smaller than that computed by high-level $\operatorname{CCSD}(\mathrm{T})$ calculations ${ }^{9}$ for the parallel-displaced benzene dimer ( 0.09 to $0.12 \mathrm{eV})$.

\section{Section 3: Benzene on Various Copper/Silver Surfaces}

The geometries of benzene adsorbed to metal clusters (models for various metal surfaces) were optimized, and the BEs computed. In the following geometry optimizations the bottom layer of metal atoms was kept fixed, but the top layer of atoms was allowed to relax. For benzene adsorbed on the $\operatorname{Ag}(111)$ surface computations were performed using different basis sets, and varying the number of atoms in the cluster. The BE, given below in Table 1, were calculated by:

$\mathrm{BE}=E_{(\text {Organic Molecule })}+E_{(\text {Metal Slab })}-E_{(\text {Organic-Metal Complex })}$

Table 1: The binding energy $(\mathrm{BE})$ of benzene to $\mathrm{Ag}(111)$ using various basis sets and slab sizes ${ }^{\mathrm{a}}$

\begin{tabular}{|l|l|l|l|l|}
\hline System & \# of Surface Atoms & Adsorbate Basis & Surface Basis & BE (eV) \\
\hline Benzene-Ag(111) & 64 & DZP & DZ & 1.16 \\
\hline Benzene-Ag(111) & 64 & TZP & DZ & 0.98 \\
\hline Benzene-Ag(111) & 64 & DZP & TZP & 1.10 \\
\hline Benzene-Ag(111) & 64 & TZP & TZP & 0.87 \\
\hline Benzene-Ag(111) & 166 & TZP & TZP & 0.77 \\
\cline { 2 - 4 } & \multicolumn{2}{|l|}{ Experimental BE } & 0.56 \\
\cline { 2 - 4 }
\end{tabular}

${ }^{a}$ DZ denotes a double- $\zeta$ basis; DZP is a double- $\zeta$ basis with polarization functions; TZP is a triple- $\zeta$ basis set with polarization functions. 
A TZP basis set on the adsorbate atoms and the surface atoms was found to give a BE which was closest to the experimental values. Moreover, as the number of atoms used to simulate the metallic slab increased, the computed BE was found to approach the experimental BE.

The computed BE between benzene and various copper/silver surfaces are given below in Table 2 . The results shown in Table 1 and 2 illustrate that computational method employed overestimates the BE for these types of systems, in-line with the original benchmark calculations ${ }^{7}$. The BSSE lowers the computed BEs slightly. For example, the BSSE-corrected BE of benzene on $\mathrm{Cu}(111)$ and $\mathrm{Ag}(111)$ with 64 atoms in the cluster was found to be 1.11 and $0.79 \mathrm{eV}$, respectfully.

The optimized coordinates of the $\operatorname{Ag}(111)$-benzene system with 64 silver atoms (S3), the $\operatorname{Ag}(111)$ benzene system with 166 silver atoms (S4), and the $\mathrm{Cu}(111)$-benzene system (S5) can be found in Section 5 of the SI.

Table 2: The binding energy (BE) of benzene to various copper and silver surfaces ${ }^{\mathrm{a}}$

\begin{tabular}{|l|l|l|}
\hline System & $\begin{array}{l}\text { Calculated } \\
\text { BE (eV) }\end{array}$ & $\begin{array}{l}\text { Experimental } \\
\text { BE (eV) }\end{array}$ \\
\hline $\mathrm{Cu}(100)-$ Benzene $^{\mathrm{b}}$ & 1.03 & - \\
\hline $\mathrm{Cu}(110)$-Benzene $^{\mathrm{c}}$ & 1.27 & $0.73^{10}$ \\
\hline $\mathrm{Cu}(111)-$ Benzene $^{\mathrm{d}}$ & 1.28 & $0.59^{11}$ \\
\hline $\mathrm{Ag}(100)-$ Benzene $^{\mathrm{b}}$ & 0.67 & - \\
\hline $\mathrm{Ag}(111)-$ Benzene $^{\mathrm{d}}$ & 0.87 & $0.56^{7}$ \\
\hline
\end{tabular}

${ }^{\mathrm{a}}$ TZP basis sets were use for all of the atoms; ${ }^{b}$ Slab contained 74 atoms; ${ }^{c}$ Slab contained 134 atoms;

${ }^{\mathrm{d}}$ Slab contained 64 atoms.

The differences between the charge densities of the isolated fragments and that of the metal-adsorbate system were calculated. In the charge density difference (CDD) isosurfaces provided herein, red denotes a gain of electrons, and blue a loss of electrons upon adsorption. Charge density difference isosurfaces were calculated for the $\mathbf{S 3}$ and $\mathbf{S 5}$ structures (Figures $2 \mathrm{a}$ and $2 \mathrm{~b}$ ).

Figure $2 \mathrm{~b}$ is illustrative of the "Pillow Effect", which is caused by Pauli repulsion between the metal and adsorbate electron densities ${ }^{12}$. The charge redistribution is also a result of electron donation from the HOMO of benzene to the metal surface, and back-donation from the surface to the benzene LUMO (the Dewar, Chatt, and Duncason model which has, for example, been applied to benzene on $\left.\mathrm{Cu}(110)^{13}\right)$. A Mulliken analysis illustrates that for both $\mathbf{S 3}$ and $\mathbf{S 5}$ there is a charge transfer of 0.19e to the metal cluster, whereas the Hirschfeld scheme yields $0.16 \mathrm{e}$, and $0.27 \mathrm{e}$ for $\mathrm{Ag}(111)$ and $\mathrm{Cu}(111)$, respectively. Mulliken charges are strongly basis set dependent, and the Hirschfeld method may provide results which are more in-line with chemical intuition since the promolecular fragments are the same as those employed in our CDD calculations. The benzene to $\mathrm{Ag} / \mathrm{Cu}$ surface distance was found to be 3.84/2.76 angstroms. The closer the adsorbate is to the metal, the stronger the binding energy and the more pronounced is the CDD. 
Figure 2: Charge density difference (CDD) isosurfaces of benzene on an: (a) $\operatorname{Ag}(111)$ (S3), and (b) $\mathrm{Cu}(111)$ slab (S5). The slabs contained 64 atoms and the isovalues are $+/-0.0003 \mathrm{au}$.

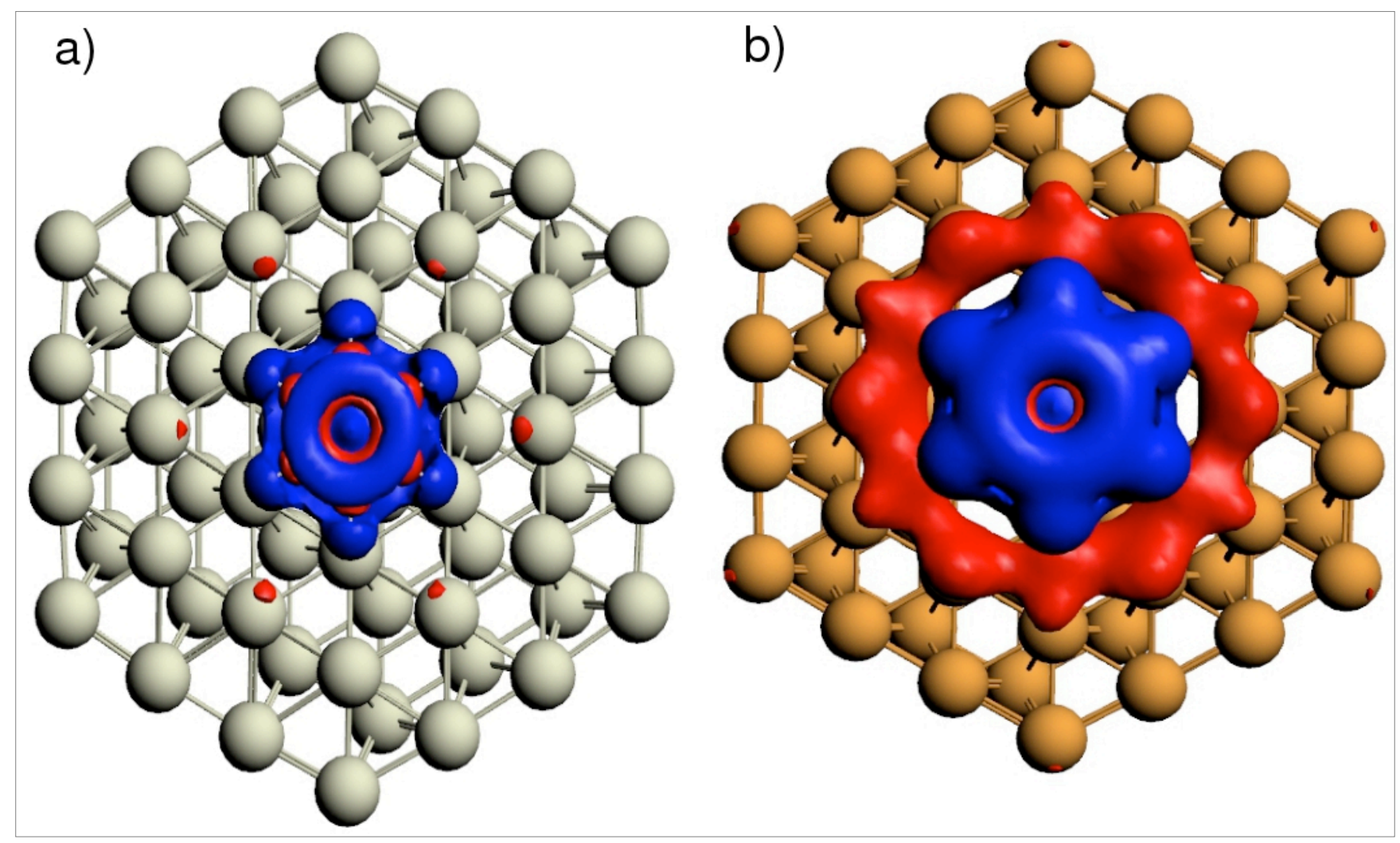

\section{Section 4: Cu(111)/2H-TPP and Ag(111)/2H-TPP}

Geometry optimizations were performed as previously described in Section 1, with the $\mathrm{Cu}(111)$ and $\operatorname{Ag}(111)$ clusters both containing 166 atoms. The coordinates of the following systems can be found in Section 5, and the BE are given in Table 3.

Table 3: Binding energies (BE) and structural parameters of $2 \mathrm{H}-\mathrm{TPP}$ with $\mathrm{Cu}(111)$ and $\mathrm{Ag}(111)^{\mathrm{a}}$

\begin{tabular}{|c|c|c|c|c|c|c|}
\hline System & BE $(e V)^{b}$ & $\begin{array}{l}\text { Surface } \\
\text { Charge } \\
\text { (Mulliken) }\end{array}$ & $\begin{array}{l}\text { Surface } \\
\text { Charge } \\
\text { (Hirschfeld) }\end{array}$ & Dihedral & $\begin{array}{l}\text { N1-surface } \\
\text { Distance }(\AA)\end{array}$ & $\begin{array}{l}\text { N2-Surface } \\
\text { Distance }(\AA)\end{array}$ \\
\hline $\mathrm{Cu}(111$ & $6.19 / 5.31$ & $-1.69 \mathrm{e}$ & $-0.89 \mathrm{e}$ & 38.3 & 3.05 & 3.05 \\
\hline $\operatorname{Ag}(111$ & $3.44 / 3.07$ & $-1.45 \mathrm{e}$ & $-0.46 \mathrm{e}$ & 42.1 & 3.30 & 3.29 \\
\hline
\end{tabular}

${ }^{a}$ The atoms $\mathrm{C} 1, \mathrm{C} 2, \mathrm{C} 3$ and $\mathrm{C} 4$ which define the dihedral angle given are illustrated in Figure 3 . The $\mathrm{N} 1$ and $\mathrm{N} 2$ atoms are defined in Figure 3.

${ }^{\mathrm{b}}$ The uncorrected/BSSE corrected binding energies. 
Figure 3: The carbon atoms which define the dihedral angle, and the nitrogen atoms given in Table 3.

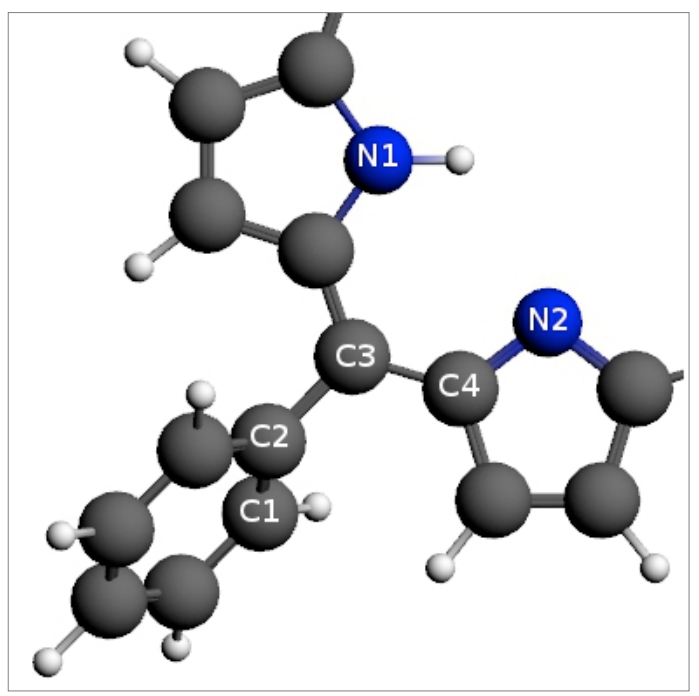

Figure 4: Charge density difference (CDD) isosurfaces of 2H-TPP on an: (a) Cu(111) (S6), and (b) $\mathrm{Ag}(111)$ slab (S7). The slabs contained 166 atoms and the isovalues are $+/-0.0003 \mathrm{au}$.

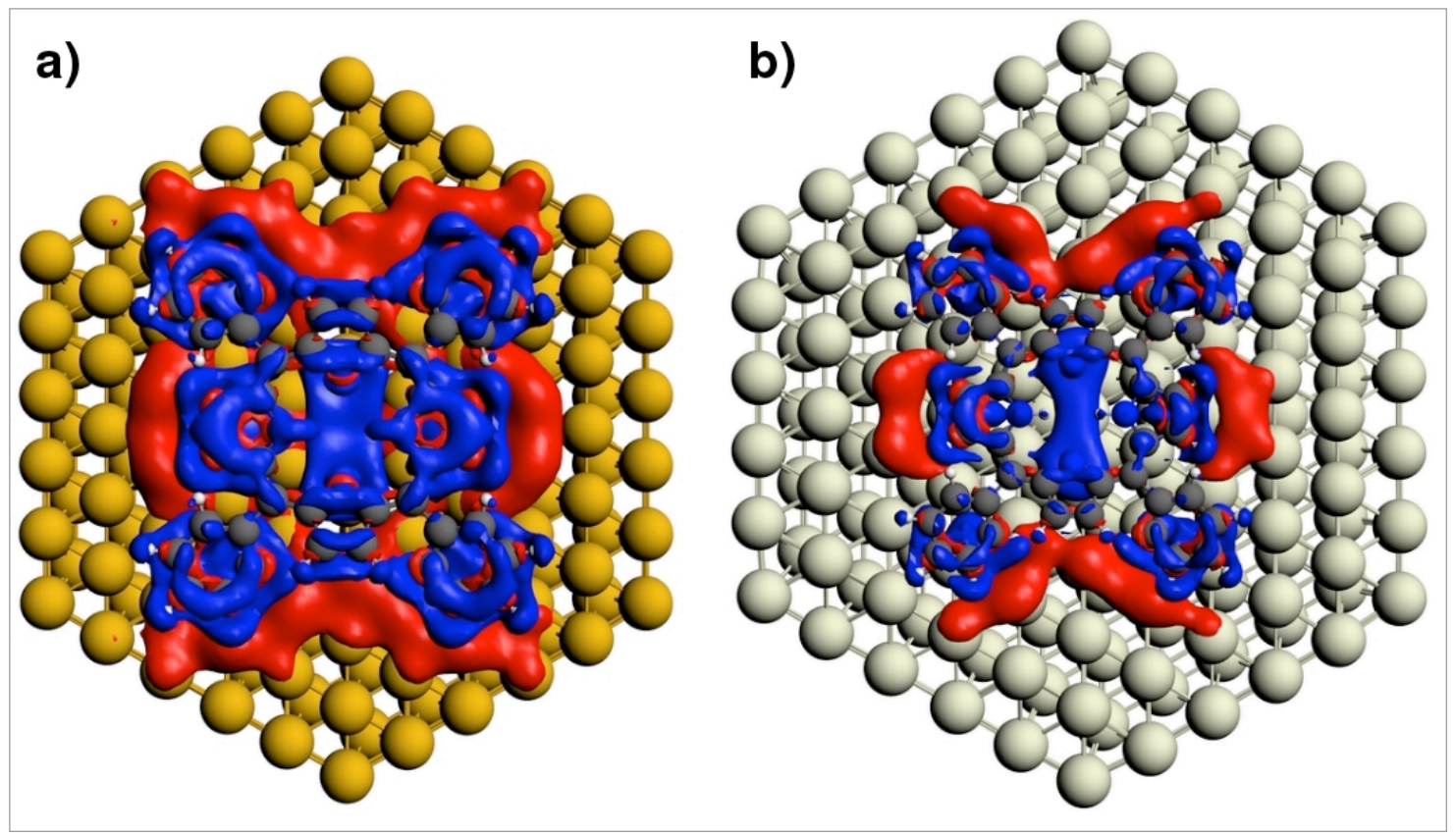

Table 4: Bonding Energy (eV) decomposition analysis for $2 \mathrm{H}-\mathrm{TPP}$ on $\mathrm{Cu}(111)$ and $\mathrm{Ag}(111)$.

\begin{tabular}{|c|c|c|c|c|c|c|}
\hline System & Pauli & Electrostatic & $\begin{array}{c}\text { Steric } \\
\text { Interaction }\end{array}$ & $\begin{array}{c}\text { Orbital } \\
\text { Interaction }\end{array}$ & Dispersion & $\begin{array}{c}\text { Geometric } \\
\text { Distortion }\end{array}$ \\
\hline $\begin{array}{c}\mathrm{Cu}(111 \\
)\end{array}$ & 15.27 & -7.84 & & & & \\
\hline $\mathrm{Ag}(111$ & 8.60 & -4.44 & 4.43 & -5.07 & -9.15 & 0.62 \\
\hline
\end{tabular}


The 2H-TPP molecule distorts as it approaches the $\mathrm{Cu}(111)$ and $\mathrm{Ag}(111)$ surfaces. The phenyl arms rotate so that the dihedral angle, as defined in Figure 3, changes (for free 2H-TPP we compute the dihedral angle to be 62.7 degrees). In both cases the phenyl arms are oriented nearly parallel to the metal surface, with an angle of $26 / 30$ degrees to $\mathrm{Cu}(111) / \mathrm{Ag}(111)$. The ends of the pyrrole rings that contain N1 distort downwards, and the pyrrole rings that contain N2 distort upwards due to the rotation of the phenyl arms of the 2H-TPP.

In accordance with our findings for benzene on $\operatorname{Ag}(111) / \mathrm{Cu}(111)$, the Mulliken charges for the two systems were about the same even though visual inspection of the CDD (Figures 4 and 5) appears to indicate a larger charge redistribution and charge build-up on the $\mathrm{Cu}$ surface. The Hirschfeld charge analysis, on the other hand, shows that there is a larger amount of charge transferred to $\mathrm{Cu}(111)$ than to $\operatorname{Ag}(111)$ suggesting that the repulsion between the positively charged 2H-TPP molecules may hinder their self-assembly. It is likely that the Hirschfeld scheme provides better results for the systems we are considering ${ }^{19}$.

The BSSE uncorrected bonding energy can be decomposed as ${ }^{14}$ :

$\mathrm{BE}=\mathrm{DE}_{\text {bond }}=\mathrm{DE}_{\mathrm{geo}}+\mathrm{DE}_{\text {steric }}+\mathrm{DE}_{\mathrm{oi}}+\mathrm{DE}_{\text {disp }}$

where $\mathrm{DE}_{\text {geo }}$ is the energy necessary to distort the geometry of the $2 \mathrm{H}$-TPP to the one in the total system, $\mathrm{DE}_{\text {steric, }}$, the steric repulsion, is a sum of the Pauli repulsion and the classical electrostatic interaction between the interpenetrating charge densities of the fragments, $\mathrm{DE}_{\mathrm{oi}}$ is the orbital interaction and $\mathrm{DE}_{\text {disp }}$ the dispersion energy. These values are provided in Table 4 .

The distances between $\mathrm{N} 1$ and $\mathrm{N} 2$ and the metal surface is larger for the $\mathrm{Ag}(111)$ than for the $\mathrm{Cu}(111)$ slab, and the resulting charge redistribution upon absorption is smaller as evidenced in Figures 4 and 5. The stronger adsorbate-metal interaction for the $\mathrm{Cu}(111)$ system correlates with the larger magnitude of the steric, orbital and dispersion interaction energies, and the larger energy necessary to distort the $2 \mathrm{H}-$ TPP molecule as it adsorbs to the metal surface.

To clarify the nature of the bonding between $2 \mathrm{H}-\mathrm{TPP}$ and $\mathrm{Cu}(111) / \mathrm{Ag}(111)$, we calculated the composition of the molecular orbitals (MOs) in terms of the occupied and unoccupied MOs of the molecule and the metal cluster. Based upon the results of this analysis approximate interaction diagrams, provided in Fig. 6, can be constructed using the thinking outlined in Refs. [15-18].

These diagrams illustrate that the bonding is similar to benzene, with charge transfer from the 2H-TPP HOMO to the surface, and back donation into the 2H-TPP LUMO. Because of the shorter metaladsorbate distance, the dispersion of the $\mathrm{HOMO} /$ metal and $\mathrm{LUMO} /$ metal bands is larger for $\mathrm{Cu}(111)$. The calculation of the crystal orbital overlap population (COOP) would be necessary for a more indepth analysis of the bonding in the two systems. 
Figure 5: Charge density difference (CDD) contours of 2H-TPP on an: (a) $\mathrm{Cu}(111)$ (S6), and (b) $\operatorname{Ag}(111)$ slab (S7). The slabs contained 166 atoms, and the settings used to obtain the contours in both plots was the same.

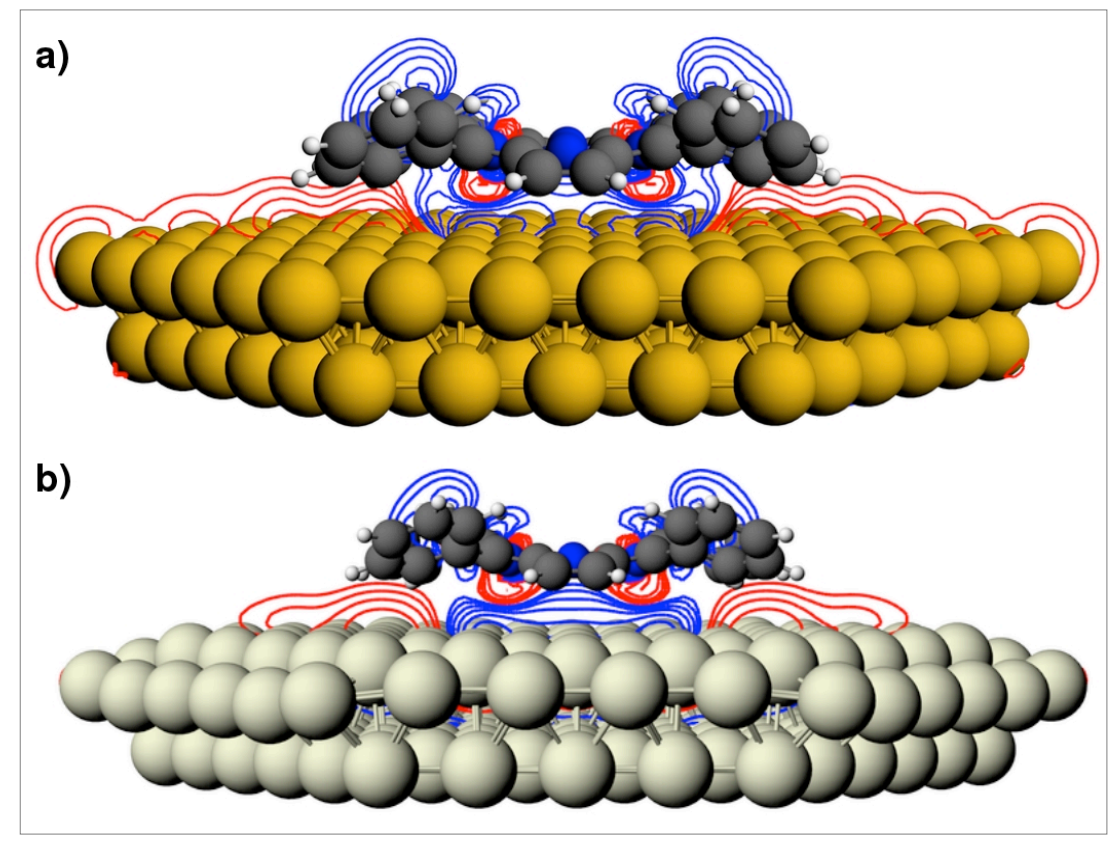

Figure 6: Schematic interaction diagram of $2 \mathrm{H}-\mathrm{TPP}$ with the a) $\mathrm{Ag}(111)$ and b) $\mathrm{Cu}(111)$ surface. The Fermi level has been set to zero. Isosurfaces of the HOMO and LUMO of the 2H-TPP molecule (+/0.03 a.u.) are displayed in red/pink and green/yellow. The blue/red rectangles represent the width of the bands formed from the overlap of metal bands with the 2H-TPP HOMO/LUMO. On Cu some of the metal/LUMO bands are off the scale of this figure, as denoted by the dashed line. Note that the bandwidths of the metals extend to higher/lower energies. 


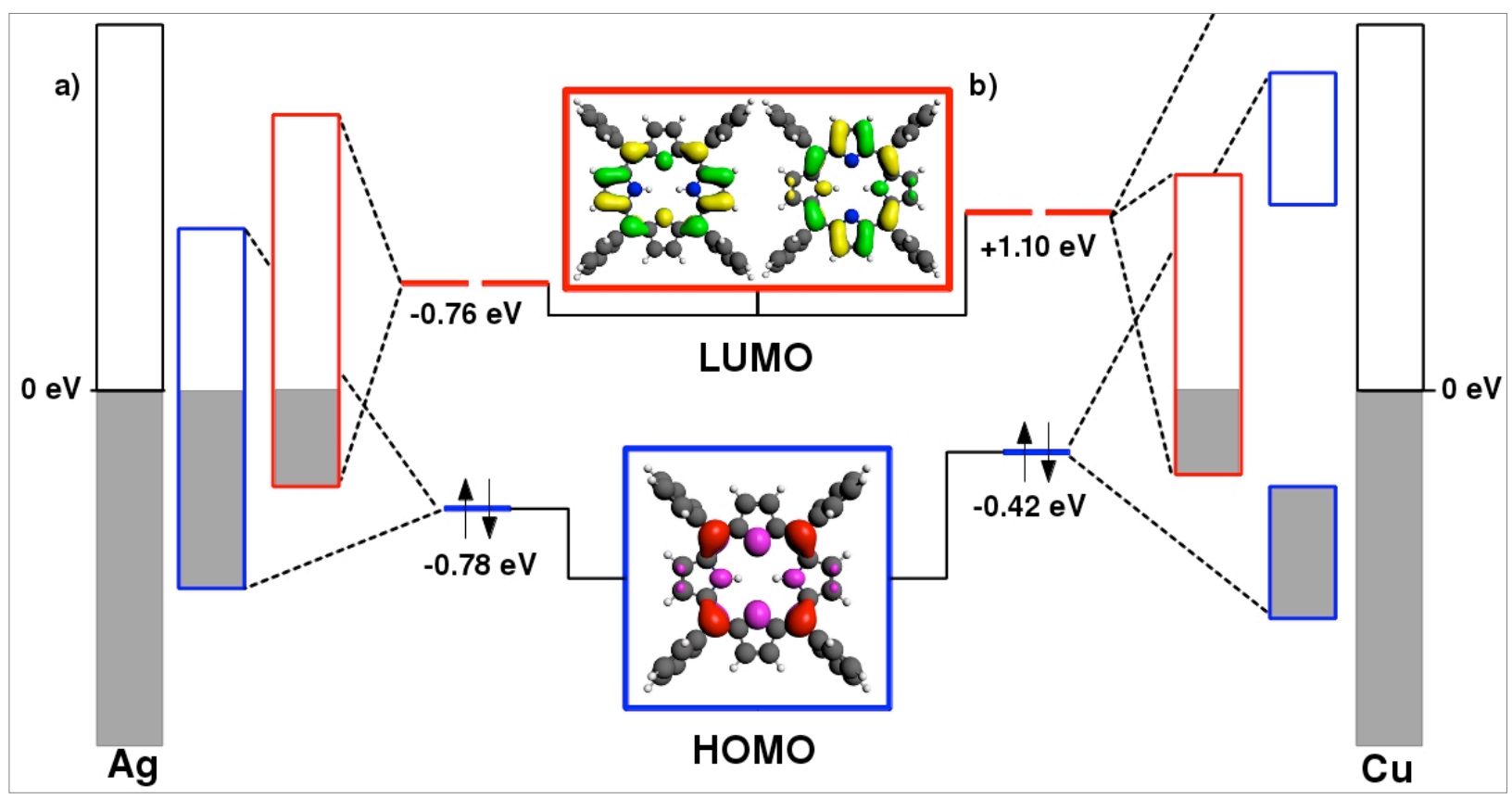




\section{Section 5: Coordinates}

S1-Adjacent 2H-TPP Dimer

$\mathrm{E}=-1043.98775848 \mathrm{eV}$ Symmetry: $\mathrm{C}_{2 \mathrm{v}}$

\begin{tabular}{|c|c|c|c|}
\hline $\mathrm{H}$ & -14.632016 & -6.294225 & 0.013682 \\
\hline $\mathrm{H}$ & -14.632016 & 6.294225 & 0.013682 \\
\hline $\mathrm{C}$ & -13.855608 & -5.525492 & 0.006242 \\
\hline $\mathrm{C}$ & -13.855608 & 5.525492 & 0.006242 \\
\hline $\mathrm{H}$ & -13.467074 & 1.347669 & 0.173646 \\
\hline $\mathrm{H}$ & -13.467074 & -1.347669 & 0.173646 \\
\hline $\mathrm{H}$ & -14.458660 & -4.700141 & -1.906099 \\
\hline $\mathrm{H}$ & -14.458660 & 4.700141 & -1.906099 \\
\hline $\mathrm{C}$ & -13.759877 & -4.629054 & -1.069030 \\
\hline $\mathrm{C}$ & -13.759877 & 4.629054 & -1.069030 \\
\hline $\mathrm{C}$ & -12.947725 & -5.428541 & 1.071674 \\
\hline $\mathrm{C}$ & -12.947725 & 5.428541 & 1.071674 \\
\hline $\mathrm{H}$ & -13.017334 & -6.119126 & 1.915801 \\
\hline $\mathrm{H}$ & -13.017334 & 6.119126 & 1.915801 \\
\hline $\mathrm{C}$ & -12.609272 & -0.688133 & 0.091867 \\
\hline $\mathrm{C}$ & -12.609272 & 0.688133 & 0.091867 \\
\hline $\mathrm{H}$ & -12.686374 & -2.943943 & -1.912285 \\
\hline $\mathrm{H}$ & -12.686374 & 2.943943 & -1.912285 \\
\hline $\mathrm{C}$ & -12.764706 & -3.642393 & -1.076429 \\
\hline $\mathrm{C}$ & -12.764706 & 3.642393 & -1.076429 \\
\hline $\mathrm{C}$ & -11.952706 & -4.441989 & 1.061912 \\
\hline $\mathrm{C}$ & -11.952706 & 4.441989 & 1.061912 \\
\hline $\mathrm{H}$ & -11.246395 & -4.362053 & 1.890813 \\
\hline $\mathrm{H}$ & -11.246395 & 4.362053 & 1.890813 \\
\hline $\mathrm{C}$ & -11.848226 & -3.535428 & -0.012034 \\
\hline $\mathrm{C}$ & -11.848226 & 3.535428 & -0.012034 \\
\hline $\mathrm{C}$ & -11.246159 & 1.136555 & -0.005931 \\
\hline $\mathrm{C}$ & -11.246159 & -1.136555 & -0.005931 \\
\hline $\mathrm{C}$ & -10.791091 & -2.472192 & -0.016819 \\
\hline $\mathrm{C}$ & -10.791091 & 2.472192 & -0.016819 \\
\hline $\mathrm{N}$ & -10.462042 & 0.000000 & -0.060579 \\
\hline $\mathrm{H}$ & -9.683937 & -5.131056 & -0.226769 \\
\hline $\mathrm{H}$ & -9.683937 & 5.131056 & -0.226769 \\
\hline $\mathrm{H}$ & -9.444133 & 0.000000 & -0.071925 \\
\hline $\mathrm{C}$ & -9.432382 & -2.875554 & -0.027725 \\
\hline $\mathrm{C}$ & -9.432382 & 2.875554 & -0.027725 \\
\hline $\mathrm{C}$ & -9.018772 & -4.277214 & -0.133434 \\
\hline $\mathrm{C}$ & -9.018772 & 4.277214 & -0.133434 \\
\hline $\mathrm{N}$ & -8.339417 & -2.041025 & 0.030416 \\
\hline $\mathrm{N}$ & -8.339417 & 2.041025 & 0.030416 \\
\hline $\mathrm{C}$ & -7.657112 & -4.276954 & -0.123939 \\
\hline $\mathrm{C}$ & -7.657112 & 4.276954 & -0.123939 \\
\hline $\mathrm{C}$ & -7.245578 & -2.875124 & -0.015566 \\
\hline C & -7.245578 & 2.875124 & -0.015566 \\
\hline $\mathrm{H}$ & -7.234471 & 0.000000 & -0.048785 \\
\hline
\end{tabular}

\begin{tabular}{|c|c|c|c|}
\hline $\mathrm{H}$ & -6.990332 & -5.130155 & \\
\hline $\mathrm{H}$ & -6.990332 & & \\
\hline & -6.216737 & & \\
\hline & & -2.471290 & \\
\hline & -5.887630 & & \\
\hline 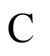 & -5.43 & & \\
\hline 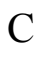 & -5.432601 & & \\
\hline & -4.82 & -3.5 & \\
\hline $\mathrm{C}$ & -4.82 & & \\
\hline 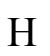 & -4.0 & -2.9 & \\
\hline & -4.0 & & \\
\hline 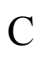 & -3.92 & -3.6 & \\
\hline $\mathrm{C}$ & -3.9 & & \\
\hline $\mathrm{C}$ & -4.7 & -4 & \\
\hline $\mathrm{C}$ & & & \\
\hline 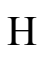 & -5.4 & -4 & \\
\hline & -5.4 & & \\
\hline$C$ & -4.0 & -0 & \\
\hline 0 & -4.0 & & \\
\hline $\mathrm{H}$ & -2.2 & -4 & \\
\hline $\mathrm{H}$ & -2.2 & & \\
\hline $\mathrm{C}$ & -2.9 & -4 & \\
\hline $\mathrm{C}$ & -2.9 & & \\
\hline $\mathrm{C}$ & & & \\
\hline $\mathrm{C}$ & -3.7 & & \\
\hline $\mathrm{H}$ & -3.6 & -6 . & \\
\hline . & -3.6 & & \\
\hline . & -3.2 & -1.2 & \\
\hline H & -3.2 & & \\
\hline 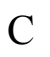 & -2.8 & & \\
\hline S & & & \\
\hline $\mathrm{H}$ & -2.0 & & \\
\hline 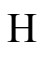 & -2.0 & & \\
\hline 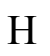 & 2.0 & & \\
\hline$-\gamma$ & 2.0 & & \\
\hline $\mathrm{C}$ & 2.82 & -5. & \\
\hline 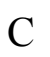 & 2.82 & & \\
\hline $\mathrm{H}$ & 3.2 & & \\
\hline-3 & 3.21 & -1.3 & \\
\hline 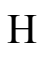 & 3.6 & -6. & \\
\hline 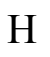 & 3.6 & & \\
\hline . & 3.72 & -5.4 & \\
\hline $\mathrm{C}$ & 3.72 & & \\
\hline 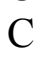 & 2.92 & -4. & \\
\hline $\mathrm{C}$ & 2.92 & & \\
\hline 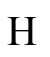 & 2.234924 & -4.7 & \\
\hline $\mathrm{H}$ & 2.234924 & & \\
\hline & 4.069503 & -0.688135 & 0.114 \\
\hline
\end{tabular}




\begin{tabular}{|c|c|c|c|c|c|c|c|}
\hline $\mathrm{C}$ & 4.069503 & 0.688135 & 0.114180 & $\mathrm{H}$ & 13.017334 & -6.119126 & 1.915801 \\
\hline $\mathrm{H}$ & 5.417917 & -4.327169 & 1.943165 & $\mathrm{H}$ & 13.017334 & 6.119126 & 1.915801 \\
\hline $\mathrm{H}$ & 5.417917 & 4.327169 & 1.943165 & $\mathrm{C}$ & 12.947725 & -5.428541 & 1.071674 \\
\hline $\mathrm{C}$ & 4.717910 & -4.421836 & 1.109777 & $\mathrm{C}$ & 12.947725 & 5.428541 & 1.071674 \\
\hline $\mathrm{C}$ & 4.717910 & 4.421836 & 1.109777 & $\mathrm{C}$ & 13.759877 & -4.629054 & -1.069030 \\
\hline $\mathrm{C}$ & 3.920522 & -3.658534 & -1.047367 & $\mathrm{C}$ & 13.759877 & 4.629054 & -1.069030 \\
\hline $\mathrm{C}$ & 3.920522 & 3.658534 & -1.047367 & $\mathrm{H}$ & 14.458660 & -4.700141 & -1.90609 \\
\hline $\mathrm{H}$ & 4.003367 & -2.972578 & -1.892724 & $\mathrm{H}$ & 14.458660 & 4.700141 & -1.90609 \\
\hline $\mathrm{H}$ & 4.003367 & 2.972578 & -1.892724 & $\mathrm{H}$ & 13.467074 & -1.347669 & 0.173646 \\
\hline $\mathrm{C}$ & 4.829672 & -3.534150 & 0.021180 & $\mathrm{H}$ & 13.467074 & 1.347669 & 0.173646 \\
\hline $\mathrm{C}$ & 4.829672 & 3.534150 & 0.021180 & $\mathrm{C}$ & 13.855608 & -5.525492 & 0.006242 \\
\hline $\mathrm{C}$ & 5.432601 & 1.136302 & 0.017972 & $\mathrm{C}$ & 13.855608 & 5.525492 & 0.006242 \\
\hline $\mathrm{C}$ & 5.432601 & -1.136302 & 0.017972 & $\mathrm{H}$ & 14.632016 & -6.294225 & 0.013682 \\
\hline $\mathrm{C}$ & 5.887630 & -2.471290 & 0.006142 & $\mathrm{H}$ & 14.632016 & 6.294225 & 0.01368 \\
\hline $\mathrm{C}$ & 5.887630 & 2.471290 & 0.006142 & & & & \\
\hline $\mathrm{N}$ & 6.216737 & 0.000000 & -0.035577 & \multicolumn{4}{|c|}{ S2-Sandwich 2H-TPP Dimer } \\
\hline $\mathrm{H}$ & 6.990332 & -5.130155 & -0.207176 & \multicolumn{4}{|c|}{$\mathrm{E}=-1045.07165541 \mathrm{eV}$} \\
\hline $\mathrm{H}$ & 6.990332 & 5.130155 & -0.207176 & $\mathrm{C}$ & -3.038613 & 2.742607 & 2.470483 \\
\hline $\mathrm{H}$ & 7.234471 & 0.000000 & -0.048785 & $\mathrm{C}$ & -3.454285 & 2.946468 & 1.136601 \\
\hline $\mathrm{C}$ & 7.245578 & -2.875124 & -0.015566 & $\mathrm{C}$ & -1.755541 & 2.275154 & 2.858180 \\
\hline $\mathrm{C}$ & 7.245578 & 2.875124 & -0.015566 & $\mathrm{C}$ & -4.680716 & 3.547237 & 0.688350 \\
\hline $\mathrm{C}$ & 7.657112 & -4.276954 & -0.123939 & $\mathrm{C}$ & -4.680716 & 3.547237 & -0.688350 \\
\hline $\mathrm{C}$ & 7.657112 & 4.276954 & -0.123939 & $\mathrm{C}$ & -3.454285 & 2.946468 & -1.136601 \\
\hline $\mathrm{N}$ & 8.339417 & -2.041025 & 0.030416 & $\mathrm{C}$ & -1.408678 & & 4.238644 \\
\hline $\mathrm{N}$ & 8.339417 & 2.041025 & 0.030416 & $\mathrm{C}$ & -0.078398 & 1.640462 & 4.236598 \\
\hline $\mathrm{C}$ & 9.018772 & -4.277214 & -0.133434 & $\mathrm{C}$ & 0.376962 & 1.793599 & 2.852954 \\
\hline $\mathrm{C}$ & 9.018772 & 4.277214 & -0.133434 & $\mathrm{~N}$ & -2.744497 & 2.610311 & 0.000000 \\
\hline $\mathrm{C}$ & 9.432382 & -2.875554 & -0.027725 & $\mathrm{H}$ & -1.788008 & 2.258651 & 0.000000 \\
\hline $\mathrm{C}$ & 9.432382 & 2.875554 & -0.027725 & $\mathrm{H}$ & -5.444064 & 3.949786 & 1.345137 \\
\hline $\mathrm{H}$ & 9.444133 & 0.000000 & -0.071925 & $\mathrm{H}$ & -5.444064 & 3.949786 & -1.345137 \\
\hline $\mathrm{H}$ & 9.683937 & -5.131056 & -0.226769 & $\mathrm{~N}$ & -0.669077 & 2.131529 & 2.025456 \\
\hline $\mathrm{H}$ & 9.683937 & 5.131056 & -0.226769 & $\mathrm{H}$ & -2.102342 & 1.874004 & 5.072249 \\
\hline $\mathrm{N}$ & 10.462042 & 0.000000 & -0.060579 & $\mathrm{H}$ & 0.534698 & & 5.066791 \\
\hline $\mathrm{C}$ & 10.791091 & -2.472192 & -0.016819 & $\mathrm{C}$ & -3.038613 & 2.742607 & -2.470483 \\
\hline $\mathrm{C}$ & 10.791091 & 2.472192 & -0.016819 & $\mathrm{C}$ & -1.755541 & 2.275154 & -2.858180 \\
\hline $\mathrm{C}$ & 11.246159 & -1.136555 & -0.005931 & $\mathrm{C}$ & -1.408678 & 1.930655 & -4.238644 \\
\hline $\mathrm{C}$ & 11.246159 & 1.136555 & -0.005931 & $\mathrm{C}$ & -0.078398 & 1.640462 & -4.236598 \\
\hline $\mathrm{C}$ & 11.848226 & -3.535428 & -0.012034 & $\mathrm{C}$ & 0.376962 & 1.793599 & -2.852954 \\
\hline $\mathrm{C}$ & 11.848226 & 3.535428 & -0.012034 & $\mathrm{~N}$ & -0.669077 & 2.131529 & -2.025456 \\
\hline $\mathrm{H}$ & 11.246395 & -4.362053 & 1.890813 & $\mathrm{H}$ & -2.102342 & 1.874004 & -5.072249 \\
\hline $\mathrm{H}$ & 11.246395 & 4.362053 & 1.890813 & $\mathrm{H}$ & 0.534698 & 1.304006 & -5.066791 \\
\hline $\mathrm{C}$ & 11.952706 & -4.441989 & 1.061912 & $\mathrm{C}$ & 1.736363 & 1.648687 & 2.470138 \\
\hline $\mathrm{C}$ & 11.952706 & 4.441989 & 1.061912 & $\mathrm{C}$ & 3.564553 & 1.554078 & 0.688244 \\
\hline $\mathrm{C}$ & 12.764706 & -3.642393 & -1.076429 & $\mathrm{C}$ & 3.564553 & 1.554078 & -0.688244 \\
\hline $\mathrm{C}$ & 12.764706 & 3.642393 & -1.076429 & $\mathrm{C}$ & 2.199121 & 1.587706 & -1.137443 \\
\hline $\mathrm{H}$ & 12.686374 & -2.943943 & -1.912285 & $\mathrm{~N}$ & 1.413468 & 1.589976 & 0.000000 \\
\hline $\mathrm{H}$ & 12.686374 & 2.943943 & -1.912285 & $\mathrm{H}$ & 4.427035 & 1.556618 & -1.345752 \\
\hline $\mathrm{C}$ & 12.609272 & -0.688133 & 0.091867 & $\mathrm{C}$ & 1.736363 & 1.648687 & -2.470138 \\
\hline $\mathrm{C}$ & 12.609272 & 0.688133 & 0.091867 & $\mathrm{C}$ & 2.199121 & 1.587706 & 1.137443 \\
\hline
\end{tabular}




\begin{tabular}{|c|c|c|c|c|c|c|}
\hline 4.427035 & 1.556618 & 1.345752 & $\mathrm{C}$ & -3.564553 & -1.554078 & 0.688244 \\
\hline 0.404131 & 1.729419 & 0.000000 & $\mathrm{C}$ & -3.564553 & -1.554078 & -0.688244 \\
\hline 2.763464 & 1.650481 & 3.559518 & $\mathrm{C}$ & -2.199121 & -1.587706 & -1.137443 \\
\hline 2.800249 & 2.722829 & 4.477910 & $\mathrm{C}$ & 0.078398 & -1.640462 & 4.236598 \\
\hline 3.707615 & 0.614939 & 3.702444 & $\mathrm{C}$ & 1.408678 & -1.930655 & 4.238644 \\
\hline 3.747391 & 2.755301 & 5.509187 & $\mathrm{C}$ & 1.755541 & -2.275154 & 2.858180 \\
\hline 4.652626 & 0.643506 & 4.736032 & $\mathrm{~N}$ & -1.413468 & -1.589976 & 0.000000 \\
\hline 4.677560 & 1.713133 & 5.643185 & $\mathrm{H}$ & -0.404131 & -1.729419 & 0.000000 \\
\hline 2.076016 & 3.533050 & 4.371231 & $\mathrm{H}$ & -4.427035 & -1.556618 & 1.345752 \\
\hline 3.675845 & -0.224072 & 3.009162 & $\mathrm{H}$ & -4.427035 & -1.556618 & -1.345752 \\
\hline 3.760503 & 3.597021 & 6.205896 & $\mathrm{~N}$ & 0.669077 & -2.131529 & 2.025456 \\
\hline 5.355845 & -0.183454 & 4.843673 & $\mathrm{H}$ & -0.534698 & -1.304006 & 5.066791 \\
\hline 5.413832 & 1.731833 & 6.450847 & $\mathrm{H}$ & 2.102342 & -1.874004 & 5.072249 \\
\hline 2.763464 & 1.650481 & -3.559518 & $\mathrm{C}$ & -1.736363 & -1.648687 & -2.470138 \\
\hline 2.800249 & 2.722829 & -4.477910 & $\mathrm{C}$ & -0.376962 & -1.793599 & -2.852954 \\
\hline 3.707615 & 0.614939 & -3.702444 & $\mathrm{C}$ & 0.078398 & -1.640462 & -4.236598 \\
\hline 3.747391 & 2.755301 & -5.509187 & $\mathrm{C}$ & 1.408678 & -1.930655 & -4.238644 \\
\hline 4.652626 & 0.643506 & -4.736032 & $\mathrm{C}$ & 1.755541 & -2.275154 & -2.858180 \\
\hline 4.677560 & 1.713133 & -5.643185 & $\mathrm{~N}$ & 0.669077 & -2.131529 & -2.025456 \\
\hline 2.076016 & 3.533050 & -4.371231 & $\mathrm{H}$ & -0.534698 & -1.304006 & -5.066791 \\
\hline 3.675845 & -0.224072 & -3.009162 & $\mathrm{H}$ & 2.102342 & -1.874004 & -5.072249 \\
\hline 3.760503 & 3.597021 & -6.205896 & $\mathrm{C}$ & 3.038613 & -2.742607 & 2.470483 \\
\hline 5.355845 & -0.183454 & -4.843673 & $\mathrm{C}$ & 4.680716 & -3.547237 & 0.688350 \\
\hline 5.413832 & 1.731833 & -6.450847 & $\mathrm{C}$ & 4.680716 & -3.547237 & -0.688350 \\
\hline-4.023894 & 3.090569 & 3.541163 & $\mathrm{C}$ & 3.454285 & -2.946468 & -1.136601 \\
\hline-3.677966 & 3.997679 & 4.565595 & $\mathrm{~N}$ & 2.744497 & -2.610311 & 0.000000 \\
\hline-5.322581 & 2.541491 & 3.549994 & $\mathrm{H}$ & 5.444064 & -3.949786 & -1.345137 \\
\hline-4.595642 & 4.335700 & 5.567857 & $\mathrm{C}$ & 3.038613 & -2.742607 & -2.470483 \\
\hline-6.243284 & 2.879216 & 4.549526 & $\mathrm{C}$ & 3.454285 & -2.946468 & 1.136601 \\
\hline-5.883016 & 3.776958 & 5.565822 & $\mathrm{H}$ & 5.444064 & -3.949786 & 1.345137 \\
\hline-2.681423 & 4.443954 & 4.560140 & $\mathrm{H}$ & 1.788008 & -2.258651 & 0.000000 \\
\hline-5.600958 & 1.834475 & 2.767149 & $\mathrm{C}$ & 4.023894 & -3.090569 & 3.541163 \\
\hline-4.306953 & 5.045377 & 6.346558 & $\mathrm{C}$ & 5.322581 & -2.541491 & 3.549994 \\
\hline-7.240827 & 2.433855 & 4.539081 & $\mathrm{C}$ & 3.677966 & -3.997679 & 4.565595 \\
\hline-6.599639 & 4.042275 & 6.346667 & $\mathrm{C}$ & 6.243284 & -2.879216 & 4.549526 \\
\hline-4.023894 & 3.090569 & -3.541163 & $\mathrm{C}$ & 4.595642 & -4.335700 & 5.567857 \\
\hline-3.677966 & 3.997679 & -4.565595 & $\mathrm{C}$ & 5.883016 & -3.776958 & 5.565822 \\
\hline-5.322581 & 2.541491 & -3.549994 & $\mathrm{H}$ & 5.600958 & -1.834475 & 2.767149 \\
\hline-4.595642 & 4.335700 & -5.567857 & $\mathrm{H}$ & 2.681423 & -4.443954 & 4.560140 \\
\hline-6.243284 & 2.879216 & -4.549526 & $\mathrm{H}$ & 7.240827 & -2.433855 & 4.539081 \\
\hline-5.883016 & 3.776958 & -5.565822 & $\mathrm{H}$ & 4.306953 & -5.045377 & 6.346558 \\
\hline-2.681423 & 4.443954 & -4.560140 & $\mathrm{H}$ & 6.599639 & -4.042275 & 6.346667 \\
\hline-5.600958 & 1.834475 & -2.767149 & $\mathrm{C}$ & 4.023894 & -3.090569 & -3.541163 \\
\hline-4.306953 & 5.045377 & -6.346558 & $\mathrm{C}$ & 5.322581 & -2.541491 & -3.549994 \\
\hline-7.240827 & 2.433855 & -4.539081 & $\mathrm{C}$ & 3.677966 & -3.997679 & -4.565595 \\
\hline-6.599639 & 4.042275 & -6.346667 & $\mathrm{C}$ & 6.243284 & -2.879216 & -4.549526 \\
\hline-1.736363 & -1.648687 & 2.470138 & $\mathrm{C}$ & 4.595642 & -4.335700 & -5.567857 \\
\hline-2.199121 & -1.587706 & 1.137443 & $\mathrm{C}$ & 5.883016 & -3.776958 & -5.565822 \\
\hline-0.376962 & -1.793599 & 2.852954 & $\mathrm{H}$ & 5.600958 & -1.834475 & -2.767149 \\
\hline
\end{tabular}




$\begin{array}{lrrr}\mathrm{H} & 2.681423 & -4.443954 & -4.560140 \\ \mathrm{H} & 7.240827 & -2.433855 & -4.539081 \\ \mathrm{H} & 4.306953 & -5.045377 & -6.346558 \\ \mathrm{H} & 6.599639 & -4.042275 & -6.346667 \\ \mathrm{C} & -2.763464 & -1.650481 & 3.559518 \\ \mathrm{C} & -3.707615 & -0.614939 & 3.702444 \\ \mathrm{C} & -2.800249 & -2.722829 & 4.477910 \\ \mathrm{C} & -4.652626 & -0.643506 & 4.736032 \\ \mathrm{C} & -3.747391 & -2.755301 & 5.509187 \\ \mathrm{C} & -4.677560 & -1.713133 & 5.643185 \\ \mathrm{H} & -3.675845 & 0.224072 & 3.009162 \\ \mathrm{H} & -2.076016 & -3.533050 & 4.371231 \\ \mathrm{H} & -5.355845 & 0.183454 & 4.843673 \\ \mathrm{H} & -3.760503 & -3.597021 & 6.205896 \\ \mathrm{H} & -5.413832 & -1.731833 & 6.450847 \\ \mathrm{C} & -2.763464 & -1.650481 & -3.559518 \\ \mathrm{C} & -3.707615 & -0.614939 & -3.702444 \\ \mathrm{C} & -2.800249 & -2.722829 & -4.477910 \\ \mathrm{C} & -4.652626 & -0.643506 & -4.736032 \\ \mathrm{C} & -3.747391 & -2.755301 & -5.509187 \\ \mathrm{C} & -4.677560 & -1.713133 & -5.643185 \\ \mathrm{H} & -3.675845 & 0.224072 & -3.009162 \\ \mathrm{H} & -2.076016 & -3.533050 & -4.371231 \\ \mathrm{H} & -5.355845 & 0.183454 & -4.843673 \\ \mathrm{H} & -3.760503 & -3.597021 & -6.205896 \\ \mathrm{H} & -5.413832 & -1.731833 & -6.450847\end{array}$

S3- Ag(111) 64-Benzene

\begin{tabular}{cccc}
\multicolumn{2}{c}{$\mathrm{E}=-183.74769746 \mathrm{eV}$} & \multicolumn{2}{c}{ Symmetry: $\mathrm{C}_{3 \mathrm{v}}$} \\
$\mathrm{Ag}$ & -6.672409 & 2.889236 & -1.293224 \\
$\mathrm{Ag}$ & -6.672409 & -2.889236 & -1.293224 \\
$\mathrm{Ag}$ & 5.838356 & -4.333857 & -1.293224 \\
$\mathrm{Ag}$ & 5.838356 & 4.333857 & -1.293224 \\
$\mathrm{Ag}$ & 0.834052 & -7.223094 & -1.293224 \\
$\mathrm{Ag}$ & 0.834052 & 7.223094 & -1.293224 \\
$\mathrm{Ag}$ & -6.672411 & 0.000000 & -1.293222 \\
$\mathrm{Ag}$ & 3.336206 & -5.778478 & -1.293222 \\
$\mathrm{Ag}$ & 3.336206 & 5.778478 & -1.293222 \\
$\mathrm{Ag}$ & -4.170257 & 1.444622 & -1.293220 \\
$\mathrm{Ag}$ & -4.170257 & -1.444622 & -1.293220 \\
$\mathrm{Ag}$ & 3.336207 & -2.889238 & -1.293220 \\
$\mathrm{Ag}$ & 3.336207 & 2.889238 & -1.293220 \\
$\mathrm{Ag}$ & 0.834049 & -4.333859 & -1.293220 \\
$\mathrm{Ag}$ & 0.834049 & 4.333859 & -1.293220 \\
$\mathrm{Ag}$ & -1.668100 & 0.000000 & -1.293216 \\
$\mathrm{Ag}$ & 0.834050 & -1.444617 & -1.293216
\end{tabular}

\begin{tabular}{|c|c|c|c|}
\hline & 0.834050 & 1.444617 & -1.293216 \\
\hline $\mathrm{Ag}$ & -1.668102 & -2.889237 & -1.293214 \\
\hline g & -1.668102 & 2.889237 & -1.293214 \\
\hline $\mathrm{Ag}$ & 3.336203 & 0.000000 & -1.293214 \\
\hline$g$ & -1.668100 & -5.778479 & -1.293212 \\
\hline $\mathrm{Ag}$ & -1.668100 & 5.778479 & -1.293212 \\
\hline $\mathrm{g}$ & -4.170260 & -4.333857 & -1.293212 \\
\hline $\mathrm{g}$ & -4.170260 & 4.333857 & -1.293212 \\
\hline$g$ & 5.838360 & 1.444622 & -1.293212 \\
\hline$g$ & 5.838360 & -1.444622 & -1.293212 \\
\hline g & -7.787319 & 4.597414 & 0.982917 \\
\hline g & -7.787319 & -4.597414 & 0.982917 \\
\hline g & 7.875137 & -4.445310 & 0.982917 \\
\hline$g$ & 7.875137 & 4.445310 & 0.982917 \\
\hline$g$ & -0.087817 & -9.042723 & 0.982917 \\
\hline $\mathrm{Ag}$ & -0.087817 & 9.042723 & 0.982917 \\
\hline $\mathrm{Ag}$ & -7.954438 & 1.518828 & 1.202254 \\
\hline $\mathrm{Ag}$ & -7.954438 & -1.518828 & 1.202254 \\
\hline g & 5.292563 & -6.129331 & 1.202254 \\
\hline $\mathrm{g}$ & 5.292563 & 6.129331 & 1.202254 \\
\hline g & 2.661875 & -7.648160 & 1.202254 \\
\hline $\mathrm{Ag}$ & 2.661875 & 7.648160 & 1.202254 \\
\hline g & -5.248020 & 3.062867 & 1.676706 \\
\hline $\mathrm{Ag}$ & -5.248020 & -3.062867 & $1.6^{\circ}$ \\
\hline $\mathrm{Ag}$ & 5.276530 & -3.013485 & 1.676706 \\
\hline $\mathrm{Ag}$ & 5.276530 & 3.0 & 1.676706 \\
\hline Ag & -0.028511 & -6.076352 & 5706 \\
\hline $\mathrm{Ag}$ & -0.028511 & 6.076352 & 5706 \\
\hline $\mathrm{Ag}$ & -5.295288 & 0.000000 & 1.665041 \\
\hline $\mathrm{Ag}$ & 2.647644 & -4.585854 & 1.665041 \\
\hline $\mathrm{Ag}$ & 2.647644 & 4.585854 & 1.665041 \\
\hline $\mathrm{Ag}$ & -2.699858 & 1.561404 & 1.468911 \\
\hline $\mathrm{Ag}$ & -2.699858 & -1.561404 & 1.468911 \\
\hline $\mathrm{Ag}$ & 2.702144 & -1.557444 & 1.468911 \\
\hline $\mathrm{Ag}$ & 2.702144 & 1.557444 & 1.468911 \\
\hline $\mathrm{Ag}$ & -0.002286 & -3.118847 & 1.468911 \\
\hline $\mathrm{Ag}$ & -0.002286 & 3.118847 & 1.468911 \\
\hline $\mathrm{Ag}$ & -2.651321 & -4.592222 & 1.669296 \\
\hline $\mathrm{Ag}$ & -2.651321 & 4.592222 & 1.669296 \\
\hline $\mathrm{Ag}$ & 5.302642 & 0.000000 & 1.669296 \\
\hline $\mathrm{Ag}$ & 0.000000 & 0.000000 & 1.312384 \\
\hline $\mathrm{Ag}$ & -2.721867 & -7.678530 & 0.691063 \\
\hline $\mathrm{Ag}$ & -2.721867 & 7.678530 & 0.691063 \\
\hline $\mathrm{Ag}$ & -5.288869 & -6.196471 & 0.691063 \\
\hline $\mathrm{Ag}$ & -5.288869 & 6.196471 & 0.691063 \\
\hline $\mathrm{Ag}$ & 8.010735 & 1.482059 & 0.691063 \\
\hline $\mathrm{Ag}$ & 8.010735 & -1.482059 & 0.691063 \\
\hline $\mathrm{C}$ & -1.217347 & 0.702723 & 4.528152 \\
\hline $\mathrm{C}$ & -1.217347 & -0.702723 & 4.528152 \\
\hline
\end{tabular}




$\begin{array}{lrrr}\mathrm{C} & 0.000098 & -1.405615 & 4.528152 \\ \mathrm{C} & 1.217250 & -0.702892 & 4.528152 \\ \mathrm{C} & 1.217250 & 0.702892 & 4.528152 \\ \mathrm{C} & 0.000098 & 1.405615 & 4.528152 \\ \mathrm{H} & -2.163502 & 1.249690 & 4.528808 \\ \mathrm{H} & -2.163502 & -1.249690 & 4.528808 \\ \mathrm{H} & -0.000512 & -2.498492 & 4.528808 \\ \mathrm{H} & 2.164014 & -1.248802 & 4.528808 \\ \mathrm{H} & 2.164014 & 1.248802 & 4.528808 \\ \mathrm{H} & -0.000512 & 2.498492 & 4.528808\end{array}$

S4- Ag(111)_166-Benzene

$\mathrm{E}=-372.89129933 \mathrm{eV}$ Symmetry: $\mathrm{C}_{3 \mathrm{v}}$

$\begin{array}{lccl}\mathrm{Ag} & -0.834052 & 1.444620 & -1.641278 \\ \mathrm{Ag} & -0.834052 & -1.444620 & -1.641278 \\ \mathrm{Ag} & 1.668103 & 0.000000 & -1.641278 \\ \mathrm{Ag} & -0.834055 & 10.112322 & -1.641277 \\ \mathrm{Ag} & -8.340500 & 5.778474 & -1.641277 \\ \mathrm{Ag} & -0.834055 & -10.112322 & -1.641277 \\ \mathrm{Ag} & 9.174555 & -4.333848 & -1.641277 \\ \mathrm{Ag} & -8.340500 & -5.778474 & -1.641277 \\ \mathrm{Ag} & 9.174555 & 4.333848 & -1.641277 \\ \mathrm{Ag} & -0.834054 & 4.333856 & -1.641274 \\ \mathrm{Ag} & -3.336202 & 2.889240 & -1.641274 \\ \mathrm{Ag} & -0.834054 & -4.333856 & -1.641274 \\ \mathrm{Ag} & 4.170256 & -1.444616 & -1.641274 \\ \mathrm{Ag} & -3.336202 & -2.889240 & -1.641274 \\ \mathrm{Ag} & 4.170256 & 1.444616 & -1.641274 \\ \mathrm{Ag} & -0.834054 & 13.001559 & -1.641274 \\ \mathrm{Ag} & -10.842654 & 7.223092 & -1.641274 \\ \mathrm{Ag} & -0.834054 & -13.001559 & -1.641274 \\ \mathrm{Ag} & 11.676708 & -5.778467 & -1.641274 \\ \mathrm{Ag} & -10.842654 & -7.223092 & -1.641274 \\ \mathrm{Ag} & 11.676708 & 5.778467 & -1.641274 \\ \mathrm{Ag} & -3.336213 & 8.667703 & -1.641273 \\ \mathrm{Ag} & -5.838345 & 7.223097 & -1.641273 \\ \mathrm{Ag} & -3.336213 & -8.667703 & -1.641273 \\ \mathrm{Ag} & 9.174558 & -1.444606 & -1.641273 \\ \mathrm{Ag} & -5.838345 & -7.223097 & -1.641273 \\ \mathrm{Ag} & 9.174558 & 1.444606 & -1.641273 \\ \mathrm{Ag} & -0.834054 & 7.223084 & -1.641271 \\ \mathrm{Ag} & -5.838348 & 4.333854 & -1.641271 \\ \mathrm{Ag} & -0.834054 & -7.223084 & -1.641271 \\ \mathrm{Ag} & 6.672402 & -2.889230 & -1.641271 \\ \mathrm{Ag} & -5.838348 & -4.333854 & -1.641271 \\ \mathrm{Ag} & 6.672402 & 2.889230 & -1.641271 \\ \mathrm{Ag} & -3.336203 & 11.556930 & -1.641269 \\ \mathrm{Ag} & -8.340494 & 8.667702 & -1.641269 \\ \mathrm{Ag} & -3.336203 & -11.556930 & -1.641269\end{array}$

\begin{tabular}{|c|c|c|c|}
\hline & 11.676697 & -2.889229 & 269 \\
\hline $\mathrm{g}$ & -8.340494 & -8.667702 & -1.641269 \\
\hline$g$ & 11.676697 & 2.889229 & 269 \\
\hline$\sigma$ & -3.336206 & 5.778479 & -1.641266 \\
\hline & -3.336206 & -5.778479 & -1.641266 \\
\hline & 6.672412 & 0.000000 & -1.641266 \\
\hline & -5.838351 & 10.112321 & 41265 \\
\hline & -5.838351 & -10.112321 & 1265 \\
\hline & 11.676702 & 0.000000 & -1.6 \\
\hline & -3.336201 & 0.000000 & -1.6 \\
\hline & 1.668100 & 2.889235 & -1.6 \\
\hline & 1.668100 & -2.889235 & -1 \\
\hline & -5.838359 & -1.444619 & \\
\hline & 4.170256 & 4.3 & -1.6 \\
\hline & -5.8 & 1.4 & -1. \\
\hline & 1.668103 & $5.7^{\prime}$ & -1.6 \\
\hline & 4.170256 & -4.333858 & -1 \\
\hline & 1.6 & -5.7 & -1 \\
\hline & -8.340507 & -2.889239 & -1.6 \\
\hline & 6.672408 & 5.778472 & -1.6 \\
\hline & -8.340507 & 2.889239 & -1.6 \\
\hline & 1.668099 & 8.6677 & -1.6 \\
\hline & 6.672408 & -5.778472 & -1.6 \\
\hline & 1.66 & -8.667711 & -1 \\
\hline & -8.3 & 0.0 & -1 \\
\hline & 4.170254 & 7.2230 & -1.6 \\
\hline Ig & 4.17 & -7.2231 & -1.6 \\
\hline & -10.8 & -4.333 & 250 \\
\hline$g$ & $9.1^{\prime}$ & 7.223091 & -1.6 \\
\hline & -10.842655 & 4.333 & -1 \\
\hline & 1.668105 & 11.556939 & -1 \\
\hline & 9.174550 & -7.223091 & -1.6 \\
\hline $\mathrm{Ag}$ & 1.668105 & -11.556 & -1 . \\
\hline & -10.842656 & -1.444620 & 246 \\
\hline & 6.672406 & 8.667705 & -1.6 \\
\hline & -10.842656 & 1.444 & -1. \\
\hline & 4.170250 & 10.112325 & -1.6 \\
\hline $\mathrm{Ag}$ & 6.67 & -8.667705 & -1.6 \\
\hline & 4.170250 & -10.112325 & -1.6 \\
\hline $\mathrm{Ag}$ & -13.132014 & -4.667425 & 0009 \\
\hline & 10.608116 & 9.038945 & 0.240009 \\
\hline A & -13.132014 & 4.667425 & 009 \\
\hline$g$ & 2.523898 & 13.706371 & 0.240009 \\
\hline $\mathrm{Ag}$ & 10.608116 & -9.038945 & 0.240009 \\
\hline $\mathrm{Ag}$ & 2.523898 & -13.706371 & 0.240009 \\
\hline $\mathrm{Ag}$ & -13.079773 & -1.593239 & 0.297832 \\
\hline 118 & 7.919671 & 10.530796 & 0.297832 \\
\hline 18 & -13.079773 & 1.593239 & 0.297832 \\
\hline $\mathrm{Ag}$ & 5.160101 & 12.124035 & 0.297832 \\
\hline
\end{tabular}




\begin{tabular}{|c|c|c|c|}
\hline $\operatorname{Ag}$ & 7.919671 & -10.530796 & 0.297832 \\
\hline $\mathrm{Ag}$ & 5.160101 & -12.124035 & 0297832 \\
\hline g & -0.094487 & 15.172654 & 0.487307 \\
\hline g & -13.092660 & 7.668155 & 0.487307 \\
\hline g & -0.094487 & -15.172654 & 0.487307 \\
\hline $\mathrm{lg}$ & 13.187147 & -7.504499 & 0.487307 \\
\hline$g$ & -13.092660 & -7.668155 & 0.487307 \\
\hline g & 13.187147 & 7.504499 & 0.487307 \\
\hline$g$ & -5.417787 & 12.383932 & 0.676159 \\
\hline g & -8.015906 & 10.883907 & 0.676159 \\
\hline g & -5.417787 & -12.383932 & \\
\hline g & 13.433693 & -1.500025 & 0.676159 \\
\hline$g$ & -8.015906 & -10.883907 & \\
\hline$g$ & 13.433693 & 1.500025 & 0.67 \\
\hline$g$ & -2.810427 & 13.837082 & 460 \\
\hline Ag & -10.578051 & 9.352442 & 460 \\
\hline $\mathrm{Ag}$ & -2.810427 & -13.837082 & \\
\hline $\mathrm{g}$ & 13.388478 & -4.484640 & 160 \\
\hline $\mathrm{g}$ & -10.578051 & -9.352442 & 0.730460 \\
\hline $\mathrm{Ag}$ & 13.388478 & 4.484640 & 0.730460 \\
\hline g & 0.000000 & 0.000000 & 1.023508 \\
\hline Ag & -0.005871 & 3.057964 & 958 \\
\hline Ag & -2.645339 & 1.534066 & 1.132958 \\
\hline $\mathrm{Ag}$ & -0.005871 & -3.057964 & 1.132958 \\
\hline Ag & 2.651209 & -1.523898 & 1.132958 \\
\hline $\mathrm{Ag}$ & -2.645339 & -1.534066 & 1.132958 \\
\hline $\mathrm{Ag}$ & 2.651209 & 1.523898 & 958 \\
\hline $\mathrm{Ag}$ & -5.257672 & 0.000000 & 300 \\
\hline $\mathrm{Ag}$ & 2.628836 & 4.553278 & 3300 \\
\hline $\mathrm{Ag}$ & 2.628836 & -4.553278 & 8300 \\
\hline $\mathrm{Ag}$ & -2.672926 & 7.669849 & 4878 \\
\hline $\mathrm{Ag}$ & -5.305821 & 6.149747 & 1.194878 \\
\hline $\mathrm{Ag}$ & -2.672926 & -7.669849 & 1.194878 \\
\hline $\mathrm{Ag}$ & 7.978747 & -1.520102 & 1.194878 \\
\hline $\mathrm{Ag}$ & -5.305821 & -6.149747 & 1.194878 \\
\hline $\mathrm{Ag}$ & 7.978747 & 1.520102 & 1.194878 \\
\hline $\mathrm{Ag}$ & -0.036086 & 6.128158 & 1.203431 \\
\hline $\mathrm{Ag}$ & -5.289098 & 3.095331 & 1.203431 \\
\hline $\mathrm{Ag}$ & -0.036086 & -6.128158 & 1.203431 \\
\hline $\mathrm{Ag}$ & 5.325184 & -3.032828 & 1.203431 \\
\hline $\mathrm{Ag}$ & -5.289098 & -3.095331 & 1.203431 \\
\hline $\mathrm{Ag}$ & 5.325184 & 3.032828 & 1.203431 \\
\hline $\mathrm{Ag}$ & -10.482963 & 0.000000 & 1.198702 \\
\hline $\mathrm{Ag}$ & 5.241482 & 9.078512 & 1.198702 \\
\hline $\mathrm{Ag}$ & 5.241482 & -9.078512 & 1.198702 \\
\hline $\mathrm{Ag}$ & -5.312810 & 9.202056 & 1.192267 \\
\hline $\mathrm{Ag}$ & -5.312810 & -9.202056 & 1.192267 \\
\hline $\mathrm{Ag}$ & 10.625619 & 0.000000 & 1.192267 \\
\hline $\mathrm{Ag}$ & -2.650993 & 4.591655 & 1.212813 \\
\hline
\end{tabular}

$\begin{array}{lccc}\mathrm{Ag} & -2.650993 & -4.591655 & 1.212813 \\ \mathrm{Ag} & 5.301987 & 0.000000 & 1.212813 \\ \mathrm{Ag} & -0.044086 & 9.174546 & 1.224618 \\ \mathrm{Ag} & -7.923347 & 4.625453 & 1.224618 \\ \mathrm{Ag} & -0.044086 & -9.174546 & 1.224618 \\ \mathrm{Ag} & 7.967433 & -4.549093 & 1.224618 \\ \mathrm{Ag} & -7.923347 & -4.625453 & 1.224618 \\ \mathrm{Ag} & 7.967433 & 4.549093 & 1.224618 \\ \mathrm{Ag} & -7.889211 & -1.551838 & 1.235125 \\ \mathrm{Ag} & 5.288537 & 6.056339 & 1.235125 \\ \mathrm{Ag} & -7.889211 & 1.551838 & 1.235125 \\ \mathrm{Ag} & 2.600675 & 7.608176 & 1.235125 \\ \mathrm{Ag} & 5.288537 & -6.056339 & 1.235125 \\ \mathrm{Ag} & 2.600675 & -7.608176 & 1.235125 \\ \mathrm{Ag} & -10.508123 & -3.094728 & 1.242239 \\ \mathrm{Ag} & 7.934175 & 7.552937 & 1.242239 \\ \mathrm{Ag} & -10.508123 & 3.094728 & 1.242239 \\ \mathrm{Ag} & 2.573948 & 10.647666 & 1.242239 \\ \mathrm{Ag} & 7.934175 & -7.552937 & 1.242239 \\ \mathrm{Ag} & 2.573948 & -10.647666 & 1.242239 \\ \mathrm{Ag} & -2.692265 & 10.736687 & 1.239069 \\ \mathrm{Ag} & -7.952111 & 7.699913 & 1.239069 \\ \mathrm{Ag} & -2.692265 & -10.736687 & 1.239069 \\ \mathrm{Ag} & 10.644376 & -3.036774 & 1.239069 \\ \mathrm{Ag} & -7.952111 & -7.699913 & 1.239069 \\ \mathrm{Ag} & 10.644376 & 3.036774 & 1.239069 \\ \mathrm{Ag} & -0.070019 & 12.182003 & 1.297401 \\ \mathrm{Ag} & -10.514915 & 6.151640 & 1.297401 \\ \mathrm{Ag} & -0.070019 & -12.182003 & 1.297401 \\ \mathrm{Ag} & 10.584933 & -6.030363 & 1.297401 \\ \mathrm{Ag} & -10.514915 & -6.151640 & 1.297401 \\ \mathrm{Ag} & 10.584933 & 6.030363 \\ \mathrm{C} & 0.000033 & 1.404795 & 4.281678 \\ \mathrm{C} & -1.216604 & 0.702369 & 4.281678 \\ \mathrm{C} & -1.216604 & -0.702369 & 4.281678 \\ \mathrm{C} & 0.000033 & -1.404795 & 4.281678 \\ \mathrm{C} & 1.216572 & -0.702426 & 4.281678 \\ \mathrm{C} & 1.216572 & 0.702426 & 4.281678 \\ \mathrm{H} & 0.000240 & 2.497448 & 4.272639 \\ \mathrm{H} & -2.162974 & 1.248516 & 4.272639 \\ \mathrm{H} & -2.162974 & -1.248516 & 4.272639 \\ & 0.000240 & -2.497448 & 4.272639 \\ & 2.162734 & -1.248932 & 4.272639 \\ \mathrm{Ag} & 1.248932 & 4.272639\end{array}$

S5- Cu(111) 64-Benzene

$\mathrm{E}=-232.05207362$ eV Symmetry: $\mathrm{C}_{3 \mathrm{v}}$ $\begin{array}{lrrr}\text { CU } & -5.158257 & -3.828868 & 2.032641 \\ \text { CU } & -5.158257 & 3.828868 & 2.032641\end{array}$ 


\begin{tabular}{|c|c|c|c|c|c|c|c|}
\hline $\mathrm{CU}$ & -0.736769 & 6.381616 & 2.032641 & $\mathrm{CU}$ & 2.227987 & 1.291122 & -0.179093 \\
\hline $\mathrm{CU}$ & -0.736769 & -6.381616 & 2.032641 & $\mathrm{CU}$ & 2.221518 & -3.847783 & -0.224244 \\
\hline $\mathrm{CU}$ & 5.895026 & -2.552748 & 2.032641 & $\mathrm{CU}$ & -4.443037 & 0.000000 & -0.224244 \\
\hline $\mathrm{CU}$ & 5.895026 & 2.552748 & 2.032641 & $\mathrm{CU}$ & 2.221518 & 3.847783 & -0.224244 \\
\hline $\mathrm{CU}$ & -0.736889 & -1.276329 & 2.032520 & $\mathrm{CU}$ & 0.015427 & -5.110435 & -0.228404 \\
\hline $\mathrm{CU}$ & -0.736889 & 1.276329 & 2.032520 & $\mathrm{CU}$ & -4.433480 & -2.541858 & -0.228404 \\
\hline $\mathrm{CU}$ & 1.473778 & 0.000000 & 2.032520 & $\mathrm{CU}$ & -4.433480 & 2.541858 & -0.228404 \\
\hline $\mathrm{CU}$ & -2.947539 & 5.105288 & 2.032512 & $\mathrm{CU}$ & 0.015427 & 5.110435 & -0.228404 \\
\hline $\mathrm{CU}$ & -2.947539 & -5.105288 & 2.032512 & $\mathrm{CU}$ & 4.418053 & 2.568577 & -0.228404 \\
\hline $\mathrm{CU}$ & 5.895078 & 0.000000 & 2.032512 & $\mathrm{CU}$ & 4.418053 & -2.568577 & -0.228404 \\
\hline $\mathrm{CU}$ & -2.947628 & 0.000000 & 2.032371 & $\mathrm{CU}$ & -2.210259 & -3.828281 & -0.251616 \\
\hline $\mathrm{CU}$ & 1.473814 & 2.552721 & 2.032371 & $\mathrm{CU}$ & -2.210259 & 3.828281 & -0.251616 \\
\hline $\mathrm{CU}$ & 1.473814 & -2.552721 & 2.032371 & $\mathrm{CU}$ & 4.420518 & 0.000000 & -0.251616 \\
\hline $\mathrm{CU}$ & -2.947628 & 2.552669 & 2.032312 & $\mathrm{C}$ & -1.219381 & 0.704528 & -3.012385 \\
\hline $\mathrm{CU}$ & -2.947628 & -2.552669 & 2.032312 & $\mathrm{C}$ & -1.219381 & -0.704528 & -3.012385 \\
\hline $\mathrm{CU}$ & -0.736862 & 3.829055 & 2.032312 & $\mathrm{C}$ & -0.000449 & -1.408279 & -3.012385 \\
\hline $\mathrm{CU}$ & 3.684490 & 1.276386 & 2.032312 & $\mathrm{C}$ & 1.219830 & -0.703750 & -3.012385 \\
\hline $\mathrm{CU}$ & 3.684490 & -1.276386 & 2.032312 & $\mathrm{C}$ & 1.219830 & 0.703750 & -3.012385 \\
\hline $\mathrm{CU}$ & -0.736862 & -3.829055 & 2.032312 & $\mathrm{C}$ & -0.000449 & 1.408279 & -3.012385 \\
\hline $\mathrm{CU}$ & -5.158207 & -1.276329 & 2.032302 & $\mathrm{H}$ & -2.166704 & 1.250391 & -2.989851 \\
\hline $\mathrm{CU}$ & -5.158207 & 1.276329 & 2.032302 & $\mathrm{H}$ & -2.166704 & -1.250391 & -2.989851 \\
\hline $\mathrm{CU}$ & 1.473770 & 5.105303 & 2.032302 & $\mathrm{H}$ & 0.000482 & -2.501616 & -2.989851 \\
\hline $\mathrm{CU}$ & 3.684437 & 3.828974 & 2.032302 & $\mathrm{H}$ & 2.166222 & -1.251226 & -2.989851 \\
\hline $\mathrm{CU}$ & 1.473770 & -5.105303 & 2.032302 & $\mathrm{H}$ & 2.166222 & 1.251226 & -2.989851 \\
\hline $\mathrm{CU}$ & 3.684437 & -3.828974 & 2.032302 & $\mathrm{H}$ & 0.000482 & 2.501616 & -2.989851 \\
\hline $\mathrm{CU}$ & 4.438931 & -5.160010 & 0.025258 & & & & \\
\hline $\mathrm{CU}$ & 2.249234 & -6.424232 & 0.025258 & \multicolumn{4}{|c|}{ S6-Cu(111)-TPP } \\
\hline $\mathrm{CU}$ & -6.688165 & -1.264222 & 0.025258 & \multicolumn{4}{|c|}{$E=-957.51619907 \mathrm{eV}$ Symmetry: $C_{s}$} \\
\hline $\mathrm{CU}$ & -6.688165 & 1.264222 & 0.025258 & $\mathrm{Cu}$ & 8.105765 & -1.142575 & -6.381640 \\
\hline $\mathrm{CU}$ & 2.249234 & 6.424232 & 0.025258 & $\mathrm{Cu}$ & 8.105765 & -1.142575 & 6.381640 \\
\hline $\mathrm{CU}$ & 4.438931 & 5.160010 & 0.025258 & $\mathrm{Cu}$ & 1.473780 & -1.142575 & -10.210618 \\
\hline $\mathrm{CU}$ & 6.603256 & -3.830932 & -0.073919 & $\mathrm{Cu}$ & 1.473780 & -1.142575 & 10.210618 \\
\hline $\mathrm{CU}$ & 0.016057 & -7.634053 & -0.073919 & $\mathrm{Cu}$ & -9.579545 & -1.142575 & 3.828978 \\
\hline $\mathrm{CU}$ & -6.619312 & -3.803121 & -0.073919 & $\mathrm{Cu}$ & -9.579545 & -1.142575 & -3.828978 \\
\hline $\mathrm{CU}$ & -6.619312 & 3.803121 & -0.073919 & $\mathrm{Cu}$ & 5.895106 & -1.142573 & -7.657965 \\
\hline $\mathrm{CU}$ & 0.016057 & 7.634053 & -0.073919 & $\mathrm{Cu}$ & 5.895106 & -1.142573 & 7.657965 \\
\hline $\mathrm{CU}$ & 6.603256 & 3.830932 & -0.073919 & $\mathrm{Cu}$ & 3.684439 & -1.142573 & -8.934294 \\
\hline $\mathrm{CU}$ & 6.639379 & 1.270970 & -0.116967 & $\mathrm{Cu}$ & 3.684439 & -1.142573 & 8.934294 \\
\hline $\mathrm{CU}$ & 6.639379 & -1.270970 & -0.116967 & $\mathrm{Cu}$ & -9.579545 & -1.142573 & 1.276329 \\
\hline $\mathrm{CU}$ & -2.218997 & -6.385356 & -0.116967 & $\mathrm{Cu}$ & -9.579545 & -1.142573 & -1.276329 \\
\hline $\mathrm{CU}$ & -4.420382 & -5.114386 & -0.116967 & $\mathrm{Cu}$ & 5.895105 & -1.142571 & -5.105304 \\
\hline $\mathrm{CU}$ & -4.420382 & 5.114386 & -0.116967 & $\mathrm{Cu}$ & 5.895105 & -1.142571 & 5.105304 \\
\hline $\mathrm{CU}$ & -2.218997 & 6.385356 & -0.116967 & $\mathrm{Cu}$ & 1.473770 & -1.142571 & -7.657963 \\
\hline $\mathrm{CU}$ & 0.000000 & 0.000000 & -0.079687 & $\mathrm{Cu}$ & 1.473770 & -1.142571 & 7.657963 \\
\hline $\mathrm{CU}$ & 2.227987 & -1.291122 & -0.179093 & $\mathrm{Cu}$ & -7.368876 & -1.142571 & 2.552659 \\
\hline $\mathrm{CU}$ & 0.004151 & -2.575054 & -0.179093 & $\mathrm{Cu}$ & -7.368876 & -1.142571 & -2.552659 \\
\hline $\mathrm{CU}$ & -2.232138 & -1.283932 & -0.179093 & $\mathrm{Cu}$ & 10.316433 & -1.142569 & 5.105310 \\
\hline $\mathrm{CU}$ & -2.232138 & 1.283932 & -0.179093 & $\mathrm{Cu}$ & 10.316433 & -1.142569 & -5.105310 \\
\hline $\mathrm{CU}$ & 0.004151 & 2.575054 & -0.179093 & $\mathrm{Cu}$ & 3.684438 & -1.142569 & -6.381633 \\
\hline
\end{tabular}




\begin{tabular}{|c|c|c|c|}
\hline $\mathrm{Cu}$ & 3.684438 & -1.142569 & 6.381633 \\
\hline $\mathrm{Cu}$ & -0.736888 & -1.142569 & -11.486948 \\
\hline $\mathrm{Cu}$ & -0.736888 & -1.142569 & 11.486948 \\
\hline $\mathrm{Cu}$ & -7.368876 & -1.142569 & 0.000000 \\
\hline $\mathrm{Cu}$ & -9.579545 & -1.142569 & -6.381638 \\
\hline $\mathrm{Cu}$ & -9.579545 & -1.142569 & 6.381638 \\
\hline $\mathrm{Cu}$ & 3.684442 & -1.142567 & -3.828982 \\
\hline $\mathrm{Cu}$ & 3.684442 & -1.142567 & 3.828982 \\
\hline $\mathrm{Cu}$ & 1.473774 & -1.142567 & -5.105311 \\
\hline $\mathrm{Cu}$ & 1.473774 & -1.142567 & 5.105311 \\
\hline $\mathrm{Cu}$ & -5.158216 & -1.142567 & 1.276329 \\
\hline $\mathrm{Cu}$ & -5.158216 & -1.142567 & -1.276329 \\
\hline $\mathrm{Cu}$ & 8.105764 & -1.142566 & 3.828979 \\
\hline $\mathrm{Cu}$ & 8.105764 & -1.142566 & -3.828979 \\
\hline $\mathrm{Cu}$ & -0.736889 & -1.142566 & -8.934287 \\
\hline $\mathrm{Cu}$ & -0.736889 & -1.142566 & 8.934287 \\
\hline $\mathrm{Cu}$ & -7.368875 & -1.142566 & -5.105308 \\
\hline $\mathrm{Cu}$ & -7.368875 & -1.142566 & 5.105308 \\
\hline $\mathrm{Cu}$ & 10.316432 & -1.142565 & 2.552650 \\
\hline $\mathrm{Cu}$ & 10.316432 & -1.142565 & -2.552650 \\
\hline $\mathrm{Cu}$ & -2.947556 & -1.142565 & -10.210617 \\
\hline $\mathrm{Cu}$ & -2.947556 & -1.142565 & 10.210617 \\
\hline $\mathrm{Cu}$ & -7.368876 & -1.142565 & -7.657967 \\
\hline $\mathrm{Cu}$ & -7.368876 & -1.142565 & 7.657967 \\
\hline $\mathrm{Cu}$ & 5.895101 & -1.142564 & -2.552657 \\
\hline $\mathrm{Cu}$ & 5.895101 & -1.142564 & 2.552657 \\
\hline $\mathrm{Cu}$ & -0.736884 & -1.142564 & -6.381636 \\
\hline $\mathrm{Cu}$ & -0.736884 & -1.142564 & 6.381636 \\
\hline $\mathrm{Cu}$ & -5.158216 & -1.142564 & -3.828978 \\
\hline $\mathrm{Cu}$ & -5.158216 & -1.142564 & 3.828978 \\
\hline $\mathrm{Cu}$ & 8.105768 & -1.142563 & -1.276328 \\
\hline $\mathrm{Cu}$ & 8.105768 & -1.142563 & 1.276328 \\
\hline $\mathrm{Cu}$ & 1.473774 & -1.142563 & -2.552651 \\
\hline $\mathrm{Cu}$ & 1.473774 & -1.142563 & 2.552651 \\
\hline $\mathrm{Cu}$ & -2.947547 & -1.142563 & 0.000000 \\
\hline $\mathrm{Cu}$ & -2.947552 & -1.142563 & -7.657965 \\
\hline $\mathrm{Cu}$ & -2.947552 & -1.142563 & 7.657965 \\
\hline $\mathrm{Cu}$ & -5.158216 & -1.142563 & -6.381637 \\
\hline $\mathrm{Cu}$ & -5.158216 & -1.142563 & 6.381637 \\
\hline $\mathrm{Cu}$ & 3.684441 & -1.142562 & -1.276321 \\
\hline $\mathrm{Cu}$ & 3.684441 & -1.142562 & 1.276321 \\
\hline $\mathrm{Cu}$ & -0.736894 & -1.142562 & -3.828980 \\
\hline $\mathrm{Cu}$ & -0.736894 & -1.142562 & 3.828980 \\
\hline $\mathrm{Cu}$ & -2.947547 & -1.142562 & -2.552659 \\
\hline $\mathrm{Cu}$ & -2.947547 & -1.142562 & 2.552659 \\
\hline $\mathrm{Cu}$ & 10.316427 & -1.142561 & 0.000000 \\
\hline $\mathrm{Cu}$ & -5.158214 & -1.142561 & -8.934288 \\
\hline $\mathrm{Cu}$ & -5.158214 & -1.142561 & 8.934288 \\
\hline $\mathrm{Cu}$ & 5.895100 & -1.142560 & 0.000000 \\
\hline
\end{tabular}

\begin{tabular}{|c|c|c|c|}
\hline $\mathrm{Cu}$ & 1.473778 & -1.142560 & 0.000000 \\
\hline $\mathrm{Cu}$ & -0.736889 & -1.142560 & -1.276329 \\
\hline $\mathrm{Cu}$ & -0.736889 & -1.142560 & 1.276329 \\
\hline $\mathrm{Cu}$ & -2.947550 & -1.142560 & -5.105306 \\
\hline $\mathrm{Cu}$ & -2.947550 & -1.142560 & 5.105306 \\
\hline $\mathrm{Cu}$ & 8.860490 & 0.957321 & -7.663791 \\
\hline $\mathrm{Cu}$ & 8.860490 & 0.957321 & 7.663791 \\
\hline $\mathrm{Cu}$ & 2.206793 & 0.957321 & -11.505305 \\
\hline $\mathrm{Cu}$ & 2.206793 & 0.957321 & 11.505305 \\
\hline $\mathrm{Cu}$ & -11.067282 & 0.957321 & 3.841514 \\
\hline $\mathrm{Cu}$ & -11.067282 & 0.957321 & -3.841514 \\
\hline $\mathrm{Cu}$ & 6.643155 & 0.943229 & -8.937935 \\
\hline $\mathrm{Cu}$ & 6.643155 & 0.943229 & 8.937935 \\
\hline $\mathrm{Cu}$ & 4.418901 & 0.943229 & -10.222109 \\
\hline $\mathrm{Cu}$ & 4.418901 & 0.943229 & 10.222109 \\
\hline $\mathrm{Cu}$ & -11.062056 & 0.943229 & 1.284174 \\
\hline $\mathrm{Cu}$ & -11.062056 & 0.943229 & -1.284174 \\
\hline $\mathrm{Cu}$ & 6.643226 & 1.063727 & -6.378226 \\
\hline $\mathrm{Cu}$ & 6.643226 & 1.063727 & 6.378226 \\
\hline $\mathrm{Cu}$ & 2.202092 & 1.063727 & -8.942316 \\
\hline $\mathrm{Cu}$ & 2.202092 & 1.063727 & 8.942316 \\
\hline $\mathrm{Cu}$ & -8.845319 & 1.063727 & 2.564090 \\
\hline $\mathrm{Cu}$ & -8.845319 & 1.063727 & -2.564090 \\
\hline $\mathrm{Cu}$ & 11.063551 & 0.959830 & 6.377028 \\
\hline $\mathrm{Cu}$ & 11.063551 & 0.959830 & -6.377028 \\
\hline $\mathrm{Cu}$ & 4.422871 & 1.063741 & -7.660638 \\
\hline $\mathrm{Cu}$ & 4.422871 & 1.063741 & 7.660638 \\
\hline $\mathrm{Cu}$ & -0.009107 & 0.959830 & -12.769830 \\
\hline $\mathrm{Cu}$ & -0.009107 & 0.959830 & 12.769830 \\
\hline $\mathrm{Cu}$ & -8.845743 & 1.063741 & 0.000000 \\
\hline $\mathrm{Cu}$ & -11.054444 & 0.959830 & -6.392802 \\
\hline $\mathrm{Cu}$ & -11.054444 & 0.959830 & 6.392802 \\
\hline $\mathrm{Cu}$ & 4.424540 & 1.100325 & -5.101812 \\
\hline $\mathrm{Cu}$ & 4.424540 & 1.100325 & 5.101812 \\
\hline $\mathrm{Cu}$ & 2.206028 & 1.100325 & -6.382670 \\
\hline $\mathrm{Cu}$ & 2.206028 & 1.100325 & 6.382670 \\
\hline $\mathrm{Cu}$ & -6.630569 & 1.100325 & 1.280858 \\
\hline $\mathrm{Cu}$ & -6.630569 & 1.100325 & -1.280858 \\
\hline $\mathrm{Cu}$ & 8.866523 & 1.085428 & 5.105915 \\
\hline $\mathrm{Cu}$ & 8.866523 & 1.085428 & -5.105915 \\
\hline $\mathrm{Cu}$ & -0.011409 & 1.085428 & -10.231592 \\
\hline $\mathrm{Cu}$ & -0.011409 & 1.085428 & 10.231592 \\
\hline $\mathrm{Cu}$ & -8.855114 & 1.085428 & -5.125676 \\
\hline $\mathrm{Cu}$ & -8.855114 & 1.085428 & 5.125676 \\
\hline $\mathrm{Cu}$ & 11.105078 & 0.976411 & 3.825237 \\
\hline $\mathrm{Cu}$ & 11.105078 & 0.976411 & -3.825237 \\
\hline $\mathrm{Cu}$ & -2.239787 & 0.976411 & -11.529898 \\
\hline $\mathrm{Cu}$ & -2.239787 & 0.976411 & 11.529898 \\
\hline $\mathrm{Cu}$ & -8.865291 & 0.976411 & -7.704661 \\
\hline
\end{tabular}




\begin{tabular}{|c|c|c|c|c|c|c|c|}
\hline $\mathrm{Cu}$ & -8.865291 & 0.976411 & 7.704661 & $\mathrm{H}$ & 2.413003 & 3.428917 & -5.054629 \\
\hline $\mathrm{Cu}$ & 6.648332 & 1.090726 & 3.830177 & $\mathrm{H}$ & 2.413003 & 3.428917 & 5.054629 \\
\hline $\mathrm{Cu}$ & 6.648332 & 1.090726 & -3.830177 & $\mathrm{H}$ & -3.680270 & 3.527812 & -6.874598 \\
\hline $\mathrm{Cu}$ & -0.007135 & 1.090726 & -7.672713 & $\mathrm{H}$ & -3.680270 & 3.527812 & 6.874598 \\
\hline $\mathrm{Cu}$ & -0.007135 & 1.090726 & 7.672713 & $\mathrm{H}$ & 4.080223 & 3.547983 & -6.859862 \\
\hline $\mathrm{Cu}$ & -6.641197 & 1.090726 & -3.842536 & $\mathrm{H}$ & 4.080223 & 3.547983 & 6.859862 \\
\hline $\mathrm{Cu}$ & -6.641197 & 1.090726 & 3.842536 & $\mathrm{H}$ & 5.263510 & 3.498115 & 1.334079 \\
\hline $\mathrm{Cu}$ & 2.209076 & 1.069521 & -3.826233 & $\mathrm{H}$ & 5.263510 & 3.498115 & -1.334079 \\
\hline $\mathrm{Cu}$ & 2.209076 & 1.069521 & 3.826233 & $\mathrm{H}$ & -4.937082 & 3.505484 & -1.330024 \\
\hline $\mathrm{Cu}$ & -4.418153 & 1.069521 & 0.000000 & $\mathrm{H}$ & -4.937082 & 3.505484 & 1.330024 \\
\hline $\mathrm{Cu}$ & 8.862277 & 1.105460 & 2.561247 & $\mathrm{C}$ & 4.410758 & 3.693234 & -0.694118 \\
\hline $\mathrm{Cu}$ & 8.862277 & 1.105460 & -2.561247 & $\mathrm{C}$ & 4.410758 & 3.693234 & 0.694118 \\
\hline $\mathrm{Cu}$ & 4.441194 & 1.098855 & -2.560546 & $\mathrm{C}$ & -4.082799 & 3.707161 & -0.693617 \\
\hline $\mathrm{Cu}$ & 4.441194 & 1.098855 & 2.560546 & $\mathrm{C}$ & -4.082799 & 3.707161 & 0.693617 \\
\hline $\mathrm{Cu}$ & -0.003099 & 1.098855 & -5.126460 & $\mathrm{C}$ & -3.018739 & 3.870888 & -4.853508 \\
\hline $\mathrm{Cu}$ & -0.003099 & 1.098855 & 5.126460 & $\mathrm{C}$ & -3.018739 & 3.870888 & 4.853508 \\
\hline $\mathrm{Cu}$ & -2.213034 & 1.105460 & -8.955581 & $\mathrm{C}$ & 3.390045 & 3.872533 & -4.847142 \\
\hline $\mathrm{Cu}$ & -2.213034 & 1.105460 & 8.955581 & $\mathrm{C}$ & 3.390045 & 3.872533 & 4.847142 \\
\hline $\mathrm{Cu}$ & -4.438095 & 1.098855 & -2.565914 & $\mathrm{C}$ & -3.960609 & 3.914886 & -5.891039 \\
\hline $\mathrm{Cu}$ & -4.438095 & 1.098855 & 2.565914 & $\mathrm{C}$ & -3.960609 & 3.914886 & 5.891039 \\
\hline $\mathrm{Cu}$ & -6.649244 & 1.105460 & -6.394334 & $\mathrm{C}$ & 4.343340 & 3.934985 & -5.872117 \\
\hline $\mathrm{Cu}$ & -6.649244 & 1.105460 & 6.394334 & $\mathrm{C}$ & 4.343340 & 3.934985 & 5.872117 \\
\hline $\mathrm{Cu}$ & 11.094578 & 0.983895 & $5 \quad 1.281284$ & $\mathrm{C}$ & 3.077207 & 3.996465 & 1.146630 \\
\hline $\mathrm{Cu}$ & 11.094578 & 0.983895 & $5-1.281284$ & $\mathrm{C}$ & 3.077207 & 3.996465 & -1.146630 \\
\hline $\mathrm{Cu}$ & -4.437664 & 0.983895 & -10.248829 & $\mathrm{C}$ & -2.748589 & 4.004284 & -1.147257 \\
\hline $\mathrm{Cu}$ & -4.437664 & 0.983895 & 10.248829 & $\mathrm{C}$ & -2.748589 & 4.004284 & 1.147257 \\
\hline $\mathrm{Cu}$ & -6.656914 & 0.983895 & -8.967544 & $\mathrm{~N}$ & 0.168513 & 4.113168 & -2.054745 \\
\hline $\mathrm{Cu}$ & -6.656914 & 0.983895 & 8.967544 & $\mathrm{~N}$ & 0.168513 & 4.113168 & 2.054745 \\
\hline $\mathrm{Cu}$ & 6.644651 & 1.081595 & -1.271261 & $\mathrm{~N}$ & 2.305394 & 4.111571 & 0.000000 \\
\hline $\mathrm{Cu}$ & 6.644651 & 1.081595 & 1.271261 & $\mathrm{~N}$ & -1.976669 & 4.117776 & 0.000000 \\
\hline $\mathrm{Cu}$ & -2.221381 & 1.081595 & -6.390067 & $\mathrm{C}$ & 2.635935 & 4.264059 & -2.471391 \\
\hline $\mathrm{Cu}$ & -2.221381 & 1.081595 & 6.390067 & $\mathrm{C}$ & 2.635935 & 4.264059 & 2.471391 \\
\hline $\mathrm{Cu}$ & -4.423270 & 1.081595 & -5.118806 & $\mathrm{C}$ & -2.300769 & 4.271351 & -2.470363 \\
\hline $\mathrm{Cu}$ & -4.423270 & 1.081595 & 5.118806 & $\mathrm{C}$ & -2.300769 & 4.271351 & 2.470363 \\
\hline $\mathrm{Cu}$ & 8.870651 & 1.101197 & 0.000000 & $\mathrm{H}$ & 1.293361 & 4.231886 & 0.000000 \\
\hline $\mathrm{Cu}$ & 2.218557 & 1.061629 & -1.275808 & $\mathrm{H}$ & -0.966019 & 4.246815 & 0.000000 \\
\hline $\mathrm{Cu}$ & 2.218557 & 1.061629 & 1.275808 & $\mathrm{C}$ & 1.267815 & 4.487450 & -2.807675 \\
\hline $\mathrm{Cu}$ & -0.004397 & 1.061629 & -2.559231 & $\mathrm{C}$ & -0.931175 & 4.496396 & -2.802688 \\
\hline $\mathrm{Cu}$ & -0.004397 & 1.061629 & 2.559231 & $\mathrm{C}$ & 1.267815 & 4.487450 & 2.807675 \\
\hline $\mathrm{Cu}$ & -2.214160 & 1.061629 & -1.283423 & $\mathrm{C}$ & -0.931175 & 4.496396 & 2.802688 \\
\hline $\mathrm{Cu}$ & -2.214160 & 1.061629 & 1.283423 & $\mathrm{C}$ & -3.317766 & 4.364024 & -3.558318 \\
\hline $\mathrm{Cu}$ & -4.435326 & 1.101197 & -7.682209 & $\mathrm{C}$ & -3.317766 & 4.364024 & 3.558318 \\
\hline $\mathrm{Cu}$ & -4.435326 & 1.101197 & 7.682209 & $\mathrm{C}$ & 3.663740 & 4.370267 & -3.547697 \\
\hline $\mathrm{Cu}$ & 4.430122 & 1.090351 & 0.000000 & $\mathrm{C}$ & 3.663740 & 4.370267 & 3.547697 \\
\hline $\mathrm{Cu}$ & -2.215061 & 1.090351 & -3.836598 & $\mathrm{C}$ & -5.252599 & 4.409375 & -5.657177 \\
\hline $\mathrm{Cu}$ & -2.215061 & 1.090351 & 3.836598 & $\mathrm{C}$ & -5.252599 & 4.409375 & 5.657177 \\
\hline $\mathrm{Cu}$ & 0.000000 & 1.067131 & 0.000000 & $\mathrm{C}$ & 5.622124 & 4.455029 & -5.621083 \\
\hline $\mathrm{H}$ & -2.033407 & 3.439537 & -5.049510 & $\mathrm{C}$ & 5.622124 & 4.455029 & 5.621083 \\
\hline $\mathrm{H}$ & -2.033407 & 3.439537 & 5.049510 & $\mathrm{H}$ & -6.000074 & 4.395734 & -6.453389 \\
\hline
\end{tabular}




\begin{tabular}{|c|c|c|c|c|c|c|c|}
\hline $\mathrm{H}$ & -6.000074 & 4.395734 & 6.453389 & $\mathrm{Ag}$ & -3.336202 & -1.641274 & -2.889240 \\
\hline $\mathrm{H}$ & 6.378724 & 4.460467 & -6.408469 & $\mathrm{Ag}$ & -0.834054 & -1.641274 & -4.333856 \\
\hline $\mathrm{H}$ & 6.378724 & 4.460467 & 6.408469 & $\mathrm{Ag}$ & 9.174558 & -1.641273 & -1.444606 \\
\hline $\mathrm{C}$ & 0.850339 & 5.187219 & -4.018859 & $\mathrm{Ag}$ & -5.838345 & -1.641273 & 7.223097 \\
\hline $\mathrm{C}$ & -0.512709 & 5.196463 & -4.013708 & $\mathrm{Ag}$ & 9.174558 & -1.641273 & 1.444606 \\
\hline $\mathrm{C}$ & 0.850339 & 5.187219 & 4.018859 & $\mathrm{Ag}$ & -3.336213 & -1.641273 & 8.667703 \\
\hline $\mathrm{C}$ & -0.512709 & 5.196463 & 4.013708 & $\mathrm{Ag}$ & -5.838345 & -1.641273 & -7.223097 \\
\hline $\mathrm{C}$ & -4.599444 & 4.937818 & -3.370715 & $\mathrm{Ag}$ & -3.336213 & -1.641273 & -8.667703 \\
\hline $\mathrm{C}$ & -4.599444 & 4.937818 & 3.370715 & $\mathrm{Ag}$ & 6.672402 & -1.641271 & -2.889230 \\
\hline $\mathrm{C}$ & 4.932106 & 4.965769 & -3.342126 & $\mathrm{Ag}$ & -5.838348 & -1.641271 & 4.333854 \\
\hline $\mathrm{C}$ & 4.932106 & 4.965769 & 3.342126 & $\mathrm{Ag}$ & 6.672402 & -1.641271 & 2.889230 \\
\hline $\mathrm{C}$ & -5.559409 & 4.933243 & -4.391369 & $\mathrm{Ag}$ & -0.834054 & -1.641271 & 7.223084 \\
\hline $\mathrm{C}$ & -5.559409 & 4.933243 & 4.391369 & $\mathrm{Ag}$ & -5.838348 & -1.641271 & -4.333854 \\
\hline $\mathrm{C}$ & 5.904040 & 4.981769 & -4.351489 & $\mathrm{Ag}$ & -0.834054 & -1.641271 & -7.223084 \\
\hline $\mathrm{C}$ & 5.904040 & 4.981769 & 4.351489 & $\mathrm{Ag}$ & 11.676697 & -1.641269 & -2.889229 \\
\hline $\mathrm{H}$ & 1.510412 & 5.665262 & -4.735782 & $\mathrm{Ag}$ & -8.340494 & -1.641269 & 8.667702 \\
\hline $\mathrm{H}$ & -1.171185 & 5.684383 & -4.725353 & $\mathrm{Ag}$ & 11.676697 & -1.641269 & 2.889229 \\
\hline $\mathrm{H}$ & 1.510412 & 5.665262 & 4.735782 & $\mathrm{Ag}$ & -3.336203 & -1.641269 & 11.556930 \\
\hline $\mathrm{H}$ & -1.171185 & 5.684383 & 4.725353 & $\mathrm{Ag}$ & -8.340494 & -1.641269 & -8.667702 \\
\hline $\mathrm{H}$ & -4.837403 & 5.418834 & -2.422055 & $\mathrm{Ag}$ & -3.336203 & -1.641269 & -11.556930 \\
\hline $\mathrm{H}$ & -4.837403 & 5.418834 & 2.422055 & $\mathrm{Ag}$ & 6.672412 & -1.641266 & 0.000000 \\
\hline $\mathrm{H}$ & 5.149857 & 5.447322 & -2.388692 & $\mathrm{Ag}$ & -3.336206 & -1.641266 & 5.778479 \\
\hline $\mathrm{H}$ & 5.149857 & 5.447322 & 2.388692 & $\mathrm{Ag}$ & -3.336206 & -1.641266 & -5.778479 \\
\hline $\mathrm{H}$ & -6.545452 & 5.362555 & -4.201567 & $\mathrm{Ag}$ & 11.676702 & -1.641265 & 0.000000 \\
\hline $\mathrm{H}$ & -6.545452 & 5.362555 & 4.201567 & $\mathrm{Ag}$ & -5.838351 & -1.641265 & 10.112321 \\
\hline $\mathrm{H}$ & 6.879476 & 5.428928 & -4.149203 & $\mathrm{Ag}$ & -5.838351 & -1.641265 & -10.112321 \\
\hline \multirow[t]{2}{*}{$\mathrm{H}$} & 6.879476 & 5.428928 & 4.149203 & $\mathrm{Ag}$ & 1.668100 & -1.641263 & 2.889235 \\
\hline & & & & $\mathrm{Ag}$ & 1.668100 & -1.641263 & -2.889235 \\
\hline \multicolumn{4}{|c|}{$\underline{\text { S7- Ag(111)-TPP }}$} & $\mathrm{Ag}$ & -3.336201 & -1.641263 & 0.000000 \\
\hline \multicolumn{3}{|c|}{$\mathrm{E}=-823.67750703 \mathrm{eV}$} & Symmetry: $\mathrm{C}_{\mathrm{s}}$ & $\mathrm{Ag}$ & 1.668103 & -1.641259 & 5.778477 \\
\hline $\mathrm{Ag}$ & 1.668103 & -1.641278 & 0.000000 & $\mathrm{Ag}$ & 4.170256 & -1.641259 & 4.333858 \\
\hline $\mathrm{Ag}$ & -0.834052 & -1.641278 & 1.444620 & $\mathrm{Ag}$ & 1.668103 & -1.641259 & -5.778477 \\
\hline $\mathrm{Ag}$ & -0.834052 & -1.641278 & -1.444620 & $\mathrm{Ag}$ & -5.838359 & -1.641259 & -1.444619 \\
\hline $\mathrm{Ag}$ & 9.174555 & -1.641277 & -4.333848 & $\mathrm{Ag}$ & 4.170256 & -1.641259 & -4.333858 \\
\hline $\mathrm{Ag}$ & -8.340500 & -1.641277 & 5.778474 & $\mathrm{Ag}$ & -5.838359 & -1.641259 & 1.444619 \\
\hline $\mathrm{Ag}$ & 9.174555 & -1.641277 & 4.333848 & $\mathrm{Ag}$ & 1.668099 & -1.641254 & 8.667711 \\
\hline $\mathrm{Ag}$ & -0.834055 & -1.641277 & 10.112322 & $\mathrm{Ag}$ & 6.672408 & -1.641254 & 5.778472 \\
\hline $\mathrm{Ag}$ & -8.340500 & -1.641277 & -5.778474 & $\mathrm{Ag}$ & 1.668099 & -1.641254 & -8.667711 \\
\hline $\mathrm{Ag}$ & -0.834055 & -1.641277 & -10.112322 & $\mathrm{Ag}$ & -8.340507 & -1.641254 & -2.889239 \\
\hline $\mathrm{Ag}$ & 11.676708 & -1.641274 & -5.778467 & $\mathrm{Ag}$ & 6.672408 & -1.641254 & -5.778472 \\
\hline $\mathrm{Ag}$ & -10.842654 & -1.641274 & $4 \quad 7.223092$ & $\mathrm{Ag}$ & -8.340507 & -1.641254 & 2.889239 \\
\hline $\mathrm{Ag}$ & 11.676708 & -1.641274 & 5.778467 & $\mathrm{Ag}$ & 4.170254 & -1.641251 & 7.223091 \\
\hline $\mathrm{Ag}$ & -0.834054 & -1.641274 & 13.001559 & $\mathrm{Ag}$ & 4.170254 & -1.641251 & -7.223091 \\
\hline $\mathrm{Ag}$ & -10.842654 & -1.641274 & $4 \quad-7.223092$ & $\mathrm{Ag}$ & -8.340507 & -1.641251 & 0.000000 \\
\hline $\mathrm{Ag}$ & -0.834054 & -1.641274 & -13.001559 & $\mathrm{Ag}$ & 1.668105 & -1.641250 & 11.556939 \\
\hline $\mathrm{Ag}$ & 4.170256 & -1.641274 & -1.444616 & $\mathrm{Ag}$ & 9.174550 & -1.641250 & 7.223091 \\
\hline $\mathrm{Ag}$ & -3.336202 & -1.641274 & 2.889240 & $\mathrm{Ag}$ & 1.668105 & -1.641250 & -11.556939 \\
\hline $\mathrm{Ag}$ & 4.170256 & -1.641274 & 1.444616 & $\mathrm{Ag}$ & -10.842655 & -1.641250 & -4.333848 \\
\hline $\mathrm{Ag}$ & -0.834054 & -1.641274 & 4.333856 & $\mathrm{Ag}$ & 9.174550 & -1.641250 & -7.223091 \\
\hline
\end{tabular}




\begin{tabular}{|c|c|c|c|}
\hline $\mathrm{Ag}$ & -10.842655 & -1.641250 & 4.333848 \\
\hline $\mathrm{Ag}$ & 4.170250 & -1.641246 & 10.112325 \\
\hline $\mathrm{Ag}$ & 6.672406 & -1.641246 & 8.667705 \\
\hline $\mathrm{Ag}$ & 4.170250 & -1.641246 & -10.112325 \\
\hline $\mathrm{Ag}$ & -10.842656 & -1.641246 & -1.444620 \\
\hline $\mathrm{Ag}$ & 6.672406 & -1.641246 & -8.667705 \\
\hline $\mathrm{Ag}$ & -10.842656 & -1.641246 & 1.444620 \\
\hline $\mathrm{Ag}$ & 13.185879 & 0.422179 & -7.543353 \\
\hline $\mathrm{Ag}$ & -13.125675 & 0.422179 & 7.647630 \\
\hline $\mathrm{Ag}$ & 13.185879 & 0.422179 & 7.543353 \\
\hline $\mathrm{Ag}$ & -0.060204 & 0.422179 & 15.190983 \\
\hline $\mathrm{Ag}$ & -13.125675 & 0.422179 & -7.647630 \\
\hline $\mathrm{Ag}$ & -0.060204 & 0.422179 & -15.190983 \\
\hline $\mathrm{Ag}$ & 7.967890 & 1.220392 & -4.553228 \\
\hline $\mathrm{Ag}$ & -7.927156 & 1.220392 & 4.623781 \\
\hline $\mathrm{Ag}$ & 7.967890 & 1.220392 & 4.553228 \\
\hline $\mathrm{Ag}$ & -0.040734 & 1.220392 & 9.177009 \\
\hline $\mathrm{Ag}$ & -7.927156 & 1.220392 & -4.623781 \\
\hline $\mathrm{Ag}$ & -0.040734 & 1.220392 & -9.177009 \\
\hline $\mathrm{Ag}$ & 2.652585 & 1.109313 & -1.525809 \\
\hline $\mathrm{Ag}$ & -2.647682 & 1.109313 & 1.534302 \\
\hline $\mathrm{Ag}$ & 2.652585 & 1.109313 & 1.525809 \\
\hline $\mathrm{Ag}$ & -0.004903 & 1.109313 & 3.060111 \\
\hline $\mathrm{Ag}$ & -2.647682 & 1.109313 & -1.534302 \\
\hline $\mathrm{Ag}$ & -0.004903 & 1.109313 & -3.060111 \\
\hline $\mathrm{Ag}$ & 10.586752 & 1.278114 & -6.048115 \\
\hline $\mathrm{Ag}$ & -10.531197 & 1.278114 & 6.144339 \\
\hline $\mathrm{Ag}$ & 10.586752 & 1.278114 & 6.048115 \\
\hline $\mathrm{Ag}$ & -0.055555 & 1.278114 & 12.192454 \\
\hline $\mathrm{Ag}$ & -10.531197 & 1.278114 & -6.144339 \\
\hline $\mathrm{Ag}$ & -0.055555 & 1.278114 & -12.192454 \\
\hline $\mathrm{Ag}$ & 5.321744 & 1.213580 & -3.048868 \\
\hline $\mathrm{Ag}$ & -5.301269 & 1.213580 & 3.084331 \\
\hline $\mathrm{Ag}$ & 5.321744 & 1.213580 & 3.048868 \\
\hline $\mathrm{Ag}$ & -0.020475 & 1.213580 & 6.133199 \\
\hline $\mathrm{Ag}$ & -5.301269 & 1.213580 & -3.084331 \\
\hline $\mathrm{Ag}$ & -0.020475 & 1.213580 & -6.133199 \\
\hline $\mathrm{Ag}$ & 10.633781 & 1.246795 & -3.047499 \\
\hline $\mathrm{Ag}$ & -7.956102 & 1.246795 & 7.685375 \\
\hline $\mathrm{Ag}$ & 10.633781 & 1.246795 & 3.047499 \\
\hline $\mathrm{Ag}$ & -2.677679 & 1.246795 & 10.732874 \\
\hline $\mathrm{Ag}$ & -7.956102 & 1.246795 & -7.685375 \\
\hline $\mathrm{Ag}$ & -2.677679 & 1.246795 & -10.732874 \\
\hline $\mathrm{Ag}$ & 0.000000 & 0.986107 & 0.000000 \\
\hline $\mathrm{Ag}$ & 5.301928 & 1.221224 & 0.000000 \\
\hline $\mathrm{Ag}$ & -2.650964 & 1.221224 & 4.591604 \\
\hline $\mathrm{Ag}$ & -2.650964 & 1.221224 & -4.591604 \\
\hline $\mathrm{Ag}$ & 13.377237 & 0.744213 & -4.506497 \\
\hline $\mathrm{Ag}$ & -10.591360 & 0.744213 & 9.331778 \\
\hline
\end{tabular}

\begin{tabular}{|c|c|c|c|}
\hline $\mathrm{Ag}$ & 13.377237 & 0.744213 & 4.506497 \\
\hline $\mathrm{Ag}$ & -2.785877 & 0.744213 & 13.838275 \\
\hline $\mathrm{Ag}$ & -10.591360 & 0.744213 & -9.331778 \\
\hline $\mathrm{Ag}$ & -2.785877 & 0.744213 & -13.838275 \\
\hline $\mathrm{Ag}$ & 10.604750 & 1.192095 & 0.000000 \\
\hline $\mathrm{Ag}$ & -5.302375 & 1.192095 & 9.183983 \\
\hline $\mathrm{Ag}$ & -5.302375 & 1.192095 & -9.183983 \\
\hline $\mathrm{Ag}$ & 7.970762 & 1.195784 & -1.526104 \\
\hline $\mathrm{Ag}$ & -5.307026 & 1.195784 & 6.139831 \\
\hline $\mathrm{Ag}$ & 7.970762 & 1.195784 & 1.526104 \\
\hline $\mathrm{Ag}$ & -2.663737 & 1.195784 & 7.665935 \\
\hline $\mathrm{Ag}$ & -5.307026 & 1.195784 & -6.139831 \\
\hline $\mathrm{Ag}$ & -2.663737 & 1.195784 & -7.665935 \\
\hline $\mathrm{Ag}$ & 13.381081 & 0.722624 & -1.505266 \\
\hline $\mathrm{Ag}$ & -7.994139 & 0.722624 & 10.835723 \\
\hline $\mathrm{Ag}$ & 13.381081 & 0.722624 & 1.505266 \\
\hline $\mathrm{Ag}$ & -5.386942 & 0.722624 & 12.340989 \\
\hline $\mathrm{Ag}$ & -7.994139 & 0.722624 & -10.835723 \\
\hline $\mathrm{Ag}$ & -5.386942 & 0.722624 & -12.340989 \\
\hline $\mathrm{Ag}$ & 2.632687 & 1.203998 & 4.559948 \\
\hline $\mathrm{Ag}$ & 2.632687 & 1.203998 & -4.559948 \\
\hline $\mathrm{Ag}$ & -5.265374 & 1.203998 & 0.000000 \\
\hline $\mathrm{Ag}$ & 2.608606 & 1.238807 & 7.620201 \\
\hline $\mathrm{Ag}$ & 5.294985 & 1.238807 & 6.069220 \\
\hline $\mathrm{Ag}$ & 2.608606 & 1.238807 & -7.620201 \\
\hline $\mathrm{Ag}$ & -7.903591 & 1.238807 & -1.550982 \\
\hline $\mathrm{Ag}$ & 5.294985 & 1.238807 & -6.069220 \\
\hline $\mathrm{Ag}$ & -7.903591 & 1.238807 & 1.550982 \\
\hline $\mathrm{Ag}$ & 2.586859 & 1.232308 & 10.659570 \\
\hline $\mathrm{Ag}$ & 7.938029 & 1.232308 & 7.570071 \\
\hline $\mathrm{Ag}$ & 2.586859 & 1.232308 & -10.659570 \\
\hline $\mathrm{Ag}$ & -10.524888 & 1.232308 & -3.089499 \\
\hline $\mathrm{Ag}$ & 7.938029 & 1.232308 & -7.570071 \\
\hline $\mathrm{Ag}$ & -10.524888 & 1.232308 & 3.089499 \\
\hline $\mathrm{Ag}$ & 5.252888 & 1.194784 & 9.098269 \\
\hline $\mathrm{Ag}$ & 5.252888 & 1.194784 & -9.098269 \\
\hline $\mathrm{Ag}$ & -10.505777 & 1.194784 & 0.000000 \\
\hline $\mathrm{Ag}$ & 2.554869 & 0.199030 & 13.731559 \\
\hline $\mathrm{Ag}$ & 10.614444 & 0.199030 & 9.078361 \\
\hline $\mathrm{Ag}$ & 2.554869 & 0.199030 & -13.731559 \\
\hline $\mathrm{Ag}$ & -13.169314 & 0.199030 & -4.653198 \\
\hline $\mathrm{Ag}$ & 10.614444 & 0.199030 & -9.078361 \\
\hline $\mathrm{Ag}$ & -13.169314 & 0.199030 & 4.653198 \\
\hline $\mathrm{Ag}$ & 5.182871 & 0.251160 & 12.158823 \\
\hline $\mathrm{Ag}$ & 7.938414 & 0.251160 & 10.567909 \\
\hline $\mathrm{Ag}$ & 5.182871 & 0.251160 & -12.158823 \\
\hline $\mathrm{Ag}$ & -13.121285 & 0.251160 & -1.590914 \\
\hline $\mathrm{Ag}$ & 7.938414 & 0.251160 & -10.567909 \\
\hline $\mathrm{Ag}$ & -13.121285 & 0.251160 & 1.590914 \\
\hline
\end{tabular}




\begin{tabular}{|c|c|c|c|c|c|c|c|}
\hline $\mathrm{H}$ & -1.895525 & 3.735312 & 5.063171 & $\mathrm{C}$ & -0.680402 & 4.778358 & -2.818113 \\
\hline $\mathrm{H}$ & -1.895525 & 3.735312 & -5.063171 & $\mathrm{C}$ & -5.043488 & 4.947005 & 5.593452 \\
\hline $\mathrm{H}$ & 2.752083 & 3.732729 & 5.059262 & $\mathrm{C}$ & -5.043488 & 4.947005 & -5.593452 \\
\hline $\mathrm{H}$ & 2.752083 & 3.732729 & -5.059262 & $\mathrm{H}$ & -5.804259 & 5.011337 & 6.375016 \\
\hline $\mathrm{H}$ & -3.600905 & 3.922864 & 6.843675 & $\mathrm{H}$ & -5.804259 & 5.011337 & -6.375016 \\
\hline $\mathrm{H}$ & -3.600905 & 3.922864 & -6.843675 & $\mathrm{C}$ & 5.115065 & 5.474178 & 3.326589 \\
\hline $\mathrm{H}$ & 4.407679 & 4.013925 & 6.860815 & $\mathrm{C}$ & 5.115065 & 5.474178 & -3.326589 \\
\hline $\mathrm{H}$ & 4.407679 & 4.013925 & -6.860815 & $\mathrm{C}$ & 6.069658 & 5.614264 & 4.341625 \\
\hline $\mathrm{H}$ & 5.530271 & 3.931102 & -1.339215 & $\mathrm{C}$ & 6.069658 & 5.614264 & -4.341625 \\
\hline $\mathrm{H}$ & 5.530271 & 3.931102 & 1.339215 & $\mathrm{C}$ & -4.307252 & 5.402066 & 3.318533 \\
\hline $\mathrm{H}$ & -4.672448 & 3.859610 & 1.339456 & $\mathrm{C}$ & -4.307252 & 5.402066 & -3.318533 \\
\hline $\mathrm{H}$ & -4.672448 & 3.859610 & -1.339456 & $\mathrm{C}$ & -5.280294 & 5.491789 & 4.321046 \\
\hline $\mathrm{C}$ & 4.675182 & 4.085752 & 0.691925 & $\mathrm{C}$ & -5.280294 & 5.491789 & -4.321046 \\
\hline $\mathrm{C}$ & 4.675182 & 4.085752 & -0.691925 & $\mathrm{C}$ & -0.264715 & 5.458801 & 4.042624 \\
\hline $\mathrm{C}$ & -3.826753 & 4.053162 & 0.690938 & $\mathrm{C}$ & -0.264715 & 5.458801 & -4.042624 \\
\hline $\mathrm{C}$ & -3.826753 & 4.053162 & -0.690938 & $\mathrm{C}$ & 1.097207 & 5.465841 & 4.039218 \\
\hline $\mathrm{C}$ & -2.850430 & 4.216187 & 4.841017 & $\mathrm{C}$ & 1.097207 & 5.465841 & -4.039218 \\
\hline $\mathrm{C}$ & -2.850430 & 4.216187 & -4.841017 & $\mathrm{H}$ & 6.991302 & 6.164591 & 4.139007 \\
\hline $\mathrm{C}$ & 3.687241 & 4.252416 & 4.843167 & $\mathrm{H}$ & 6.991302 & 6.164591 & -4.139007 \\
\hline $\mathrm{C}$ & 3.687241 & 4.252416 & -4.843167 & $\mathrm{H}$ & 5.287407 & 5.954192 & 2.362463 \\
\hline $\mathrm{C}$ & 4.624687 & 4.417369 & 5.868546 & $\mathrm{H}$ & 5.287407 & 5.954192 & -2.362463 \\
\hline $\mathrm{C}$ & 4.624687 & 4.417369 & -5.868546 & $\mathrm{H}$ & -0.924017 & 5.929959 & 4.765223 \\
\hline $\mathrm{C}$ & -3.810924 & 4.333997 & 5.854128 & $\mathrm{H}$ & -0.924017 & 5.929959 & -4.765223 \\
\hline $\mathrm{C}$ & -3.810924 & 4.333997 & -5.854128 & $\mathrm{H}$ & 1.753796 & 5.942857 & 4.760250 \\
\hline $\mathrm{C}$ & 3.330968 & 4.319916 & -1.145430 & $\mathrm{H}$ & 1.753796 & 5.942857 & -4.760250 \\
\hline $\mathrm{C}$ & 3.330968 & 4.319916 & 1.145430 & $\mathrm{H}$ & -4.485105 & 5.887515 & 2.358560 \\
\hline $\mathrm{C}$ & -2.489768 & 4.320487 & 1.144094 & $\mathrm{H}$ & -4.485105 & 5.887515 & -2.358560 \\
\hline $\mathrm{C}$ & -2.489768 & 4.320487 & -1.144094 & $\mathrm{H}$ & -6.220156 & 6.008118 & 4.112423 \\
\hline $\mathrm{N}$ & 0.419105 & 4.407650 & 2.065394 & $\mathrm{H}$ & -6.220156 & 6.008118 & -4.112423 \\
\hline $\mathrm{N}$ & 0.419105 & 4.407650 & -2.065394 & & & & \\
\hline $\mathrm{N}$ & 2.550977 & 4.386455 & 0.000000 & \multicolumn{4}{|c|}{ S8-Benzene Dimer } \\
\hline $\mathrm{N}$ & -1.712154 & 4.410620 & 0.000000 & \multicolumn{4}{|c|}{$\mathrm{E}=-147.61618987 \mathrm{eV}$} \\
\hline $\mathrm{H}$ & -0.704076 & 4.550891 & 0.000000 & $\mathrm{H}$ & 0.965485 & -0.839188 & 2.188888 \\
\hline $\mathrm{C}$ & 2.884511 & 4.585897 & 2.468871 & $\mathrm{C}$ & 0.436542 & -0.932293 & 1.236708 \\
\hline $\mathrm{C}$ & 2.884511 & 4.585897 & -2.468871 & $\mathrm{C}$ & -0.943494 & -1.189527 & 1.222021 \\
\hline $\mathrm{C}$ & -2.048002 & 4.582131 & 2.470076 & $\mathrm{H}$ & -1.489074 & -1.298908 & 2.162880 \\
\hline $\mathrm{C}$ & -2.048002 & 4.582131 & -2.470076 & $\mathrm{C}$ & -1.623784 & -1.302856 & -0.000680 \\
\hline $\mathrm{H}$ & 1.539076 & 4.502951 & 0.000000 & $\mathrm{H}$ & -2.698982 & -1.500725 & -0.012122 \\
\hline $\mathrm{C}$ & 3.911297 & 4.760995 & 3.541338 & $\mathrm{C}$ & -0.922975 & -1.158500 & -1.208889 \\
\hline $\mathrm{C}$ & 3.911297 & 4.760995 & -3.541338 & $\mathrm{H}$ & -1.452549 & -1.243432 & -2.161353 \\
\hline $\mathrm{C}$ & -3.080561 & 4.729295 & 3.539774 & $\mathrm{C}$ & 0.456923 & -0.901190 & -1.193919 \\
\hline $\mathrm{C}$ & -3.080561 & 4.729295 & -3.539774 & $\mathrm{H}$ & 1.001834 & -0.783792 & -2.134307 \\
\hline $\mathrm{C}$ & 5.835045 & 5.079115 & 5.617818 & $\mathrm{C}$ & 1.136458 & -0.787976 & 0.028824 \\
\hline $\mathrm{C}$ & 5.835045 & 5.079115 & -5.617818 & $\mathrm{H}$ & 2.209793 & -0.580920 & 0.040502 \\
\hline $\mathrm{H}$ & 6.579345 & 5.187666 & 6.409658 & $\mathrm{H}$ & 1.553628 & 4.233294 & 2.161717 \\
\hline $\mathrm{H}$ & 6.579345 & 5.187666 & -6.409658 & $\mathrm{C}$ & 1.023484 & 4.152424 & 1.209115 \\
\hline $\mathrm{C}$ & 1.515570 & 4.783503 & 2.815636 & $\mathrm{C}$ & -0.357054 & 3.899409 & 1.193669 \\
\hline $\mathrm{C}$ & 1.515570 & 4.783503 & -2.815636 & $\mathrm{H}$ & -0.901908 & 3.780595 & 2.133946 \\
\hline $\mathrm{C}$ & -0.680402 & 4.778358 & 2.818113 & $\mathrm{C}$ & -1.036919 & 3.792425 & -0.029319 \\
\hline
\end{tabular}




$\begin{array}{lccc}\mathrm{H} & -2.110367 & 3.588855 & -0.041031 \\ \mathrm{C} & -0.336995 & 3.938023 & -1.237017 \\ \mathrm{H} & -0.866234 & 3.849806 & -2.189227 \\ \mathrm{C} & 1.043533 & 4.191417 & -1.221984 \\ \mathrm{H} & 1.589460 & 4.302948 & -2.162577 \\ \mathrm{C} & 1.723888 & 4.297748 & 0.001163 \\ \mathrm{H} & 2.799327 & 4.492364 & 0.013014\end{array}$

S9-2H-TPP

$\begin{array}{lccc}\mathrm{C} & 5.503858 & 5.538833 & -0.011872 \\ \mathrm{H} & 2.897836 & 4.358176 & -1.890858 \\ \mathrm{H} & 4.353843 & 2.951491 & 1.910021 \\ \mathrm{H} & 4.662405 & 6.120333 & -1.923896 \\ \mathrm{H} & 6.108287 & 4.723348 & 1.904178 \\ \mathrm{H} & 6.274368 & 6.313572 & -0.019994 \\ \mathrm{C} & 3.508973 & -3.535430 & 0.009818 \\ \mathrm{C} & 3.608055 & -4.440097 & -1.065809 \\ \mathrm{C} & 4.425488 & -3.650022 & 1.073830 \\ \mathrm{C} & 4.597645 & -5.432205 & -1.078128 \\ \mathrm{C} & 5.413301 & -4.644195 & 1.065277 \\ \mathrm{C} & 5.503858 & -5.538833 & -0.011872 \\ \mathrm{H} & 2.897836 & -4.358176 & -1.890858 \\ \mathrm{H} & 4.353843 & -2.951491 & 1.910021 \\ \mathrm{H} & 4.662405 & -6.120333 & -1.923896 \\ \mathrm{H} & 6.108287 & -4.723348 & 1.904178 \\ \mathrm{H} & 6.274368 & -6.313572 & -0.019994 \\ \mathrm{C} & -3.508973 & 3.535430 & 0.009818 \\ \mathrm{C} & -3.608055 & 4.440097 & -1.065809 \\ \mathrm{C} & -4.425488 & 3.650022 & 1.073830 \\ \mathrm{C} & -4.597645 & 5.432205 & -1.078128 \\ \mathrm{C} & -5.413301 & 4.644195 & 1.065277 \\ \mathrm{C} & -5.503858 & 5.538833 & -0.011872 \\ \mathrm{H} & -2.897836 & 4.358176 & -1.890858 \\ \mathrm{H} & -4.353843 & 2.951491 & 1.910021 \\ \mathrm{H} & -4.662405 & 6.120333 & -1.923896 \\ \mathrm{H} & -6.108287 & 4.723348 & 1.904178 \\ \mathrm{H} & -6.274368 & 6.313572 & -0.019994 \\ \mathrm{C} & -3.508973 & -3.535430 & 0.009818 \\ \mathrm{C} & -3.608055 & -4.440097 & -1.065809 \\ \mathrm{C} & -4.425488 & -3.650022 & 1.073830 \\ \mathrm{C} & -4.597645 & -5.432205 & -1.078128 \\ \mathrm{C} & -5.413301 & -4.644195 & 1.065277 \\ \mathrm{H} & -5.503858 & -5.538833 & -0.011872 \\ & -2.897836 & -4.358176 & -1.890858 \\ \mathrm{H} & -4.662405 & -6.120333 & -1.923896 \\ \mathrm{H} & -6.108287 & -4.723348 & 1.904178 \\ & -6.313572 & -0.019994\end{array}$

S10- Cu(111)-166 Surface Cluster

$\begin{array}{cccc}\mathrm{E}=-429.86498153 \mathrm{eV} & \text { Symmetry: } \mathrm{C}_{\mathrm{s}} \\ \mathrm{Cu} & 8.105765 & -1.142575 & 6.381640 \\ \mathrm{Cu} & 8.105765 & -1.142575 & -6.381640 \\ \mathrm{Cu} & 1.473780 & -1.142575 & 10.210618 \\ \mathrm{Cu} & 1.473780 & -1.142575 & -10.210618 \\ \mathrm{Cu} & -9.579545 & -1.142575 & -3.828978 \\ \mathrm{Cu} & -9.579545 & -1.142575 & 3.828978 \\ \mathrm{Cu} & 5.895106 & -1.142573 & 7.657964\end{array}$




\begin{tabular}{|c|c|c|c|c|c|c|c|}
\hline $\mathrm{Cu}$ & 5.895106 & -1.142573 & -7.657964 & $\mathrm{Cu}$ & -2.947552 & -1.142563 & 7.657965 \\
\hline $\mathrm{Cu}$ & 3.684439 & -1.142573 & 8.934294 & $\mathrm{Cu}$ & -2.947552 & -1.142563 & -7.657965 \\
\hline $\mathrm{Cu}$ & 3.684439 & -1.142573 & -8.934294 & $\mathrm{Cu}$ & -5.158216 & -1.142563 & 6.381637 \\
\hline $\mathrm{Cu}$ & -9.579545 & -1.142573 & -1.276329 & $\mathrm{Cu}$ & -5.158216 & -1.142563 & -6.381637 \\
\hline $\mathrm{Cu}$ & -9.579545 & -1.142573 & 1.276329 & $\mathrm{Cu}$ & 3.684441 & -1.142562 & 1.276321 \\
\hline $\mathrm{Cu}$ & 5.895105 & -1.142571 & 5.105304 & $\mathrm{Cu}$ & 3.684441 & -1.142562 & -1.276321 \\
\hline $\mathrm{Cu}$ & 5.895105 & -1.142571 & -5.105304 & $\mathrm{Cu}$ & -0.736894 & -1.142562 & 3.828980 \\
\hline $\mathrm{Cu}$ & 1.473770 & -1.142571 & 7.657963 & $\mathrm{Cu}$ & -0.736894 & -1.142562 & -3.828980 \\
\hline $\mathrm{Cu}$ & 1.473770 & -1.142571 & -7.657963 & $\mathrm{Cu}$ & -2.947547 & -1.142562 & 2.552659 \\
\hline $\mathrm{Cu}$ & -7.368876 & -1.142571 & -2.552659 & $\mathrm{Cu}$ & -2.947547 & -1.142562 & -2.552659 \\
\hline $\mathrm{Cu}$ & -7.368876 & -1.142571 & 2.552659 & $\mathrm{Cu}$ & 10.316427 & -1.142561 & 0.000000 \\
\hline $\mathrm{Cu}$ & 10.316433 & -1.142569 & -5.105310 & $\mathrm{Cu}$ & -5.158214 & -1.142561 & 8.934288 \\
\hline $\mathrm{Cu}$ & 10.316433 & -1.142569 & 5.105310 & $\mathrm{Cu}$ & -5.158214 & -1.142561 & -8.934288 \\
\hline $\mathrm{Cu}$ & 3.684438 & -1.142569 & 6.381633 & $\mathrm{Cu}$ & 5.895100 & -1.142560 & 0.000000 \\
\hline $\mathrm{Cu}$ & 3.684438 & -1.142569 & -6.381633 & $\mathrm{Cu}$ & 1.473778 & -1.142560 & 0.000000 \\
\hline $\mathrm{Cu}$ & -0.736888 & -1.142569 & 11.486948 & $\mathrm{Cu}$ & -0.736889 & -1.142560 & 1.276329 \\
\hline $\mathrm{Cu}$ & -0.736888 & -1.142569 & -11.486948 & $\mathrm{Cu}$ & -0.736889 & -1.142560 & -1.276329 \\
\hline $\mathrm{Cu}$ & -7.368876 & -1.142569 & 0.000000 & $\mathrm{Cu}$ & -2.947550 & -1.142560 & 5.105306 \\
\hline $\mathrm{Cu}$ & -9.579545 & -1.142569 & 6.381637 & $\mathrm{Cu}$ & -2.947550 & -1.142560 & -5.105306 \\
\hline $\mathrm{Cu}$ & -9.579545 & -1.142569 & -6.381637 & $\mathrm{Cu}$ & 8.842651 & 0.941652 & 7.657964 \\
\hline $\mathrm{Cu}$ & 3.684442 & -1.142567 & 3.828982 & $\mathrm{Cu}$ & 8.842651 & 0.941652 & -7.657964 \\
\hline $\mathrm{Cu}$ & 3.684442 & -1.142567 & -3.828982 & $\mathrm{Cu}$ & 2.210666 & 0.941652 & 11.486943 \\
\hline $\mathrm{Cu}$ & 1.473774 & -1.142567 & 5.105311 & $\mathrm{Cu}$ & 2.210666 & 0.941652 & -11.486943 \\
\hline $\mathrm{Cu}$ & 1.473774 & -1.142567 & -5.105311 & $\mathrm{Cu}$ & -11.053317 & 0.941652 & -3.828978 \\
\hline $\mathrm{Cu}$ & -5.158216 & -1.142567 & -1.276329 & $\mathrm{Cu}$ & -11.053317 & 0.941652 & 3.828978 \\
\hline $\mathrm{Cu}$ & -5.158216 & -1.142567 & 1.276329 & $\mathrm{Cu}$ & 6.631992 & 0.941654 & 8.934289 \\
\hline $\mathrm{Cu}$ & 8.105764 & -1.142566 & -3.828979 & $\mathrm{Cu}$ & 6.631992 & 0.941654 & -8.934289 \\
\hline $\mathrm{Cu}$ & 8.105764 & -1.142566 & 3.828979 & $\mathrm{Cu}$ & 4.421325 & 0.941654 & 10.210618 \\
\hline $\mathrm{Cu}$ & -0.736889 & -1.142566 & 8.934287 & $\mathrm{Cu}$ & 4.421325 & 0.941654 & -10.210618 \\
\hline $\mathrm{Cu}$ & -0.736889 & -1.142566 & -8.934287 & $\mathrm{Cu}$ & -11.053317 & 0.941654 & -1.276329 \\
\hline $\mathrm{Cu}$ & -7.368876 & -1.142566 & 5.105308 & $\mathrm{Cu}$ & -11.053317 & 0.941654 & 1.276329 \\
\hline $\mathrm{Cu}$ & -7.368876 & -1.142566 & -5.105308 & $\mathrm{Cu}$ & 6.631996 & 0.941656 & 6.381637 \\
\hline $\mathrm{Cu}$ & 10.316432 & -1.142565 & -2.552650 & $\mathrm{Cu}$ & 6.631996 & 0.941656 & -6.381637 \\
\hline $\mathrm{Cu}$ & 10.316432 & -1.142565 & 2.552650 & $\mathrm{Cu}$ & 2.210661 & 0.941656 & 8.934296 \\
\hline $\mathrm{Cu}$ & -2.947556 & -1.142565 & 10.210617 & $\mathrm{Cu}$ & 2.210661 & 0.941656 & -8.934296 \\
\hline $\mathrm{Cu}$ & -2.947556 & -1.142565 & -10.210617 & $\mathrm{Cu}$ & -8.842658 & 0.941656 & -2.552659 \\
\hline $\mathrm{Cu}$ & -7.368876 & -1.142565 & 7.657967 & $\mathrm{Cu}$ & -8.842658 & 0.941656 & 2.552659 \\
\hline $\mathrm{Cu}$ & -7.368876 & -1.142565 & -7.657967 & $\mathrm{Cu}$ & 11.053319 & 0.941658 & -6.381635 \\
\hline $\mathrm{Cu}$ & 5.895101 & -1.142564 & 2.552657 & $\mathrm{Cu}$ & 11.053319 & 0.941658 & 6.381635 \\
\hline $\mathrm{Cu}$ & 5.895101 & -1.142564 & -2.552657 & $\mathrm{Cu}$ & 4.421329 & 0.941658 & 7.657966 \\
\hline $\mathrm{Cu}$ & -0.736884 & -1.142564 & 6.381636 & $\mathrm{Cu}$ & 4.421329 & 0.941658 & -7.657966 \\
\hline $\mathrm{Cu}$ & -0.736884 & -1.142564 & -6.381636 & $\mathrm{Cu}$ & -0.000002 & 0.941658 & 12.763272 \\
\hline $\mathrm{Cu}$ & -5.158216 & -1.142564 & 3.828978 & $\mathrm{Cu}$ & -0.000002 & 0.941658 & -12.763272 \\
\hline $\mathrm{Cu}$ & -5.158216 & -1.142564 & -3.828978 & $\mathrm{Cu}$ & -8.842658 & 0.941658 & 0.000000 \\
\hline $\mathrm{Cu}$ & 8.105768 & -1.142563 & 1.276328 & $\mathrm{Cu}$ & -11.053317 & 0.941658 & 6.381637 \\
\hline $\mathrm{Cu}$ & 8.105768 & -1.142563 & -1.276328 & $\mathrm{Cu}$ & -11.053317 & 0.941658 & -6.381637 \\
\hline $\mathrm{Cu}$ & 1.473774 & -1.142563 & 2.552651 & $\mathrm{Cu}$ & 4.421328 & 0.941660 & 5.105306 \\
\hline $\mathrm{Cu}$ & 1.473774 & -1.142563 & -2.552651 & $\mathrm{Cu}$ & 4.421328 & 0.941660 & -5.105306 \\
\hline $\mathrm{Cu}$ & -2.947547 & -1.142563 & 0.000000 & $\mathrm{Cu}$ & 2.210661 & 0.941660 & 6.381635 \\
\hline
\end{tabular}




\begin{tabular}{|c|c|c|c|c|c|c|c|}
\hline $\mathrm{Cu}$ & 2.210661 & 0.941660 & -6.381635 & $\mathrm{Cu}$ & 2.210664 & 0.941668 & 1.276323 \\
\hline $\mathrm{Cu}$ & -6.631989 & 0.941660 & -1.276329 & $\mathrm{Cu}$ & 2.210664 & 0.941668 & -1.276323 \\
\hline $\mathrm{Cu}$ & -6.631989 & 0.941660 & 1.276329 & $\mathrm{Cu}$ & -0.000004 & 0.941668 & 2.552653 \\
\hline $\mathrm{Cu}$ & 8.842655 & 0.941661 & -5.105312 & $\mathrm{Cu}$ & -0.000004 & 0.941668 & -2.552653 \\
\hline $\mathrm{Cu}$ & 8.842655 & 0.941661 & 5.105312 & $\mathrm{Cu}$ & -2.210660 & 0.941668 & 1.276329 \\
\hline $\mathrm{Cu}$ & 0.000003 & 0.941661 & 10.210620 & $\mathrm{Cu}$ & -2.210660 & 0.941668 & -1.276329 \\
\hline $\mathrm{Cu}$ & 0.000003 & 0.941661 & -10.210620 & $\mathrm{Cu}$ & -4.421329 & 0.941668 & 7.657967 \\
\hline $\mathrm{Cu}$ & -8.842658 & 0.941661 & 5.105308 & $\mathrm{Cu}$ & -4.421329 & 0.941668 & -7.657967 \\
\hline $\mathrm{Cu}$ & -8.842658 & 0.941661 & -5.105308 & $\mathrm{Cu}$ & 4.421323 & 0.941669 & 0.000000 \\
\hline $\mathrm{Cu}$ & 11.053323 & 0.941662 & -3.828983 & $\mathrm{Cu}$ & -2.210661 & 0.941669 & 3.828978 \\
\hline $\mathrm{Cu}$ & 11.053323 & 0.941662 & 3.828983 & $\mathrm{Cu}$ & -2.210661 & 0.941669 & -3.828978 \\
\hline $\mathrm{Cu}$ & -2.210665 & 0.941662 & 11.486950 & $\mathrm{Cu}$ & 0.000000 & 0.941670 & 0.000000 \\
\hline $\mathrm{Cu}$ & -2.210665 & 0.941662 & -11.486950 & & & & \\
\hline $\mathrm{Cu}$ & -8.842658 & 0.941662 & 7.657967 & \multicolumn{4}{|c|}{$\underline{\text { S11-Ag(111)-166 Surface Cluster }}$} \\
\hline $\mathrm{Cu}$ & -8.842658 & 0.941662 & -7.657967 & \multicolumn{3}{|c|}{$\mathrm{E}=-298.19021653 \mathrm{eV}$} & ymmetry: $\mathrm{C}_{\mathrm{s}}$ \\
\hline $\mathrm{Cu}$ & 6.631987 & 0.941663 & -3.828981 & $\mathrm{Ag}$ & 1.668103 & -1.641278 & 0.000000 \\
\hline $\mathrm{Cu}$ & 6.631987 & 0.941663 & 3.828981 & $\mathrm{Ag}$ & -0.834052 & -1.641278 & 1.444620 \\
\hline $\mathrm{Cu}$ & 0.000002 & 0.941663 & 7.657960 & $\mathrm{Ag}$ & -0.834052 & -1.641278 & -1.444620 \\
\hline $\mathrm{Cu}$ & 0.000002 & 0.941663 & -7.657960 & $\mathrm{Ag}$ & 9.174555 & -1.641277 & -4.333848 \\
\hline $\mathrm{Cu}$ & -6.631989 & 0.941663 & 3.828978 & $\mathrm{Ag}$ & -8.340500 & -1.641277 & 5.778474 \\
\hline $\mathrm{Cu}$ & -6.631989 & 0.941663 & -3.828978 & $\mathrm{Ag}$ & 9.174555 & -1.641277 & 4.333848 \\
\hline $\mathrm{Cu}$ & 2.210665 & 0.941664 & 3.828984 & $\mathrm{Ag}$ & -0.834055 & -1.641277 & 10.112322 \\
\hline $\mathrm{Cu}$ & 2.210665 & 0.941664 & -3.828984 & $\mathrm{Ag}$ & -8.340500 & -1.641277 & -5.778474 \\
\hline $\mathrm{Cu}$ & -4.421330 & 0.941664 & 0.000000 & $\mathrm{Ag}$ & -0.834055 & -1.641277 & -10.112322 \\
\hline $\mathrm{Cu}$ & 8.842655 & 0.941665 & -2.552652 & $\mathrm{Ag}$ & 11.676708 & -1.641274 & -5.778467 \\
\hline $\mathrm{Cu}$ & 8.842655 & 0.941665 & 2.552652 & $\mathrm{Ag}$ & -10.842654 & -1.641274 & 7.223092 \\
\hline $\mathrm{Cu}$ & 4.421332 & 0.941665 & 2.552654 & $\mathrm{Ag}$ & 11.676708 & -1.641274 & 5.778467 \\
\hline $\mathrm{Cu}$ & 4.421332 & 0.941665 & -2.552654 & $\mathrm{Ag}$ & -0.834054 & -1.641274 & 13.001559 \\
\hline $\mathrm{Cu}$ & -0.000003 & 0.941665 & 5.105313 & $\mathrm{Ag}$ & -10.842654 & -1.641274 & -7.223092 \\
\hline $\mathrm{Cu}$ & -0.000003 & 0.941665 & -5.105313 & $\mathrm{Ag}$ & -0.834054 & -1.641274 & -13.001559 \\
\hline $\mathrm{Cu}$ & -2.210666 & 0.941665 & 8.934289 & $\mathrm{Ag}$ & 4.170256 & -1.641274 & -1.444616 \\
\hline $\mathrm{Cu}$ & -2.210666 & 0.941665 & -8.934289 & $\mathrm{Ag}$ & -3.336202 & -1.641274 & 2.889240 \\
\hline $\mathrm{Cu}$ & -4.421330 & 0.941665 & 2.552659 & $\mathrm{Ag}$ & 4.170256 & -1.641274 & 1.444616 \\
\hline $\mathrm{Cu}$ & -4.421330 & 0.941665 & -2.552659 & $\mathrm{Ag}$ & -0.834054 & -1.641274 & 4.333856 \\
\hline $\mathrm{Cu}$ & -6.631989 & 0.941665 & 6.381637 & $\mathrm{Ag}$ & -3.336202 & -1.641274 & -2.889240 \\
\hline $\mathrm{Cu}$ & -6.631989 & 0.941665 & -6.381637 & $\mathrm{Ag}$ & -0.834054 & -1.641274 & -4.333856 \\
\hline $\mathrm{Cu}$ & 11.053313 & 0.941666 & -1.276327 & $\mathrm{Ag}$ & 9.174558 & -1.641273 & -1.444606 \\
\hline $\mathrm{Cu}$ & 11.053313 & 0.941666 & 1.276327 & $\mathrm{Ag}$ & -5.838345 & -1.641273 & 7.223097 \\
\hline $\mathrm{Cu}$ & -4.421325 & 0.941666 & 10.210614 & $\mathrm{Ag}$ & 9.174558 & -1.641273 & 1.444606 \\
\hline $\mathrm{Cu}$ & -4.421325 & 0.941666 & -10.210614 & $\mathrm{Ag}$ & -3.336213 & -1.641273 & 8.667703 \\
\hline $\mathrm{Cu}$ & -6.631989 & 0.941666 & 8.934286 & $\mathrm{Ag}$ & -5.838345 & -1.641273 & -7.223097 \\
\hline $\mathrm{Cu}$ & -6.631989 & 0.941666 & -8.934286 & $\mathrm{Ag}$ & -3.336213 & -1.641273 & -8.667703 \\
\hline $\mathrm{Cu}$ & 6.631991 & 0.941667 & 1.276330 & $\mathrm{Ag}$ & 6.672402 & -1.641271 & -2.889230 \\
\hline $\mathrm{Cu}$ & 6.631991 & 0.941667 & -1.276330 & $\mathrm{Ag}$ & -5.838348 & -1.641271 & 4.333854 \\
\hline $\mathrm{Cu}$ & -2.210662 & 0.941667 & 6.381638 & $\mathrm{Ag}$ & 6.672402 & -1.641271 & 2.889230 \\
\hline $\mathrm{Cu}$ & -2.210662 & 0.941667 & -6.381638 & $\mathrm{Ag}$ & -0.834054 & -1.641271 & 7.223084 \\
\hline $\mathrm{Cu}$ & -4.421330 & 0.941667 & 5.105308 & $\mathrm{Ag}$ & -5.838348 & -1.641271 & -4.333854 \\
\hline $\mathrm{Cu}$ & -4.421330 & 0.941667 & -5.105308 & $\mathrm{Ag}$ & -0.834054 & -1.641271 & -7.223084 \\
\hline $\mathrm{Cu}$ & 8.842659 & 0.941668 & 0.000000 & $\mathrm{Ag}$ & 11.676697 & -1.641269 & -2.889229 \\
\hline
\end{tabular}




\begin{tabular}{|c|c|c|c|}
\hline g & -8.340494 & -1.641269 & 8.667702 \\
\hline$\sigma$ & 11.676697 & -1.641269 & 2.889229 \\
\hline & -3.336203 & -1.641269 & 11.556930 \\
\hline$g$ & -8.340494 & -1.641269 & -8.667702 \\
\hline & -3.336203 & -1.641269 & 56930 \\
\hline$g$ & 6.672412 & -1.641266 & 0.000000 \\
\hline g & -3.336206 & -1.6 & 5.778479 \\
\hline & -3.336206 & -1.6 & -5.778479 \\
\hline & 11.676702 & -1.6 & 0.000000 \\
\hline & -5.838351 & -1.6 & 10.1 \\
\hline & -5.8 & -1.6 & -10.1 \\
\hline & 1.668100 & -1.6 & 2.8 \\
\hline & 1.66 & & -2.8 \\
\hline & -3.336201 & -1.6 & 0.000000 \\
\hline & 1.668 & $-1 .($ & 477 \\
\hline & 4.17 & $-1 .($ & 4.3 \\
\hline & 1.6 & -1.6 & -5.7 \\
\hline g & -5.8 & -1. & -1.4 \\
\hline & 4.17 & -1.6 & 3858 \\
\hline & -5.8 & -1. & \\
\hline & 1.66 & -1.6 & 711 \\
\hline & $6.6^{\prime}$ & $-1 .($ & \\
\hline & 1.66 & -1.6 & 711 \\
\hline & -8.3 & -1.6 & -2.8 \\
\hline & 6.67 & $-1 .($ & 3472 \\
\hline & -8.3 & -1. & 2.8 \\
\hline$g$ & 4.1 & -1.6 & 7.2 \\
\hline & $4.1^{\prime}$ & -1.6 & 3091 \\
\hline & -8.3 & -1. & 0000 \\
\hline & 1.6 & -1.6 & 11.5 \\
\hline & $9.1^{\prime}$ & -1.6 & 7.22 \\
\hline & 1.6 & -1.6 & -11.5 \\
\hline$g$ & -10.8 & 250 & -4.3 \\
\hline & 9.17 & -1.6 & -7.22 \\
\hline$\sigma$ & -10.8 & -1. & \\
\hline 0 & 4.17 & -1.6 & 10.112325 \\
\hline$g$ & $6.6^{\circ}$ & -1.6 & 8.6 \\
\hline g & 4.17 & -1.6 & -10.112325 \\
\hline & -10.8 & 1246 & -1.444620 \\
\hline Ag & $6.6^{\circ}$ & -1.6 & -8.667705 \\
\hline & -10.842656 & -1.641246 & 1.444620 \\
\hline$A g$ & 13.1 & 2179 & -7.543353 \\
\hline 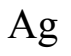 & -13.1 & 179 & 7.647630 \\
\hline Aq & 13.1 & 2179 & 7.5 \\
\hline $\mathrm{Ag}$ & -0.060204 & 0.422179 & 15.190983 \\
\hline 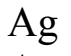 & -13.125675 & 0.422179 & -7.647630 \\
\hline $\mathrm{Ag}$ & -0.060204 & 0.422179 & -15.190983 \\
\hline & 7.967890 & 1.220392 & -4.553228 \\
\hline As & -7.927156 & 1.220392 & 4.623781 \\
\hline
\end{tabular}

\begin{tabular}{|c|c|c|c|}
\hline $\mathrm{Ag}$ & 7.967890 & 1.220392 & 4 \\
\hline $\mathrm{Ag}$ & -0.040734 & 1.220392 & 9.177009 \\
\hline & -7.927156 & 1.220392 & -4.623781 \\
\hline$g$ & -0.040734 & 1.220392 & -9.177009 \\
\hline & 2.652585 & 1.109313 & -1.525809 \\
\hline$g$ & -2.647682 & 1.109313 & 1.534302 \\
\hline & 2.652585 & 1.109313 & 1.525809 \\
\hline $\mathrm{g}$ & -0.004903 & 1.109313 & 3.060111 \\
\hline & -2.647682 & 1.109313 & -1.534302 \\
\hline g & -0.004903 & 1.109313 & -3.060111 \\
\hline$g$ & 10.586752 & 1.278114 & -6.048115 \\
\hline$g$ & -10.531197 & 1.278114 & 4339 \\
\hline $\mathrm{g}$ & 10.586752 & $1.27 \varepsilon$ & 115 \\
\hline$g$ & -0.055555 & 1.278114 & 12.192454 \\
\hline$g$ & -10.531197 & 1.27 & 4339 \\
\hline$g$ & -0.055555 & 1.278114 & -12.192454 \\
\hline $\mathrm{g}$ & 5.321744 & 1.213 & 8868 \\
\hline$g$ & -5.301269 & 1.213 & 331 \\
\hline$g$ & 5.321 & 1.213 & 368 \\
\hline g & -0.020475 & 1.21 & 199 \\
\hline $\mathrm{g}$ & -5.301269 & 1.213580 & 4331 \\
\hline $\mathrm{Ag}$ & -0.020 & 1.21 & 199 \\
\hline$g$ & 10.633781 & 1.246795 & 7499 \\
\hline $\mathrm{Ag}$ & -7.956102 & 1.246 & 375 \\
\hline $\mathrm{g}$ & 10.633781 & 1.246795 & 7499 \\
\hline $\mathrm{Ag}$ & -2.677679 & 1.246 & 2874 \\
\hline $\mathrm{g}$ & -7.956102 & 1.246 & 5375 \\
\hline $\mathrm{Ag}$ & -2.67 & 1.246 & 32874 \\
\hline $\mathrm{lg}$ & 0.00 & 0.98 & 000 \\
\hline $\mathrm{Ag}$ & 5.301928 & 1.221224 & 0000 \\
\hline $\mathrm{Ag}$ & -2.650964 & 1.221224 & 4.591604 \\
\hline $\mathrm{Ag}$ & -2.650964 & 1.221224 & -4.591604 \\
\hline $\mathrm{Ag}$ & 13.377237 & 0.744213 & -4.506497 \\
\hline $\mathrm{Ag}$ & -10.591360 & 0.744213 & 9.331778 \\
\hline $\mathrm{Ag}$ & 13.377237 & 0.744213 & 4.506497 \\
\hline $\mathrm{Ag}$ & -2.785877 & 0.744213 & 13.838275 \\
\hline $\mathrm{Ag}$ & -10.591360 & 0.744213 & -9.331778 \\
\hline $\mathrm{Ag}$ & -2.785877 & 0.744213 & -13.838275 \\
\hline 1 & 10.604750 & 1.192095 & 0.000000 \\
\hline $\mathrm{Ag}$ & -5.302375 & 1.192095 & 9.183983 \\
\hline $\mathrm{Ag}$ & -5.302375 & 1.192095 & -9.183983 \\
\hline $\mathrm{Ag}$ & 7.970762 & 1.195784 & -1.526104 \\
\hline $\mathrm{Ag}$ & -5.307026 & 1.195784 & 6.139831 \\
\hline $\mathrm{Ag}$ & 7.970762 & 1.195784 & 1.526104 \\
\hline $\mathrm{Ag}$ & -2.663737 & 1.195784 & 7.665935 \\
\hline $\mathrm{Ag}$ & -5.307026 & 1.195784 & -6.139831 \\
\hline $\mathrm{Ag}$ & -2.663737 & 1.195784 & -7.665935 \\
\hline $\mathrm{Ag}$ & 13.381081 & 0.722624 & -1.505266 \\
\hline $\mathrm{Ag}$ & -7.994139 & 0.722624 & 10.835723 \\
\hline
\end{tabular}




$\begin{array}{cccc}\mathrm{Ag} & 13.381081 & 0.722624 & 1.505266 \\ \mathrm{Ag} & -5.386942 & 0.722624 & 12.340989 \\ \mathrm{Ag} & -7.994139 & 0.722624 & -10.835723 \\ \mathrm{Ag} & -5.386942 & 0.722624 & -12.340989 \\ \mathrm{Ag} & 2.632687 & 1.203998 & 4.559948 \\ \mathrm{Ag} & 2.632687 & 1.203998 & -4.559948 \\ \mathrm{Ag} & -5.265374 & 1.203998 & 0.000000 \\ \mathrm{Ag} & 2.608606 & 1.238807 & 7.620201 \\ \mathrm{Ag} & 5.294985 & 1.238807 & 6.069220 \\ \mathrm{Ag} & 2.608606 & 1.238807 & -7.620201 \\ \mathrm{Ag} & -7.903591 & 1.238807 & -1.550982 \\ \mathrm{Ag} & 5.294985 & 1.238807 & -6.069220 \\ \mathrm{Ag} & -7.903591 & 1.238807 & 1.550982 \\ \mathrm{Ag} & 2.586859 & 1.232308 & 10.659570 \\ \mathrm{Ag} & 7.938029 & 1.232308 & 7.570071 \\ \mathrm{Ag} & 2.586859 & 1.232308 & -10.659570 \\ \mathrm{Ag} & -10.524888 & 1.232308 & -3.089499 \\ \mathrm{Ag} & 7.938029 & 1.232308 & -7.570071\end{array}$

$\begin{array}{lccc}\mathrm{Ag} & -10.524888 & 1.232308 & 3.089499 \\ \mathrm{Ag} & 5.252888 & 1.194784 & 9.098269 \\ \mathrm{Ag} & 5.252888 & 1.194784 & -9.098269 \\ \mathrm{Ag} & -10.505777 & 1.194784 & 0.000000 \\ \mathrm{Ag} & 2.554869 & 0.199030 & 13.731559 \\ \mathrm{Ag} & 10.614444 & 0.199030 & 9.078361 \\ \mathrm{Ag} & 2.554869 & 0.199030 & -13.731559 \\ \mathrm{Ag} & -13.169314 & 0.199030 & -4.653198 \\ \mathrm{Ag} & 10.614444 & 0.199030 & -9.078361 \\ \mathrm{Ag} & -13.169314 & 0.199030 & 4.653198 \\ \mathrm{Ag} & 5.182871 & 0.251160 & 12.158823 \\ \mathrm{Ag} & 7.938414 & 0.251160 & 10.567909 \\ \mathrm{Ag} & 5.182871 & 0.251160 & -12.158823 \\ \mathrm{Ag} & -13.121285 & 0.251160 & -1.590914 \\ \mathrm{Ag} & 7.938414 & 0.251160 & -10.567909 \\ \mathrm{Ag} & -13.121285 & 0.251160 & 1.59091\end{array}$




\section{References}

[1] te Velde, G.; Bickelhaupt, F. M.; Baerends, E. J.; Fonseca Guerra, C.; van Gisbergen, S. J. A.; Snijders, J. G.; Ziegler, T. Chemistry with ADF. J. Comput. Chem. 22, 931-967 (2001).

[2] Baerends, E. J.; Autschbach, J.; Bérces, A.; Bickelhaupt, F. M.; Bo, C.; Boerrigter, P. M.; Cavallo, L.; Chong, D. P.; Deng, L.; Dickson, R. M.; et al. ADF2010.01, SCM, Theoretical Chemistry, Vrije Universiteit, Amsterdam, The Netherlands, http://www.scm.com.

[3] Perdew, J. P.; Burke, K.; Wang, Y. Generalized Gradient Approximation for the ExchangeCorrelation Hole of a Many-Electron System. Phys. Rev. B 54, 16533-16539 (1996).

[4] Zhang, Y.; Yang, W. Comment on Generalized Gradient Approximation Made Simple. Phys. Rev. Lett. 80, 89 (1998).

[5] Perdew, J. P.; Burke, K.; Ernzerhof, M. Reply to Comment on Generalized Gradient Approximation Made Simple. Phys. Rev. Lett. 80, 891 (1998).

[6] Hammer, B.; Hansen, L. B.; Norskov, J. K. Improved Adsorption Energetics within DensityFunctional Theory using Revised Perdew-Burke-Ernzerhof Functionals. Phys. Rev. B 59, 74137421. (1999).

[7] Grimme, S.; Antony, J., Ehrlich, S.; Krieg, H. A consistent and accurate ab initio parameterization of density functional dispersion correction (DFT-D) for the 94 elements H-Pu. J. Chem. Phys. 132, 154104 (2010).

[8] Suh, I.; Ohta, H.; Waseda, Y. High-temperature thermal expansion of six metallic elements measured by dilatation method and X-ray diffraction. J. Mater. Sci. 23, 757-760 (1988).

[9] Pitoňák, M.; Neogrády, P.; Řezáč, J.; Jurečka, P.; Urban, M.; Hobza, P. Benzene Dimer: High-Level Wave Funtion and Density Functional Theory Calculations. 4, 1829-1834 (2008).

[10] Lomas, J. R.; Baddeley, C. J.; Tikhov, M. S.; Lambert, R M. Ethyne Cyclization to Benzene over Cu(110). Langmuir. 11, 3048-3053 (1995).

[11] (a) Lukas, S.; Witte, G.; Wöll, C. Adsorption of acenes on flat and vicinal Cu(111) surfaces: Step induced formation of lateral order. J. Chem. Phys. 114, 10123 (2001).

(b) Xi, M.; Yang, M. X.; Jo, S. K.; Bent, B. E.; Stevens, P. Benzene adsorption on $\mathrm{Cu}(111)$ :Formation of a stable bilayer. J. Chem. Phys. 101, 9122 (1994)

[12] Witte, G.; Lukas, S.; Bagus, P. S.; Wöll, C. Vacuum level alignment at organic/metal junctions: "Cushion" effect and the interface dipole. Appl. Phys. Lett. 87, 263502 (2005)

[13] Triguero, L.; Föhlisch, A.; Vaterlaein, P.; Hasselström, J.; Weinelt, M.; Petterson, L. G. M.; Luo, Y.; Agren, H.; Nilsson, A. Direct Measurement of Donation/Back-Donation in Unsaturated Hydrocarbon Bonding to Metals. J. Am. Chem. Soc. 122, 12310-12316 (2000). 
[14] Bickelhaupt, F. M.; Baerends, E. J. Kohn-Sham Density Functional Theory: Predicting and Understanding Chemistry. Rev. Comp. Chem. 15, 1-86 (2000).

[15] Hoffmann, R. A chemical and theoretical way to look at bonding on surfaces. Rev. Mod. Phys. 60, 601-628 (1988).

[16] Glassey, W. G.; Hoffmann, R. A Cinoaratuve Study of p(2x2)-CO/M(111), M=Pt,Cu,Al Chemisorption Systems. J. Phys. Chem. B 105, 3245-3260 (2001).

[17] Philipsen, P. H. T.; Baerends, E. J. The role of the Fermi surface in adsorbate-metal interaction: an energy decomposition analysis. J. Phys. Chem. B 110, 12470-12479 (2006).

[18] Glassey, W. G. Energy Partitioning Studies of CO and NO Chemisorption on the Pd(111) Surface. J. Phy. Chem. B 108, 5967-5979 (2004).

[19] Wiberg, K. B.; Rablen, P. R. Comparison of Atomic Charges Derived via Different Procedures. J. Comput. Chem. 14, 1504-1518 (1993). 